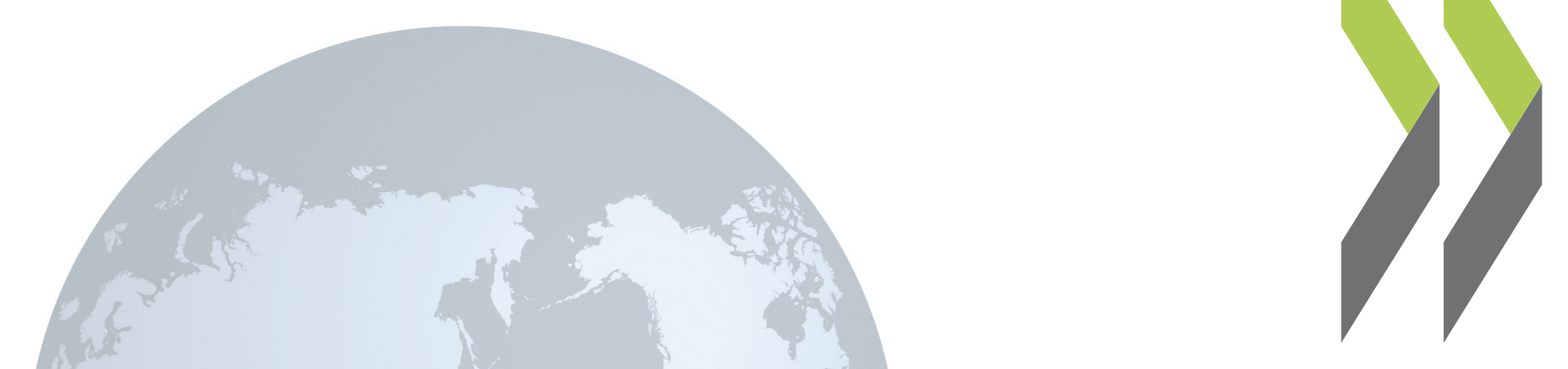

SIGMA Papers No. 40

Central Public Procurement Structures and Capacity in Member States of the European Union

\title{
OECD
}


Organisation de Coopération et de Développement Economiques

Organisation for Economic Co-operation and Development

30-Mar-2007

PUBLIC GOVERNANCE AND TERRITORIAL DEVELOPMENT DIRECTORATE

English - Or. English

SIGMA - A JOINT INITIATIVE OF THE OECD AND THE EUROPEAN UNION, PRINCIPALLY FINANCED BY THE EU

\section{CENTRAL PUBLIC PROCUREMENT STRUCTURES AND CAPACITY IN MEMBER STATES OF THE EUROPEAN UNION}

SIGMA PAPER No. 40

This study provides an analysis of the functions, structures and capacity of the central public procurement bodies of Member States.

Twenty-two separate overviews of public procurement systems in the 22 participating Member States were produced on the basis of national responses to a detailed questionnaire. An in-depth review of these country system overviews provided the comparative analysis portion of this study, which discusses from different angles the various models in place in Member States.

For further information please contact Mr. Peder Blomberg, Sigma; Tel: (33 1) 45248551 - Email: peder.blomberg@oecd.org 

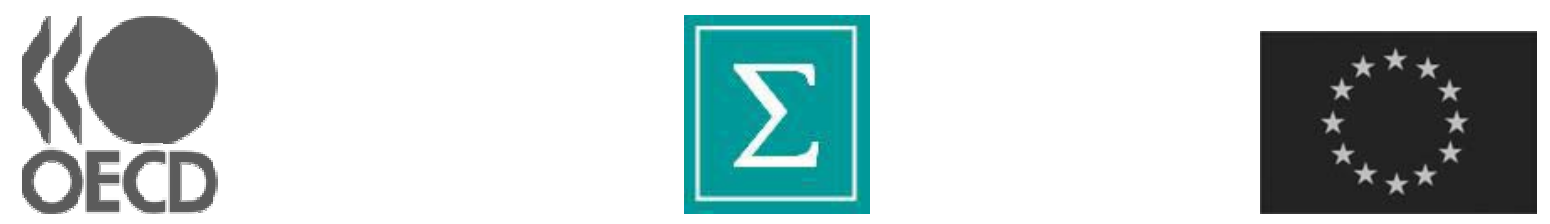

SIGMA

Support for Improvement in Governance and Management A joint initiative of the OECD and the European Union, principally financed by the EU

\title{
CENTRAL PUBLIC PROCUREMENT STRUCTURES AND CAPACITY IN MEMBER STATES OF THE EUROPEAN UNION
}

\author{
Sigma PAPER No. 40
}

This document has been produced with the financial assistance of the European Union. The views expressed herein can in no way be taken to reflect the official opinion of the European Union, and do not necessarily reflect the views of the OECD and its member countries or of the beneficiary countries participating in the Sigma Programme. 


\section{THE SIGMA PROGRAMME}

The Sigma Programme - Support for Improvement in Governance and Management — is a joint initiative of the Organisation for Economic Co-operation and Development (OECD) and the European Union, principally financed by the EU.

Working in partnership with beneficiary countries, Sigma supports good governance by:

- $\quad$ Assessing reform progress and identifying priorities against baselines that reflect good European practice and existing EU legislation (the acquis communautaire)

- $\quad$ Assisting decision-makers and administrations in setting up organisations and procedures to meet European standards and good practice

- $\quad$ Facilitating donor assistance from within and outside Europe by helping to design projects, ensuring preconditions and supporting implementation.

In 2007 Sigma is working with the following partner countries:

- $\quad$ New EU Member States - Bulgaria and Romania

- $\quad$ EU candidate countries - Croatia, the former Yugoslav Republic of Macedonia and Turkey

- Western Balkan countries - Albania, Bosnia and Herzegovina (State, Federation of $\mathrm{BIH}$, and Republika Srpska), Montenegro, Serbia and Kosovo (governed since June 1999 by the UN Interim Administration Mission in Kosovo - UNMIK)

- $\quad$ Ukraine (activities financed by Sweden and the UK).

The Sigma Programme supports reform efforts of partner countries in the following areas:

- $\quad$ Legal and administrative frameworks, civil service and justice; public integrity systems

- $\quad$ Public internal financial control, external audit, anti-fraud, and management of EU funds

- $\quad$ Public expenditure management, budget and treasury systems

- $\quad$ Public procurement

- Policy-making and co-ordination

- Better regulation.

For further information on Sigma, consult our website:

http://www.sigmaweb.org

\section{Copyright OECD, 2007}

Application for permission to reproduce or translate all or part of this material should be made to: Head of Publications Service, OECD, 2 rue André Pascal, 75775 Paris Cedex 16, France. 


\section{FOREWORD}

The Member States of the EU need organisational structures to carry out public procurement functions. These tasks range from the drafting of relevant legislation and development of public procurement policies to the training of procurement officers and publication of contract notices. The majority of EU Member States has central public procurement bodies within their governmental structures. Although differing in terms of responsibilities, functions and tasks, these bodies have several features in common. In comparison with the fairly uniform picture found in the new Member States, the 15 "old" Member States show a more diversified picture. The perceived differences in how central procurement functions have been organised in Member States give rise to a number of basic issues, such as:

- $\quad$ the main reasons for the differences between Member States in the establishment of organisational models and functions;

- $\quad$ the feasibility of identifying advantages and disadvantages of certain models in organising some of the key responsibilities linked to central procurement functions, taking into consideration the specific circumstances applicable to the new Member States and candidate countries.

For the new Member States, the emergence of central public procurement bodies is seen to have contributed strongly to the successful recent development and comparably favourable position of the public procurement systems in these countries. All of the key stakeholders of a public procurement system - including parliament, government, contracting entities, the private sector and citizens - rely extensively on how well public procurement bodies support the development of a sound and efficient national procurement system. The availability of sufficient administrative capacity, whatever organisational model or system is in place, will remain equally important for all current and future Member States. This is particularly the case in view of the foreseen changes that will take place within the next decade in terms of the legislative and regulatory framework, technological development, public sector development, capacity-strengthening and performance measurement, integrity enhancement, and international co-ordination and co-operation.

This study provides an analysis of the functions, structure, status within the government, and capacity of the central public procurement bodies of Member States. It does not attempt to evaluate their respective advantages/disadvantages or to recommend particular institutional arrangements. Twenty-two separate overviews of public procurement systems in the 22 participating Member States were produced on the basis of national responses to a detailed questionnaire. An in-depth review of these country system overviews provided the comparative analysis portion of this study, which discusses the various models in place in Member States, in particular the background and rationale for the use of a particular institutional model.

It is Sigma's view that a better understanding and knowledge of the organisation and capacity of central public procurement structures and capacity in EU Member States will serve as an inspiration and assist current and future EU candidate countries and other Sigma partner countries in their efforts to set up or reform their public procurement systems. 


\section{Methodology}

This study was carried out by the Sigma Project Team and reviewed by a Peer Team. The necessary data was collected by means of a detailed questionnaire, which was sent in 2006 to Contact Points in the $25 \mathrm{EU}$ Member States at the time as well as to Bulgaria and Romania (EU accession in January 2007). The study reflects the situation in Member States as at August 2006. All Member States have been given the opportunity to comment on the individual country reports (see Appendix).

Members of the Sigma Project Team were Mr. Martin Trybus, Mr. Peder Blomberg and Mr. Piotr-Nils Gorecki. A Peer Team was established with the purpose of providing comments on the methodology, the questionnaire, and the draft and final reports. This team was composed of Mr. Tomi Hytonen (Finland), Mrs. Gabriele Herlemann (Germany), Mr. Marian Lemke (Poland), and Mrs. Lourdes Camacho (Portugal).

A Network of Contact Points within Member States' public administrations was created, with the task of providing the Sigma Project Team with the requested documentation and information on how central procurement organisation was structured and perceived. The majority of Contact Points was selected from among members of the European Public Procurement Network (PPN), which is an international co-operation network of public procurement expert officials, involving all EU Member States, EEA Members, Switzerland, EU candidate countries and other European countries.

The Sigma Project Team prepared a detailed questionnaire, which was sent to the network of Contact Points for completion. Insofar as possible, the Sigma Project Team and the Peer Team analysed the material as a basis for the preparation of the individual country reports and the comparative analysis. A total of 22 questionnaires were returned to the Sigma Project Team between March and August 2006, namely by Austria, Bulgaria, Cyprus, the Czech Republic, Estonia, Finland, France, Germany, Hungary, Ireland, Italy, Latvia, Lithuania, Luxembourg, Malta, Poland, Portugal, Romania, the Slovak Republic, Slovenia, Sweden and the United Kingdom.

A number of remarks need to be made with regard to the limits of this methodological approach. First, not all EU Member States returned the questionnaire. The study therefore does not constitute a complete overview of central public procurement structures in all current Member States. However, 22 out of 27 possible returns represent a positive response that should be sufficient to provide the basis for a meaningful overview. Second, the Contact Points did not provide answers to all items on the relatively extensive questionnaire, at times because the required information was simply not available to them. Thus the coverage of national systems in the report is uneven, since some Contact Points provided very extensive information, whereas the responses of others remained limited. Third, there is a certain potential for misunderstandings between the Project Team and the Contact Points. The entire study, including the questionnaires, was conducted in English. This problem was addressed at least in part by the fact that all finished country reports were sent back to the Contact Points for comments. The data submitted by Member States nevertheless provides an objective overview of public procurement systems in place.

The study does not make any specific reference to the nature of the contracts falling under the responsibility of central public procurement bodies. In some Member States these organisational arrangements may have had an impact on the conclusions made in the comparative overview section of the study. This is in particular relevant to Member States where the regulatory responsibilities for concessions are not exercised by the same bodies that are in charge of the regulation and monitoring of public procurement contracts but separately by a different 
organisation. The study thus lacks systematic information on how Member States organise regulatory and support structures, with specific reference to the type of contracts.

The basic assumption guiding the study is that Member States organisationally do not make any distinction on the basis of the size of the public contract; i.e. differentiation based on whether contracts fall above or below the EC thresholds. However, Member States generally regulate procurement outside the scope of the EC Directives differently; in some Member States these contracts may even be unregulated, which in principle could also have certain institutional effects, but it has not been possible to consider in this study the implications of such an eventuality. 


\section{TABLE OF CONTENTS}



FOREWORD

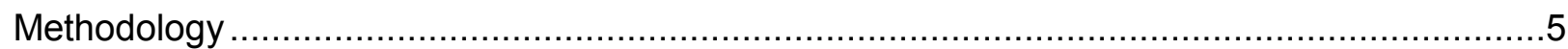



PART I. DEFINING A CENTRAL PUBLIC PROCUREMENT STRUCTURE ......................11



1. Identification of Key Central Public Procurement Functions ....................................12



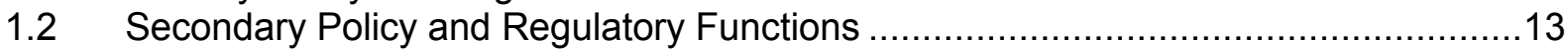

1.3 International Co-ordination Functions .............................................................

$1.4 \quad$ Monitoring and Control Functions.................................................................. 14

1.5 Advisory and Operations' Support Functions................................................. 14

$1.6 \quad$ Publication and Information Functions............................................................... 15

1.7 Professionalisation and Capacity-Strengthening Functions .................................16

1.8 Development and Procurement Co-ordination Functions …................................16

1.9 Related but Non-applicable Functions ...........................................................

2. Classification of Core Functions and Supplementary Functions ..............................18

3. Organisational Location and Status within the Public Administration ...........................18

4. Model for Classification of Central Public Procurement Structures .............................19

PART II. COMPARATIVE ANALYSIS OF CENTRAL PUBLIC PROCUREMENT

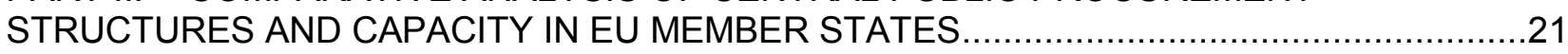

5. Central Public Procurement Structures and Institutional Models ................................21



5.2 Main Organisational Design of Core and Supplementary Procurement Functions .....21

5.3 Member States with a Centralised or Semi-centralised Public Procurement Structure 24

5.4 Member States with a Decentralised Procurement Structure .................................25

5.5 Examples of Decentralisation in the Public Procurement Structure ........................27

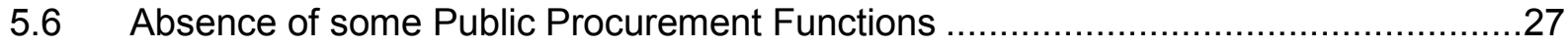

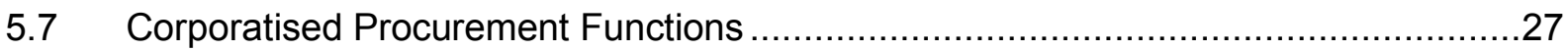

6. Institutional Models and Internal Organisational Design of the Main Public Procurement

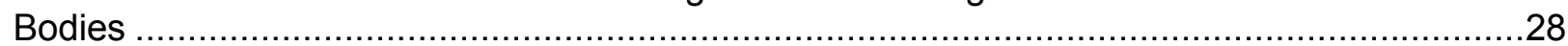

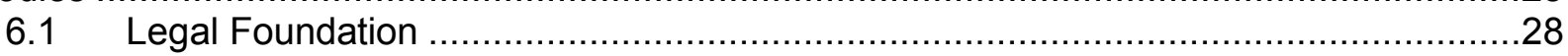

6.2 Overview of Organisational Design and Decision-making Structures .....................29

7. Administrative Capacity of Central Public Procurement Structures...............................35

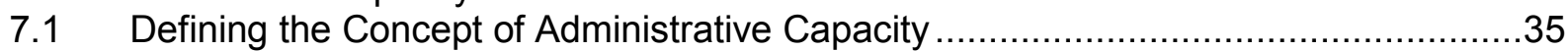

7.2 Administrative Capacity of Central Procurement Bodies.........................................

8. A Changing Public Procurement Environment......................................................... 
GOVISIGMA(2007)4



ANNEX COMPARATIVE OVERVIEW OF PUBLIC PROCUREMENT STRUCTURES IN EU

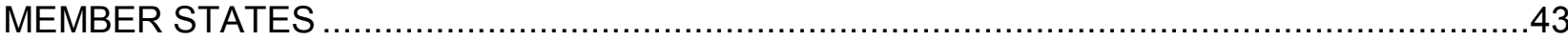

APPENDIX INDIVIDUAL COUNTRY REPORTS OF EU MEMBER STATES .....................49 
GOV/SIGMA(2007)4

\section{EXECUTIVE SUMMARY}

The possible functions to be performed by central public procurement institutions can be separated into tasks relating to policy and primary legislation, international co-ordination, administrative and monitoring tasks, development and business co-ordination, publication and information, advisory and operations' support, training and knowledge development.

For the purposes of this study, tasks relating to policy and primary legislation, international co-ordination, and administrative and monitoring tasks are classified as "core functions", and all remaining tasks are referred to as "supplementary functions". Core functions are defined as those functions that are all regulated by national law, often in direct response to obligations connected to membership in the European Union. These functions therefore need to be dealt with at central government level, which also is found to be the case. Consequently, all other functions, although extremely important for the functionality of a public procurement system, can be classified as supplementary functions, since they are not assigned as an obligation under law by all Member States across the European Union.

The remedies and central purchasing functions are not covered by this study, but since these functions are sometimes carried out within the same organisational structure as the core and supplementary functions, they have been briefly addressed in the study.

The 22 EU Member States participating in this study can be separated into three broad groups according to their public procurement structures. Eleven Member States have been deemed to have a centralised procurement structure, with a high concentration of procurement functions allocated to a few central institutions; nine Member States have been found to possess a semi-centralised procurement structure, with a mixed concentration of procurement functions allocated to a number of institutions; and finally, two Member States fall within the category of a decentralised procurement structure, with a dispersed concentration of procurement functions allocated to a range of bodies within the public administration.

All Member States have organised core functions in a centralised manner, while supplementary functions may be carried out by a broad spectrum of bodies, including the private sector, at both central and decentralised levels of the public administration.

In some Member States, the legislative and policy functions are exercised by the ministerial structure, while other important procurement functions are assigned to a special procurement body, which may be part of the government or subordinated to the legislature.

In Member States having a public procurement structure with one dominant procurement institution, the legislative and policy functions are normally exercised by the same institution. Hence legislative functions are only carried out in dominant institutions that are part of the government. Government advice, procurement policy development, international co-operation and certain monitoring functions - in other words the "core functions" indicated above - are also normally exercised by the dominant institution. The tasks related to training and research, development and business administration, publication and information, and administrative and monitoring tasks are carried out outside the dominant institution.

In Member States with semi-centralised or decentralised procurement structures, relevant tasks are divided between various institutions and organisations. While some institutions, most notably the respective ministries of finance or treasuries, are always in charge of the regulatory functions, there is not always a focal point of organisation with a strong emphasis on a particular institution or organisation, and in particular this is applicable to Member States with a more decentralised 
structure. This category is the opposite of the centralised procurement structure, which is characterised by a high concentration of functions being assigned to a few institutions.

The study concludes that administrative capacity is not only linked to the amount of staff and financial resources available within central procurement institutions, but needs to be more broadly defined. The total accumulated capacity of Member States to support public procurement operations may be strong if all actors in the society are included, such as associations of local and regional authorities, large contracting entities and utilities, training institutions, and law firms, and it is thus not limited to the capacity of central institutions. However, the study reveals some interesting information on the extent of resources allocated at the central level. At the same time, it should be kept in mind that the size of central procurement institutions in terms of the number of staff is dependent on a number of factors, such as the size of the economy and the number of contracting entities and procurement contracts, and does not necessarily reflect government priorities. The number of staff in central procurement institutions varies among Member States. Moreover, since many of the relevant institutions deal with several issues in addition to the public procurement functions outlined above, it is not always clear how many people are actually working on core and supplementary central public procurement functions.

Public procurement in most Member States appears to be financed from the general governmental or ministerial budget, and in all Member States the greater part of procurement costs is covered by such a budget. Hungary and Poland receive additional income from fees and deposits that have to be paid for review proceedings. However, such an arrangement means that this function of review must be carried out by the same institution that exercises central public procurement functions, as defined in this study.

Whatever organisational model is chosen, it appears that public procurement is usually the responsibility of the Ministry of Finance, the Ministry of Economy, or the Ministry of Works. The legal foundation is frequently the public procurement law or administrative law. Some Member States have established public procurement offices or agencies, which are given a more independent status under parliament or directly under the government, while others act as departments within ministerial structures. Some functions of an operational nature are carried out by public firms.

The evolution of key procurement functions is briefly discussed in the light of a changing public procurement environment, which is gradually growing in complexity as an effect of the introduction of new procurement instruments and mechanisms, technological developments, and stronger emphasis on efficiency in the delivery of public services. Any procurement structure will need to consider how to best achieve an increased professionalisation of the procurement function and meet the subsequent need to develop, in particular, the procurement support structure. It is therefore vital to find the appropriate global organisational model that strikes an effective and natural balance between the specificities of the functions involved and the requirements of these functions in terms of independence and interaction, while at the same time avoiding conflicts of interest. 
GOV/SIGMA(2007)4

\section{PART I. DEFINING A CENTRAL PUBLIC PROCUREMENT STRUCTURE}

\section{Introduction}

All EU Member States organise important public procurement functions within their public administrations, but they differ in terms of how they organise these functions, the legal foundation for the organisational set-ups, the scope of these functions and where they are located within the administrative structure, the actual distribution of functions and responsibilities among the various central procurement bodies and how they interrelate, and finally the capacity and resources assigned to the various bodies.

Sigma has over the years actively supported public procurement reform within the group of Member States that recently entered the EU (2004 and 2007). A vast majority of these countries has a common historical background as former communist countries, where state planning and acquisition systems were applied without any use of competitive procurement procedures based on market economy principles. Initially, one key challenge in the procurement reform process, alongside the reform of the legal component, was the issue of how best to organise the central organisational structure for the co-ordination, implementation and monitoring of public procurement in a country. The establishment of a strong focal point for public procurement at high central level, which is given a fairly wide scope of functions and responsibilities, was - and still is - seen as a vital measure for countries in the process of building up their public procurement systems. This could basically be seen as a centrally-driven approach, where "the centre" is the initiator and is placed in the driver's seat of procurement reform work. As will be discussed later in the comparative overview, the other group of Member States with a longer history in the European Union demonstrates a far more diversified picture in terms of how central procurement functions are arranged, in comparison to the fairly uniform picture shown by the group of recently acceded Member States. The variation of institutional systems in the area of public procurement within the "older" group of Member States can first of all be explained by differences in their legal, political and administrative traditions, but also by another relevant explanatory factor. Public procurement - as a commercial operation within the public administration - has developed gradually for more than a century, and specific national systems have been formed as a result of continuous developments in society, such as the emergence of the welfare state, a progressive redefinition of the role of the government, significant changes in market systems, closer international and regional co-operation, evolving political priorities (e.g. environment), and finally - but not least of all - in the areas of communications and information technology. The need to establish central procurement structures in these countries could be seen to have grown more as a result of a peripherally-driven approach, where the pressure for strengthening certain, but not all, functions at the central level could be regarded as an effect of long-term changes in the external environment, requiring a successive adaptation of the functions and role of the central public administration. Furthermore, the demand for central procurement functions has often been triggered by a stated interest at the operational level purchasers and economic operators - in government initiatives for the creation of appropriate support systems that reflect the growing complexity in various areas of the public procurement system. This demand has also resulted from external commitments (such as membership in the EU and the WTO), together with the introduction of new complex regulatory frameworks in the area of public procurement and the need to establish points of contacts for external communication.

The Sigma study has identified a wide range of tasks performed by such bodies, which may include the preparation of national public procurement legislation, advice to contracting entities and economic operators on the application of legislation, the provision of public procurement training, publication of contract notices, or dealing with the European Commission and other 
international institutions. In some countries a majority of these tasks is combined in one central institution; in other countries they are shared between several central institutions, whereas some countries may lack central institutions for the performance of some of these tasks. There are hardly any explicit legal requirements on central procurement organisation and capacity in the EC Treaty, the EC public procurement directives, or any other source of secondary Community legislation. The only exception is that the EC Remedies Directives 89/665/EC and 92/13/EC require a last-instance, independent review of public procurement decisions. However, new EU Member States and EU candidate countries are or have been confronted with this issue as one of the key criteria under the public procurement chapter for accession to the EU. It is not sufficient for a candidate country to simply comply with the acquis; it is equally important that acceding countries demonstrate that they have a satisfactory degree of administrative capacity at central government level to implement national legislation transposing the EC Directives, to monitor public procurement operations effectively, and to meet all other obligations under the EC Directives, the EC Treaty, and EU financing after the date of accession. These obligations imply establishing appropriate institutions and mechanisms, including those dealing with remedies, and ensuring that these institutions are adequately staffed and have the capacity to exercise all of their functions efficiently, which may cover a wide range of both core and supplementary procurement functions.

\section{Identification of Key Central Public Procurement Functions}

Based on the questionnaires received and Sigma's own experience, and with a view to improving the overview of how central public procurement functions are organised in Member States, this report provides a basic structure of the main procurement functions identified, including a classification of these functions in organisational terms. Certain overlaps between the various functions within such a broad classification are nevertheless unavoidable. The classification of central functions, as provided below, has been made for the purposes of this study only, and should not be seen as model for organising public procurement structures. In this context, reference can be made to the discussions in the margin of the Advisory Committee and the agreement between the group of new Member States (ten plus) and the Commission Services on the list of key procurement functions.

As further described below, the main functions to be performed by central public procurement institutions can be categorised as follows:

1. Primary policy and legislative functions

2. Secondary policy and regulatory functions

3. International co-ordination functions

4. Monitoring and control functions

5. Advisory and operations' support functions

6. Publication and information functions

7. Professionalisation and capacity-strengthening functions

8. Development and procurement co-ordination functions

In some Member States the central purchasing functions and the enforcement and remedies functions are part of the central public procurement structure, but in view of their specific nature these functions are not covered by this study, but only briefly addressed in the discussions that follow. As will be discussed later in the report, there is a considerable diversity of institutional set-ups identified in Member States, but the uniformity of functions performed across public procurement structures is striking. 


\subsection{Primary Policy and Legislative Functions}

All Member States have designated bodies at the government level with the task of developing fundamental procurement policies aimed at setting the overall governing legal framework for public procurement operations. The most important function in this context is to prepare and draft primary public procurement legislation, which includes national legislation implementing the EC Public Procurement Directives as well as the regulatory or policy framework that will apply in areas outside the scope of the EC Directives. All Member States have transposed the EC Directives (but still not all Member States have transposed the new Directives) into primary legislation, but not all of them have regulated in the primary law the areas not covered by the directives. Apparently, the drafting legislative function is frequently exercised by the Ministry of Finance/Treasury, Ministry of Economy, and Ministry of Justice, either organised separately or as a component of a central public procurement body. Within this function the following tasks are commonly assigned:

- $\quad$ To lead the working group in the drafting process and to organise the consultation process with the main stakeholders in the procurement system;

- $\quad$ To take part in other legislative activity of relevance to public procurement;

- $\quad$ To determine the thresholds in national currencies - unless set by the Commission for non-EU countries - for the application of the public procurement law in accordance with EC Directives and with those of national concern only.

\subsection{Secondary Policy and Regulatory Functions}

Secondary policy and regulatory functions relate to regulations that are adopted formally by the government in order to give effect to primary law in specific areas or to provide implementing tools in support of the application of primary law. There are clear differences between Member States with respect to the need for and extent of secondary legislation. Some Member States operate without any secondary legislation at all or to a very limited extent, and may instead rely, for example, on the recitals (interpretative notes behind the various provisions) for the preparation of primary law in parliaments, on interpretative communications by designated bodies, or on court precedence. Other Member States require by law the issuance, in a varying degree, of a set of secondary legislation, in some cases even as a condition for the effectiveness of primary law. Other Member States may further complement primary and secondary legislation with the provision of tertiary legislation (e.g. operational guidelines) adopted by the designated central procurement bodies. The set of supplementary regulations may include the following types of documentation:

- Implementing regulations, covering technical aspects of the procurement process, areas not covered by primary law or areas where clarifying application instructions are needed;

- $\quad$ Operational guidelines;

- $\quad$ Standard formats for contract notices in cases where the EU standard forms are mandatory;

- $\quad$ Model tender documents for goods, services and works, including instructions to tenderers, tender forms and technical specifications;

- Model general conditions of contracts for goods, services, works and concessions, including contract forms. 


\subsection{International Co-ordination Functions}

The co-ordination of international and intra-European public procurement activities is an important function of a member state, which normally would cover any or all of the following tasks:

- To be responsible for the national contribution to international regulatory activities, amongst others, in the area, such as the Government Procurement Agreement of the World Trade Organisation or the Model Law of the United Nations Commission for International Trade Law;

- $\quad$ To be responsible for the national contribution to the EU advisory committee and its working groups dealing with public procurement;

- $\quad$ To act as a national contact point for the European Commission for questions and enforcement proceedings on the basis of article 226 of the EC Treaty;

- $\quad$ To participate, either as a representative of an institution or as an individual expert, in international networks, such as the European Public Procurement Network (PPN);

- $\quad$ Co-operation with corresponding institutions in other countries.

\section{$1.4 \quad$ Monitoring and Control Functions}

As the areas of monitoring and control of public procurement in Member States are regulated by national law and by obligations under the EC Directives, these functions play a central role in all national public procurement systems. Control in this context does not cover the responsibilities of internal and external audit institutions or of complaints review bodies, but refers only to tasks exercised by central public procurement institutions. Such functions have to been found to include the following tasks:

- $\quad$ Preparation of an annual report to the government on the functioning of the national public procurement system;

- Collection of statistical and other information on, inter alia, public procurement planning, market penetration, awarded contracts, and performance and efficiency of the public procurement system (including collection of data on the public procurement market, as stipulated by the EC Directives);

- $\quad$ Exercise of an authorising function by granting prior approval to contracting entities on certain decisions in the procurement process, such as the use of less competitive procedures or of accelerated procedures;

- Management of an official list of certified economic operators and/or certified procurement officers;

- $\quad$ Although not recommended by the European Union, management by some Member States of official blacklists of economic operators who violated public procurement rules, did not fulfil their contracts, or misrepresented information.

\subsection{Advisory and Operations' Support Functions}

These important functions are in place in all Member States to support contracting entities as well as economic operators in their respective tasks so as to enable them to act efficiently and in compliance with national legislation, the fundamental principles of the EC Treaty, and good practices. Specifically, the legal advisory functions are normally the responsibility of the centrally 
placed public procurement bodies, but in addition, some of these functions are often shared and exercised by a great number of players within the public procurement community, such as associations for regional and local administrations, large contracting entities and utilities, the private sector (consultants and law firms), chambers of commerce, and associations of small and medium-sized enterprises (SMEs). In particular, the professional support functions appear to be managed by a number of actors within the procurement structure and community. Commonly associated with the advisory and operations support functions are the following:

- $\quad$ Organisation of a help-desk function to provide legal and professional support to purchasers and economic operators on a daily basis;

- $\quad$ Development of guidance systems and operational tools - Internet and paper-based for managing all phases of the procurement process, e.g. methodologies for tender evaluation;

- Issuance of publications, commentaries and interpretative communications on various subjects.

In some Member States some of the tasks and documentation used are formally adopted by secondary legislation (see 1.2 above).

\subsection{Publication and Information Functions}

In a number of Member States various publication functions may be assigned to a central procurement body. It might be in charge of the administration of the national public procurement bulletin, which is progressively being replaced in Member States by a central website for the publication of contract notices above EC thresholds and other national thresholds. This task may also include a quality control of notices before publication or before submission to the publication office in Luxembourg (TED), which in some instances may also include notices regarding contracts below the EC thresholds. Regarding contracts above the EC thresholds, the central body may be assigned the responsibility of conducting the communication of notices of contracting entities and utilities to the Official Journal of the European Communities, which would include the task of rejecting draft notices that did not fulfil the requirements of the EC Public Procurement Directives or the EC Treaty. The publication and distribution of information on public procurement legislation and policy, including sources of additional information, materials and advice, is another related task. This information can include paper versions as well as Internet resources or resources of any other media. In more detail, tasks linked to this function may include:

- Issuance of contract notice models and of instructions on how to use them;

- $\quad$ Operation of Internet-based publication systems of tender and award notices, including the processing of notices, quality and legality controls of received notices, publication of notices, and submission of notices to TED;

- $\quad$ Maintenance of public procurement registries or other procurement databases (which are also used as part of the monitoring function, see 1.4 above);

- Maintenance of lists of contracting entities;

- $\quad$ Operation of an Internet-based information and guidance system to support the procurement community, including guidance documentation, model tender and contract documentation, interpretative and commentary communications (which are also part of the advisory functions, see 1.5 above). 


\subsection{Professionalisation and Capacity-Strengthening Functions}

Professionalisation of procurement tasks and capacity-strengthening of procurement operations are seen as crucial functions in increasing the efficiency of any national public procurement system. These functions can be assigned to central procurement bodies, and may include the initiation and co-ordination of national training programmes for the public sector and the utilities sector; facilitation of independent teaching and research in universities, training colleges, and through private companies; the organisation of a research programme on public procurement law, economics and policy; and participation in national and international academic and other events on public procurement law, economics and policy. Training is a key activity within this function, but the central body acts more in the capacity of initiator (which includes responsibility for defining training policy), facilitator and co-ordinator of procurement training for public purchasers and economic operators rather than acting as the implementer of training programmes. The practical involvement of central procurement bodies is usually limited to the organisation of conferences and seminars of an informative nature, with presentations of legislation and other connected areas, which are an important responsibility of these bodies. However, it may involve the preparation of training programmes and material, but the more comprehensive, specialised and long-term capacity-strengthening activities are usually conducted by universities, research institutions and, last but not least, the private sector. In some Member States, central bodies are responsible for various accreditation schemes of public procurement officials or procurement consultants. However, professionalisation and capacity-strengthening are not limited to training and research; this function accommodates a much wider approach and challenge, namely:

- To broaden the concept of public procurement beyond the tendering phase and compliance with the regulatory framework to cover all phases of the procurement cycle;

- $\quad$ To put the procurement function on the political map, so that it is recognised as a key strategic factor in the provision of efficient services to the public at lowest possible cost;

- $\quad$ To ensure that procurement is mainstreamed into the centre of the budget and public expenditure process;

- To attract adequate professional procurement expertise and increase the status of the procurement profession;

- $\quad$ To determine how best to organise and manage procurement operations at the contracting level;

- $\quad$ To optimally design decision-making structures and find the right balance between discretionary power and control.

\subsection{Development and Procurement Co-ordination Functions}

Finally, the study reveals a group of functions in place within public procurement structures which either do not fall naturally within any of the other central functions listed above or deserve particular attention. Development and procurement co-ordination functions become important in all Member States as a result of the steady increase in the demand for central government initiatives and organisational and operational support in areas subject to rapid technological and significant legislative changes, such as the new EC Directives. In some Member States these functions have become the responsibility of the main central procurement bodies, while in others these functions and responsibilities are assigned to specialised bodies, with the exception of the purely legislative and monitoring functions, which rest with the central procurement regulatory 
bodies. Development and procurement co-ordination functions may include any of the following tasks:

- $\quad$ Facilitation and co-ordination of framework agreements in government sectors and municipalities;

- $\quad$ Co-ordination and support of concessions/PPP projects;

- $\quad$ Development of systems and methodologies for e-procurement;

- Introduction of systems for performance measurement of public procurement;

- $\quad$ Development of procurement techniques, such as performance-based technical specifications;

- $\quad$ Launching of initiatives for the elaboration of contract models to be used in the public sector.

\section{$1.9 \quad$ Related but Non-applicable Functions}

\subsubsection{Central Purchasing}

A central body may act as a central purchasing unit for other contracting authorities at local, regional and national levels and for utilities. The possibility to set up such central purchasing units is expressly recognised in the new Directives 2004/17/EC and 2004/18/EC. In some jurisdictions the central purchasing function was the organisational foundation for assuming all of the other functions. In other words, functions such as developing procurement policy and acting as a contact point for the Commission were later additions to the list of tasks of a unit that was primarily concerned with central purchasing. However, the central purchasing function is not considered a procurement function for the purposes of this study. Nevertheless, the location of this central purchasing function was also a subject of inquiry to determine whether it was exercised separately from the other central procurement functions.

\subsubsection{Review and Remedies}

Certain tasks in the context of the review, remedies and enforcement components of the public procurement system may be located within the central public procurement structure. A number of administrative enforcement functions may be assigned to a central procurement body, such as:

- Imposition of fines on contracting authorities who violated public procurement rules;

- $\quad$ Disciplinary measures against individual contracting officers.

However, the most important functions relate to dispute settlement and complaints review, which may involve the following functions:

- $\quad$ Non-judicial resolution of disputes between contracting entities and contractors;

- Initiation of proceedings for judicial review in courts of law of violations of public procurement law or for prosecution of cases of corruption and other criminal offences in public procurement;

- $\quad$ Preparation of the rules for arbitrators and administration of the list of arbitrators;

However, it needs to be pointed out that Directives 665/89/EEC and 92/13/EC require that last-instance judicial review - in other words, judicial review leading to a decision or judgment against which there is no further appeal at the national level - be located in an independent 
review body, chaired by a lawyer. This requirement imposes limitations on the location of the last-instance judicial review body in the same organisational structure as are other central procurement functions.

Hence last instance judicial review is not considered a procurement function for the purpose of this study. However, the location of this last-instance judicial review function was also a subject of inquiry to determine whether it was exercised separately from the other central procurement functions.

In conclusion, central purchasing and enforcement and remedies are not subject to the study, but they need to be mentioned as in some Member States some aspects of these functions may be important components within the framework of the central public procurement structure. These functions are essential elements of a public procurement system, but they are normally and positively exercised separately from the central policy-making and advisory functions of the central procurement structure. The combination of these functions within the same structure may give rise to situations of conflict of interest and may even run the risk of incompatibility with EU requirements.

\section{Classification of Core Functions and Supplementary Functions}

For the purpose of this study, the functions identified and listed above may be classified as either core functions or supplementary functions, but this categorisation is not made on the basis of their importance but rather with reference to the nature of the tasks involved. Core functions are defined as those functions that are all regulated by national law, often in direct response to obligations connected to membership in the European Union. These functions therefore need to be dealt with at central government level, which also is found to be the case. The core functions are the following:
a) Primary policy and legislative functions
b) Secondary policy and regulatory functions
c) International co-ordination functions
d) Monitoring and control functions

Consequently, all other functions, although extremely important for the functionality of a public procurement system, can be classified as supplementary functions, since they are not assigned as an obligation under law for all Member States across the European Union. Nevertheless, these functions may be handled by centrally located procurement bodies within a public procurement structure, and this is definitely the case with respect to the regulatory and monitoring aspects of these functions. However, these functions are just as often shared or provided by many different bodies within the public procurement structure or in the wider public administration, as well as by the private sector. To the supplementary functions belong:
a) Advisory and operations' support functions
b) Publication and information functions
c) Professionalisation and capacity-strengthening functions
d) Development and procurement co-ordination functions

\section{Organisational Location and Status within the Public Administration}

An important area of interest for the purposes of this study is the administrative structure and constitutional status of the central procurement body. Questions in this context concern the 
location of the central procurement body or bodies in the institutional structure of the government, its legal foundation, as well as its status, main organisational set-up and functions.

As far as the location of the central procurement body or bodies is concerned, the study reveals that several organisational solutions are available. Central public procurement functions are exercised by central bodies that may be organised with a variety of reporting lines. Commonly these central bodies are organised within or subordinated to:

- $\quad$ Ministry of Finance or Treasury;

- $\quad$ Ministry of Works;

- $\quad$ Ministry of Regional Development;

- Office of the Prime Minister/ Chancellor/ President as a subordinate body;

- $\quad$ Council of Ministers;

- $\quad$ Parliament;

- Competition Authority or another public body.

There may be a multitude of units covering one or more public procurement functions and organised in a combination of institutional environments. Frequently, the policy and primary legislative functions are located in a ministry such as the Ministry of Finance or the Ministry of Justice, while at the same time advisory and publication functions are preferably found in central bodies with a different location and reporting line.

The status of the procurement body is another important area to address, since the status decides the role and potential influence that such bodies may exercise within the public procurement system. The status refers to the following elements:

- $\quad$ Position or location of the procurement body within the public administration (see above);

- $\quad$ Decision-making power, mandate and functions designated to the body and legal foundation for its authority (e.g. public procurement law);

- Independence of the management, as expressed by the conditions and procedures for appointment and dismissal of the management (e.g. chairman, director, head of unit);

- $\quad$ Organisational design, composition and personnel resources granted to the body;

- $\quad$ Financial means and amount of resources for staff and operational costs (e.g. general budget, special funds, and own financing);

- Means of supervision over the activities of the procurement body;

\section{Model for Classification of Central Public Procurement Structures}

Based on the information provided in responses to the questionnaire, Member States' public procurement structures may be classified into different groups according to how and where the core and supplementary procurement functions are organised.

Firstly, it can be concluded that all Member States have organised the four core procurement functions at the central level within their public administrations.

Secondly, any differentiation between the various national models will rather be made based on the degree of concentration of procurement functions assigned to the main central bodies. If a significant majority of functions, and in particular the core functions, are assigned to a few central 
bodies, those Member States are found to have a centralised procurement structure. The other extreme characterises Member States with a dispersed concentration of functions, where certain functions are assigned to a large number of bodies within the public procurement structure. These Member States fall within the category of a decentralised procurement structure. Between these two extremes, we may find a mixed concentration of functions, which might be seen as a very common situation, in particular in the group of "old" Member States, and recognised as a semi- centralised procurement structure.

It needs to be underlined that this classification of Member States' organisational structures is not done with any scientific precision, but only with the objective of identifying certain patterns and facilitating the reader's overview and understanding of the report. Indeed, this classification is debatable. 


\section{PART II. COMPARATIVE ANALYSIS OF CENTRAL PUBLIC PROCUREMENT STRUCTURES AND CAPACITY IN EU MEMBER STATES}

\section{Central Public Procurement Structures and Institutional Models}

With reference to the methodology section above, please note that the study does not make any specific reference to the nature of the contracts falling under the responsibility of central public procurement bodies, which may have had an impact on the conclusions made in the present section. This is in particular relevant to Member States where the regulatory responsibilities for concessions are, from an organisational point of view, handled separately from those bodies in charge of the regulation and monitoring of public procurement contracts.

\subsection{Classification Model Used}

Following the classification models discussed above, it appears that the 22 Member States participating in this study can be grouped into three categories according to how they have organised their central public procurement structures:

1. Member States with a centralised procurement structure are characterised by a high concentration of procurement functions being allocated to a few centrally placed institutions (normally one or two institutions);

2. Member States with a semi-centralised procurement structure are characterised by a mixed concentration of procurement functions being allocated to a limited range of institutions placed at various levels within the public administration (normally three or four institutions);

3. Member States with a decentralised procurement structure are characterised by a dispersed concentration of procurement functions being allocated to several institutions placed at various levels within the public administration, and often including private and public companies (usually more than five institutions involved).

\subsection{Main Organisational Design of Core and Supplementary Procurement Functions}

All Member States participating in this study, including those with a largely decentralised structure, have organised the core procurement functions (mainly policy and legislative functions, but also international co-ordination and monitoring) within their central public procurement structures, and the majority has a structure with a few institutions responsible for the main procurement functions. Actually, based on the classification model used, the majority of Member States participating in this study have, within the government administration, centrally placed institutions in charge of most or many of the procurement functions outlined above; these institutions thus have a dominant position within the procurement structure (see Annex).

However, these institutions differ with regard to the functions they have accumulated. Models range from a maximum of functions, such as in the Maltese Department of Contracts (DC) or the Polish Public Procurement Office (PPO), where only central purchasing and last-instance judicial review are excluded, to a minimum of functions, such as in Slovenia, where the Department for Public Procurement, Public Utilities and Concessions (DPPUC) only exercises the most important tasks. Thus further differentiations within the group of Member States with centralised procurement structures would be possible. However, all of these Member States have institutions that have accumulated the most important functions without any other institution being assigned a comparable number of essential functions. 


\subsubsection{Location of core functions within the public procurement structure}

\section{Policy and legislative functions}

Legislative and policy functions are frequently located in the respective central procurement body. This is the case in Bulgaria, Cyprus, Romania, the Slovak Republic, and the United Kingdom. Variations apply with regard to the preparation of legislation. In the United Kingdom the lawyers of the Treasury Solicitor's Department, who are based in the Office of Government Commerce (OGC), draft legislation on direction from the OGC.

However, depending on the status of the central public procurement body, the drafting of primary legislation and sometimes also secondary legislation is at times organised independently within the government structure. Normally the responsibility for these functions rests with the Ministry of Finance, Ministry of Economy or Ministry of Justice. This is the case, for example, in Estonia, where the Ministry of Finance, of which the PPO forms a part, is responsible for this task. Hence this function is carried out in close proximity and in connection to the Estonian PPO. In contrast, the Latvian PMB and the Lithuanian PPO are not directly involved in the preparation of legislation, although they are heavily involved in the consultation process, since these tasks are respectively the domain of the Ministry of Finance and Ministry of Economy.

Countries where the function of drafting policies and legislation is clearly separated from the main central procurement bodies are Estonia, Hungary, Italy, Latvia, Lithuania and Sweden.

\section{International co-ordination function}

This international co-ordination function includes, for example, responsibility for the national contribution to the EU advisory committee and its working groups dealing with public procurement and acting as national contact point for the European Commission for questions and enforcement proceedings on the basis of article 226 of the EC Treaty.

In most Member States this function is the responsibility of the central public procurement body or the body responsible for drafting legislation, but often this function is shared between two bodies, as is the case in Estonia, Hungary, Latvia, Lithuania and Sweden.

\section{Monitoring and control functions}

The areas of monitoring and control of public procurement in Member States are regulated by national law and by obligations under the EC Directives, and these functions thus play a central role in all national public procurement systems. With a few exceptions, Member States have organised these functions within the main central public procurement body. In addition to the obligations to provide annual statistics to the European Commission and the normal duty to prepare an annual report to the government on the functioning of the national public procurement system, a number of Member States operate systems of control on an ex ante basis in public procurement. The central public procurement body or a special designated unit may have the power to grant prior approvals to contracting entities related to certain decisions in the procurement process or to issue opinions during the process on compliance with the applicable regulatory framework. Some procurement bodies also have the task of managing an official blacklist - where such lists exist - of economic operators who violated public procurement rules, did not fulfil their contracts, misrepresented information, or offered a bribe.

Examples of Member States which have in place some form of control on an ex ante basis are: Cyprus, Estonia, France, Hungary, Latvia, Malta, Poland and Romania.

In conclusion, in Member States where the core functions are managed by more than one central procurement body, close co-operation and co-ordination between these bodies are needed. 
Normally for this group of Member States all of these bodies are represented in the Advisory Committee.

\subsubsection{Location of supplementary functions in the public procurement structure}

The group of supplementary functions is defined as activities in a public procurement structure without any explicit reference to, or obligation under, the EC Directives or the EC Treaty, but nevertheless of utmost importance for the functionality of a public procurement system. However, the countries that recently entered the EU have all recognised that "administrative capacity" to implement and monitor public procurement legislation effectively was an essential part of the accession process. This issue was consistently addressed in the regular Progress Reports issued annually by the European Commission, and it was an important element in the bilateral discussions and negotiations with the Commission Services during the years preceding accession.

\section{Advisory and operations' support functions}

The availability of help-desk functions within the central public procurement structures for the provision on a daily basis of legal as well as professional advice and support to purchasers, and frequently also to economic operators, is common among Member States, but the scope of these functions varies considerably between countries. Belonging to this category of tasks is the development of guidance systems and operational tools - Internet and paper-based - for managing all phases of the procurement process, e.g. methodologies for tender evaluation. The study concludes that legal advice functions are more commonly in place than typical professional support functions. Main explanations for this difference may be the specific composition of staff of the central bodies, with a majority of lawyers employed, and the fact that this area is normally considered to be the responsibility of other actors within the procurement community, including the private sector.

It is also evident that the group of new Member States has generally adopted a more centralised approach, with central procurement bodies offering a wider range of services than is the case in the other group of countries.

\section{Publication and information functions}

While most central procurement institutions provide information and guidance on public procurement by various means, including through their own websites, there are considerable differences with regard to the publication functions. For example, in Bulgaria, Estonia, Latvia, Poland and the Slovak Republic, the respective institutions have a publication function, mainly to ensure that contracts outside the application of the EC Directives are subject to central publication services. In other words, these institutions are in charge of a national contracts bulletin covering all contracts that are subject to publication obligations. Moreover, in Hungary and the Slovak Republic, for example, the procurement offices also check draft notices before they are forwarded to the Official Journal of the EU. In Ireland, Slovenia and the United Kingdom, the central procurement institutions have no so such function. Here the contracts bulletin or contracts section of the official gazette is organised outside the institution, and contracting authorities send their notices directly to the EU Official Journal.

\section{Professionalisation and capacity-strengthening functions}

Training, information and awareness campaigns are commonly exercised by the central procurement bodies, but their involvement is often limited, mostly covering legal and procedural aspects of new regulatory initiatives and legal acts, while in-depth training and knowledge development are carried out by other bodies, such as universities, private companies, or general national training colleges for the public sector. The procurement bodies act more as initiators, 
co-ordinators and facilitators for the creation of regular training programmes in the area of public procurement within the existing educational system, e.g. universities and colleges, rather than being practically involved in the delivery of such comprehensive training. Nevertheless, the central institutions of Member States provide input into the activities of these bodies, for example as speakers at their seminars and conferences.

\section{Development and procurement co-ordination functions}

With the introduction of the new EC Directives, this specific area of functions is gradually growing in importance in all Member States, but in particular in those countries where framework agreements and co-ordinated purchasing arrangements are completely new features. In some Member States these functions have become the responsibility of the main central procurement bodies, such as in the United Kingdom, while in other countries these functions and responsibilities are allocated in specialised bodies, such as in Sweden. Although it would in principle be possible to accommodate these functions within a central body responsible for policy and regulatory functions, Member States appears to be aware of the potential risks of conflicts of interest and even of becoming classified as a contracting entity. Therefore, the operational side of this function is normally organised in separate units, while the policy-related functions remain within the central body. In the United Kingdom a separate unit connected to the central procurement institution (OGC), called "OGC Buying Solutions", is in charge of procurement and of co-ordination of framework agreements for the government sector in certain product and service areas.

The operational side of e-procurement and IT issues in general are normally dealt with by specialised bodies within the public administration.

\subsection{Member States with a Centralised or Semi-centralised Public Procurement Structure ${ }^{1}$}

\subsubsection{Dual centralisation}

In two Member States all or most of the relevant tasks are divided between two main central procurement institutions. Moreover, these two institutions are independent from each other. This system could also be called "dual centralisation". The Czech Republic, with its Ministry of Regional Development and Office for the Protection of Competition, and Italy, with its Public Works Authority and CONSIP, form this group of Member States. Normally, the most notable difference between the two organisations is that one is a dependent part of the government, such as a ministry, whereas the other enjoys a certain level of independence. This dual centralisation allows the division of functions between a dependent and an independent institution.

In those Member States having a public procurement organisation with two dominant procurement institutions, the legislative and policy functions are located in the more dependent ministerial procurement institution rather than in the more independent procurement institution. In the Czech Republic these functions are located in the Ministry for Regional Development; in Italy primary legislation is drafted in parliament and in the Council of Ministers and secondary legislation in the Ministry of Infrastructure and Regional Institutions.

In the Czech Republic the Ministry for Regional Development is also in charge of some training, administration, development and business administration functions. Moreover, it is responsible 
for functions related to publication. The Office for the Protection of Competition is mainly responsible for complaints review and remedies; it also submits an annual report to parliament and to the government.

In Italy the Public Works Authority is in charge of some monitoring functions and dispute settlement; it reports annually to parliament and carries out some monitoring and administrative functions. CONSIP deals with training and research, monitors the public procurement system, covers certain publication, development and business administration functions, and acts as a central purchasing agency.

\subsubsection{Public procurement structures with a dominant procurement body}

In Member States having a public procurement structure with a key procurement institution, the relevant tasks may be divided between many different institutions and organisations, while one institution has a more significant position. As examples, Austria - with its Constitutional Service of the Federal Chancellery (BKA-VD), Germany - with its Federal Ministry of Economy and Technology (BMWi), Hungary - with its Public Procurement Council (PPC), and Luxembourg with its Ministry of Public Works - form this group.

In Austria the BKA-VD is in charge of legislative functions, international co-operation, and advice to the government. Moreover, it provides limited advice to contracting authorities. The other tasks are divided between the Federal Procurement Office (Bundesvergabeamt), Federal Ministry for Economy and Labour, Federal Ministry of Finance, the private Bundesbeschaffungs $\mathrm{GmbH}$, and the separately organised publication function, for example the "Lieferanzeiger".

In Germany the BMWi is also in charge of legislative functions, international co-operation, collection of statistical data, and some information tasks. The other functions are carried out by the Federal Ministry for Transport, Building, and Urban Affairs, Federal Government Co-ordination and Advisory Agency, Procurement Office of the Federal Ministry of the Interior, Federal Administration Office (Bundesverwaltungsamt), Federal Academy of Public Administration, the separately organised publication function, and Procurement Advice Offices.

In Hungary the Public Procurement Council deals with administration and monitoring functions, advises the government, participates in the preparation of legislation, and is in charge of international co-operation, training and publication. The other relevant functions are divided between the Ministry of Justice and Law Enforcement, Public Procurement Arbitration Board, Ministry of Foreign Affairs, Central Services Directorate, the private sector and universities, State Audit Office, and Government Control Office.

In Luxembourg the Ministry of Public Works prepares legislation and is also in charge of international co-operation; it co-operates with other ministries on many other tasks. The other functions are the responsibility of the Centre de Recherches, Audit Office, Directorate for Financial Control, Institut national de l'Administration publique, and private newspapers.

In Sweden, the NOU is responsible of policy development, monitoring, information, and the provision of advice to the government and tenderers. The other functions are divided between the Foreign Ministry, National Board for Trade Customer Services, Ministry of Finance, Central Statistics Agency, Competition Authority, private consultants and universities, and private publication companies, such as Allego and Opic.

\subsection{Member States with a Decentralised Procurement Structure}

In Member States with a decentralised procurement structure that is characterised by a dispersed concentration of procurement functions, the relevant tasks are divided between many 
different institutions. While some institutions, most notably the respective ministries of finance or treasuries, are always in charge of some of the core functions, there is no focal point of organisation and no emphasis on a particular institution or organisation. Finland and Portugal form this group. However, in the near future, Finland might remain the only country with such an organisation, since the Portuguese system may be subject to reform, moving towards a stronger centralisation of functions and a limited number of players.

Finland is the clearest example of a procurement structure with a decentralised system characterised by a clearly dispersed concentration of functions, where procurement functions are the responsibility of many institutions and where there is no dominant procurement institution. There are no plans to change this basic set-up in the near future. Important tasks are accumulated in the Ministry of Finance (policy development and standard documents) and in the Ministry of Trade and Industry (drafting legislation and some monitoring). However, the other functions are divided between the Ministry of Foreign Affairs, Governmental Board of Procurement, Public Procurement Advisory Unit, Association of Finish Municipal and Regional Authorities, State Audit Office, and the privately organised (but mainly publicly owned) HAUS Ltd., Efeko Ltd. and Hansel Ltd. Moreover, the country is vertically decentralised, since regions and municipalities have a strong role, partly through their national association. Again, there are no plans to change this basic structure.

In Portugal legislation is drafted by the government, and there is no specific body developing a national public procurement policy. The relevant functions are divided between various bodies, most notably the Direcção Geral dos Assuntos Comunitários, Direcção Geral do Património, Instituto de Mercados de Obras Públicas e Particulares Imobiliárias, Instituto Nacional de Administraçao and Direcç̧ão de Serviços do Aprovisionamento Público, which is part of the Direcção Geral do Património. Moreover, the country is vertically decentralised, since the Azores and Madeira have largely autonomous governments and municipalities play a considerable role in procurement. However, in the future Portugal may join the group of Member States having a centralised procurement structure with a high concentration of functions in a few institutions, since there are plans to create a "Unidade National de Compras".

Table. Features of the Public Procurement Structures in Summary

\begin{tabular}{|lll|}
\hline $\begin{array}{c}\text { Centralised } \\
\text { Structure }\end{array}$ & $\begin{array}{c}\text { Semi-centralised } \\
\text { Structure }\end{array}$ & $\begin{array}{c}\text { Decentralised } \\
\text { Structure }\end{array}$ \\
\hline Bulgaria & Austria & Finland \\
Cyprus & France & Portugal \\
Czech Republic & Germany & \\
Estonia & Ireland & \\
Hungary & Italy & \\
Latvia & Luxembourg & \\
Lithuania & Slovenia & \\
Malta & Sweden & \\
Poland & United Kingdom \\
Romania & & \\
Slovak Republic & & $\mathbf{2}$ \\
\hline 11 & $\mathbf{9}$ & \\
\hline
\end{tabular}




\subsection{Examples of Decentralisation in the Public Procurement Structure}

In a vertical public procurement structure, institutions and bodies at the level below the government level may carry out some procurement functions. Two categories of decentralisation need to be differentiated. First, central procurement bodies may have local offices outside their main headquarters. The most notable example is the Slovak Republic, where three local offices of the OPP carry out certain advice and training functions. Second, the Member State may be decentralised with regard to public procurement. In the federal Member States - Austria and Germany - and in Member States with devolved government - such as the United Kingdom, with the Scottish Parliament and the Assemblies in Wales and Northern Ireland, or Portugal, with the autonomous governments of the Azores and Madeira - often the federal states or units also have procurement institutions that carry out limited, or even quite extensive, procurement functions. Moreover, in many Member States the regions, provinces, districts, and municipalities may have similar bodies, which are either centralised or decentralised.

In Austria and Germany the federal states (regions) participate in the preparation of federal legislation through the "Federation States' Working Group" (Austria) and the Procurement Committees (Germany), the state ministries of finance, economy, and works provide advice to their governments and tenderers, the state (regional) civil service academies organise some training activities, and the state (regional) courts of audit carry out monitoring functions. The German State of North Rhine-Westphalia maintains a blacklist of tenderers. In Italy the regions, provinces, and municipalities all have procurement units that carry out some of the relevant functions. Similarly, the devolved parts of the United Kingdom and Portugal have their own public procurement institutions.

The Italian Public Works Authority has local branch offices without a separate legal personality. These offices provide advice, organise training, and gather information on a local basis. The functions of dependent branch offices are therefore rather limited. By contrast, the procurement institutions of states, regions, or municipalities may carry out a wider range of activities, including the development of local procurement policy, administration and monitoring functions, publication and information functions, advisory functions, and training and research functions.

\subsection{Absence of some Public Procurement Functions}

While many Member States have a central procurement structure covering most or all of the procurement functions described above, in some countries some functions are not covered by any institution. The regular monitoring of the public procurement system in order to measure its performance and assess its effectiveness, public procurement research, a comprehensive training programme for contracting officers, and even the development of a comprehensive procurement policy are the most notable examples of activities that are lacking in some Member States. On the other hand, essential functions - such as the preparation of legislation, international co-operation, provision of advice to contracting authorities, and publication - are covered in all Member States.

\subsection{Corporatised Procurement Functions}

In some Member States a number of procurement functions have been corporatised. Such a company may be fully or partly owned by the government, and the government normally supervises the company to a certain extent. The tasks covered by these companies may include central purchasing, facilitation of framework agreements, publication of contract notices, training, and administration of qualification lists, but it will not include core procurement functions. The rationale for these arrangements may differ from one Member State to another, but normally the 
advantages of a corporate model following private law relate to the commercial nature of these operations, with often special revenue and cost structures, contracting obligations, need for salary differentiation etc., which are difficult to create within the administrative structure.

For example, in Austria the public company Bundesbeschaffung $\mathbf{G m b H}$ (BBG) acts as a central purchasing unit under the Ministry of Finance. The BBG also facilitates framework agreements. In 2004 it set up an e-procurement procedure.

Together with the publicly owned company, Edita Plc, the Finnish Ministry of Trade and Industry developed a new procurement notification Internet service for below and above EU threshold procurement. This Internet service is operated by Edita Plc. In addition, commercial training organisations, most notably the government-controlled HAUS Ltd. (60\% owned by the state), offer a selection of training courses to the public sector, utilities sector and tenderers. HAUS Ltd. is subordinated to the Ministry of Finance. Finnish municipalities have a similar training company, called Efeko Ltd. Finally, Hansel Ltd is a private company, owned $100 \%$ by the state, which operates on a non-profit basis. The company acts as a central purchasing body and establishes and administers framework arrangements for the procurement of products and services. Hansel Ltd. is part of the administrative branch subordinated to the Ministry of Finance.

In Germany qualification lists with regard to works contracts are administered by the "Verein für die Präqualifikation von Bauunternehmen", a joint association of contracting entities, tenderers and business organisations for the prequalification of building companies. In Luxembourg contracts are published in private national newspapers, and in Sweden private companies, such as Allego or Opic, are given the task of publishing contracts.

\section{Institutional Models and Internal Organisational Design of the Main Public Procurement Bodies ${ }^{2}$}

With reference to the methodology section above, please note that the study does not make any specific reference to the nature of the contracts falling under the responsibility of central public procurement bodies, which may have had an impact on the conclusions made in the present section. This is in particular relevant to Member States where the regulatory responsibilities for concessions are, from an organisational point of view, handled separately from those bodies in charge of the regulation and monitoring of public procurement contracts.

This section of the comparative overview will discuss the various institutional models in place in Member States, in particular with regard to the key central public procurement bodies and how these bodies are organised in broad terms. The internal organisation of these bodies can differ considerably in terms of legal foundation, subordination and status, and basic organisational and decision-making structures. However, there are also considerable similarities.

\subsection{Legal Foundation}

The notion of legal foundation of a central public procurement body describes the provisions of a legal document establishing the institution and regulating its objectives, functions, organs and authority. The constitution, an act of parliament or a law, a royal or presidential decree, a ministerial decree, or custom can form the legal foundation of the central procurement organisation. Moreover, the legal foundation may be spread over various legal instruments, in particular when procurement functions are assigned to a number of procurement bodies. The 
legal foundation of procurement bodies forming an integral part of a government ministry is normally part of the general law regulating the organisation and procedures of the government. For example, the procurement functions of the Estonian Ministry of Finance are regulated in the Government of the Republic Act, those of the French DAJ by a Decree of the Prime Minister, and those of the Latvian Electronic Procurement State Agency in the Statute of the Cabinet. In contrast, the legal foundation of specialised public procurement offices or agencies is often regulated in the public procurement law. This is the case, inter alia, of the Bulgarian PPA, the Hungarian Public Procurement Council, the Italian Public Works Authority, the Latvian Procurement Monitoring Bureau, the Polish Public Procurement Office, and the Slovak Office for Public Procurement. The Czech Office for the Protection of Competition has its legal foundation in the Constitution, the Law of Government Organisation, the Public Contract Act, and the Concessions Act. The legal foundation of the United Kingdom Office of Government Commerce is a ministerial decree, whereas that of the Italian CONSIP is a legislative decree and two ministerial decrees. The legal foundation of the Maltese Department of Contracts is the general Financial and Audit Act. The legal foundation of corporatised central procurement bodies, such as the Austrian BBG and the Finnish Hansel Ltd., is often regulated in company law, together with a law or decree authorising the company to carry out certain procurement functions. The significance of the legal foundation of the central procurement body is related to the involvement of the respective parliament and the independence of the respective government resulting from this involvement. If the institution is regulated by a ministerial decree or by the internal statute regulating the organisation and procedures of the government, a minister or the government as a whole can change its functions or prerogatives and even abolish it without any involvement of the legislature. Such a legal foundation makes the respective institution a dependent part of the government. If the legal foundation of the institution is regulated in an act of parliament or in a formal law, then any changes to the functions and prerogatives of the institution are subject to the approval of parliament, unless the law authorises the government to introduce such changes. This dependence on an approval by parliament gives the institution a certain independence from the government, and this independence is even increased when the legal foundation is fully or partly regulated in the Constitution.

\subsection{Overview of Organisational Design and Decision-making Structures}

An attempt to briefly summarise and categorise the various institutional models in Member States is a complicated task, since there is a broad variety of organisational solutions in place. However, comparative analysis distinguishes between the internal structures of the main procurement bodies in the following terms:

1. Basic frameworks of management and decision-making structures (how these main bodies are organised, main set-ups and powers, how management is appointed, reporting lines, status and authority);

2. Executive and operational structure (how the operational level is organised, main functions and tasks). 
GENERIC INSTITUTIONAL MODEL CENTRAL PUBLIC PROCUREMENT STRUCTURE

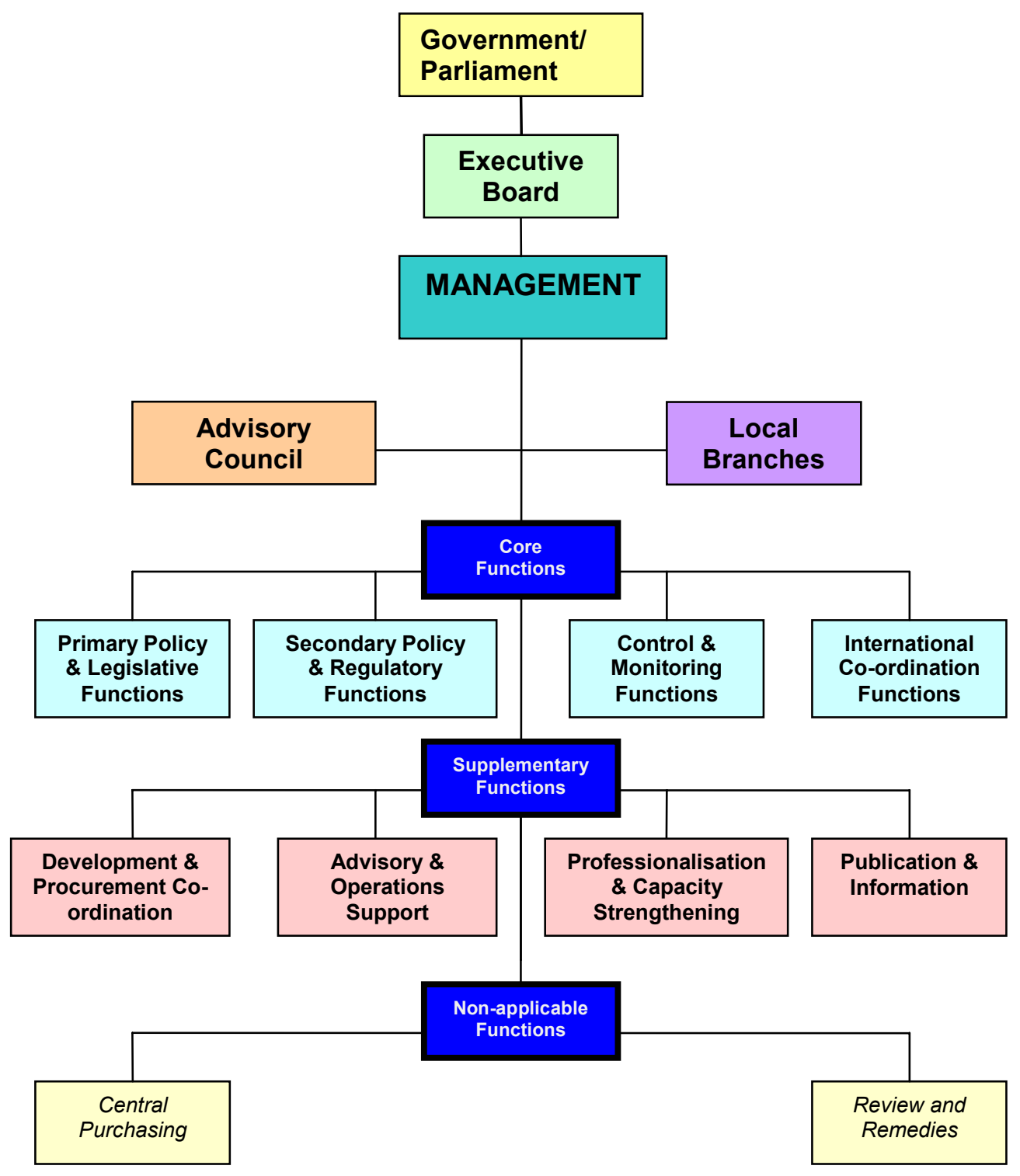

\subsubsection{Management and decision-making structures}

Most Member States follow a civil service model where central public procurement bodies are part of the civil service and are staffed by officials who are appointed, supervised and dismissed in the same way as all other civil servants. The leading civil servant has to report to his/her superiors in the government.

The Bulgarian Public Procurement Agency is managed by an executive director whose contract is signed, amended and terminated by the Minister of Economy and Energy in co-ordination with the Prime Minister. The Director General of the Estonian Public Procurement Office, who is appointed by the Minister of Finance, signs the decisions on protests and organises the work of the Office. The Head of the Latvian Procurement Monitoring Bureau represents the Bureau, decides on spending, issues internal guidelines, and appoints and dismisses officers and 
employees. The Director of the Latvian Electronic Procurement State Agency directs the work of the Agency: manages the day-to-day running of the Agency, prepares a strategy, represents the Agency, recruits and dismisses employees, and is responsible for allocating financial resources. The director is appointed by the minister after an open competition, which is published in the official gazette. The Director of the French DAJ is appointed by decree and reports to the Minister of Economy, Finance and Industry. There is a head of department of the Slovenian Department for Public Procurement, Public Utilities and Concessions. The Procurement Policy Division of the United Kingdom Office for Government Commerce is overseen by a senior civil servant, supported by a Divisional Management Office, who reports to one of the executive directors sitting on the OGC management board. Similarly, the heads of the respective procurement institutions in Austria, Germany, Luxembourg and Malta are civil servants.

In some Member States the central public procurement body is managed by a strong president or chairperson. The appointment and termination of office of such a strong person is a crucial factor in the relative importance of public procurement in the institutional structure of the government. The defining characteristic of this model is that the procurement management is not appointed by a particular minister but by the head of the government or the head of state, or even by parliament. A limited number of Member States follow this model, namely Cyprus, the Czech Republic (Office for the Protection of Competition), Poland, Romania and the Slovak Republic.

The Cypriot PPD is a Directorate within the Treasury of the Republic, which is an independent service (that is not under any ministry) headed by the Accountant General, who is appointed by the President of the Republic and cannot be removed from office until retirement. The Czech Office for the Protection of Competition is headed by a chairman who is appointed by the President of the Republic on a proposal by the government for a term of six years. The Romanian National Authority for Regulating and Monitoring Public Procurement is headed by a president and a vice-president under the control of the Prime Minister.

According to the Polish Public Procurement Law, the President of the Public Procurement Office is to be appointed by the Prime Minister from among candidates selected in an open competition. Only a person with a university degree and knowledge of the public procurement system is eligible. The term of office is five years, renewable once. He/she remains in office until the appointment of a successor. The independence of the President of the PPO has created a strong position for public procurement in Poland.

The Slovak Office for Public Procurement is headed by a chairperson, who is appointed and removed by the government. A deputy chairperson is appointed and removed by the government following a proposal by the chairperson. For both the chairperson and his/her deputy the term of office is five years, renewable once. According to article 111 of Act No. 25/2006, the term of office of the chairperson or deputy chairperson is to terminate upon expiry of his/her term, upon resignation from the office, upon dismissal from the office by the Slovak Government, or upon death or declaration of death. The government is to dismiss the chairperson or deputy chairperson when he/she has been lawfully convicted of an offence, has been deprived of his/her legal capacity by a lawful decision of a court or had his/her legal capacity restricted; if he/she holds an office or performs an activity that is incompatible with the office of chairperson or deputy chairperson; or if he/she has not exercised his/her functions for a period exceeding six successive calendar months. The government may suspend the execution of functions of the chairperson or deputy chairperson if criminal prosecution has commenced against him/her relating to the execution of his/her functions. Thus, according to the law, the leading organ of the Office for Public Procurement can only be terminated in certain prescribed cases and not simply because it has lost the confidence of the government. This legal protection represents a considerable enhancement of the office of chairperson. As in the case of Poland, the 
independence of the chairperson, guaranteed by law, has created a strong position for public procurement in the Slovak Republic.

There may be one or more deputy chairpersons or vice-presidents, either appointed by the head of the central public procurement body or elected or appointed from outside. The Executive Director of the Bulgarian PPA appoints the Secretary General, who directs, co-ordinates and controls PPA functioning according to secondary legislation and to the requirements set by the Executive Director. The Cypriot Public Procurement Directorate is headed by the Deputy Accountant General, who is a professional accountant. A deputy head represents the Latvian Procurement Monitoring Bureau in the absence of the head. The current two vice-presidents of the Polish Public Procurement Office are to be appointed and recalled by the Prime Minister at the request of the President of the PPO.

In other Member States, the central procurement body has a superior governance layer in the form of a public procurement council, committee or board. Hungary, Italy and Sweden follow this model. In the Hungarian case, the chairperson is elected by the Public Procurement Council. The Council is an autonomous administrative body and, according to the Act on Public Procurement, is subordinated only to parliament. Its members are appointed by representatives of the three stakeholders - tenderers, contracting entities, and persons representing public interests - in equal proportions. The Act defines the organisations/persons entitled to appoint Council members. Members elect a president for a five-year term of office with a $2 / 3$ majority and a vice-president for two years with a simple majority. Members of the Council, with the exception of the president, are not employed full-time. The Italian Public Works Authority has a chairperson and four members appointed jointly by the Speaker of the Senate and the Speaker of the Chamber of Deputies. The chairman of the board is elected by the members themselves. Each member remains in office for a five-year, non-renewable term. The Italian CONSIP has a board of directors nominated by the Ministry of Economy and Finance and composed of nine members, including the chairman and the CEO. The chairman is responsible for strategic development, institutional relations and communication, whereas the CEO is responsible for activities in general. The Swedish NOU is a national board and its members are appointed by the government upon proposals by the various stakeholders. The entire board, with its eight members, is the collective head of the NOU in matters of policy and interpretative statements within its mandate. The members are representatives of both contracting authorities and tenderers. The chairman is a judge from the Administrative Court of Appeal. The board meets once a month. The parliamentary appointment of the heads of the Hungarian and Italian institutions considerably enhances their independence from their respective governments.

Procurement bodies with a collective governance structure, as in Hungary and Sweden, have full-time executive bodies within their organisational structures. The working body of the Hungarian Public Procurement Council is the Secretariat, which is supervised by the Secretary General and structured into various units according to the specific tasks of the council. The Secretary General was appointed by the council in 1995 with an indefinite term of office. The day-to-day running of the Swedish NOU is also managed by a secretariat headed by a director.

A council or board may also act as a consultative organ of the central procurement body. It may represent the various stakeholders in the public procurement system, such as the government, parliament, industrial organisations, trade unions or academia. For example, the Polish Public Procurement Council is an advisory body of the President of the PPO. It is composed of 10 to 15 members appointed by the Prime Minister; there are currently 14 members. Parliamentary groups, national self-government organisations, and national entrepreneurs' organisations propose candidates to the Council. The Prime Minister appoints Council members. The Chairperson of the Council is appointed by the Prime Minister from among its members. The Vice-Chairperson of the Council is appointed by the Council from among its members. The 
Council is to express its opinions on particularly important matters concerning the public procurement system, as presented to it by the President of the PPO; give its opinion on normative acts concerning public contracts; give its opinion on the annual reports of the President of the PPO concerning the functioning of the public contracts system; establish the principles of professional ethics of persons performing tasks specified in the Public Procurement Law within the public contracts system; and give its opinion on structures resulting from the check conducted by the President of the PPO. The Romanian National Authority for Regulating and Monitoring Public Procurement also has such an advisory board. The Hungarian Public Procurement Council and the Swedish NOU also represent the stakeholders of the public procurement system, but in contrast to Poland, they are the principal decision-making bodies of their institutions.

\subsubsection{Executive and operational structures}

The executive functions of the central public procurement body reflect the tasks attributed to it, as outlined in previous sections of this study relating to the main functions normally found within these central procurement structures.

The Bulgarian Public Procurement Agency has three main subdivisions: Financial and Legal Directorate; Monitoring, Analyses and Methodology Section; and Electronic Database. The Cypriot Public Procurement Directorate has two main sub-sections: the Policy and Development Unit (PDU) and the Monitoring and Control Unit (MCU). The PDU is responsible for drafting legislation, standard tender documents and standard contract documents, and for developing general guidelines. This unit is also in charge of the organisation of a national training programme for the public sector and the utilities sector. The MCU is in charge of the preparation of guidelines and instructions, assistance and monitoring of contracting authorities, and collection of statistical and other data. The MCU also monitors the observance of the Cypriot public procurement law, for example with respect to the use of exceptions, extensions and accelerated procedures. The help-desk function is exercised by the MCU, which provides first-level support to contracting authorities in explaining public procurement legislation. The Estonian PPO has two main sections: the Department of Supervision and the Registry Department. The former performs the duties related to the enforcement and remedies function and the control and monitoring function. The latter exercises the publication and information function. The public procurement subdirectorate of the French DAJ comprises three units: "general legislation and international issues", "advice to public purchasers", and "prospective and technical issues". The Hungarian Public Procurement Council has a Legal Unit, a Unit of International Relations and Training, and an Editorial Board, responsible for the publication of notices in the bulletin and communication of notices related to community procedures to the EU Official Journal, revising all notices from the point of view of public procurement legislation, returning notices with missing data, and operating the electronic notice management system and the Internet homepage of the Council. The Economic Analysis Group takes care of the management and analysis of public procurement statistics; the Financial Unit and Manager of Human Resources plans the budget of the Council, organises consultations with the Ministry of Finance, and implements and controls the approved budget. Finally, the Internal Controller conducts financial audits in the organisation.

The Italian Public Works Authority (PWA) is divided into three main units. The Technical Secretariat supports all of the PWA activities through the preparation of interpretative documents or regulations. The Inspection Service represents the operational branch of the PWA; it conducts controls and makes inquiries in the area of public works. The Public Works Observatory electronically collects data and information concerning public works. In addition, it formulates standardised costs and provides statistics as well as cost-benefit analysis to support the PWA's activity. CONSIP is divided into seven directorates. The Control and Finance Directorate is 
responsible for accounting management, balance and budget elaboration, Treasury transactions, elaboration of quarterly statements, management control, acquisition management, sub-contract accounting management, real estate, support services management, and industrial safety. The Legal Unit and the Corporate Affairs Directorate cover the granting and legal management of tender awards; tender database management, management of the sub-contracting administration, and legal support to corporate activities. The General Director is responsible for IT direction and DARPA direction. The activities of the General Director are supported by the Directorate for Operations. The latter is in charge of project management, management and monitoring of contracts, project assurance support, study of qualitative standards for goods and services, definition of guidelines in auction designing strategy, and tools and methods for the planning of activities. The Public Finance Directorate has responsibility for promoting and managing all projects and services of the Department of the Treasury, the State General Accounting Department and the General Accounting Office. The Information Systems Directorate is responsible for promoting and managing all projects and services of the Ministry of Economy and Finance and the Ministry Office. DARPA promotes the rationalisation programme on public expenditure.

In the Latvian Procurement Monitoring Bureau (PMB), there are three departments and the Complaints Review Commission (CRC). The Legal Department examines complaints of tenderers and represents the PMB in court in cases where decisions of the CRC are subject to appeal. The Methodology Department consists of a director and three divisions: Methodology, Legislation and European Issues, and Control. The Information Department consists of a director and two divisions: Procurement Announcement and Statistics, and Procurement System Development. The CRC deals with complaints of tenderers and decides on the permission or prohibition to enter into a procurement contract.

The Polish Public Procurement Office (PPO) has four departments. The Legal Department provides both internal and external legal services for the PPO through four units: Legislation, Legal Opinions, Administrative Decisions, and European Law. The Control Department carries out the tasks related to control powers of the President of the PPO provided for in the PPL and organises the co-operation of the PPO with other control institutions, such as the Supreme Chamber of Control and regional audit chambers. The department is divided into four units: Ex ante Control of Contracts for Supplies and Services; Ex ante Control of Contracts for Works; Ex ante Control of Contracts for Utilities; and Ex post Control. The Training and Publications Department is responsible for training events, dissemination of training materials, and editing of the Public Procurement Bulletin (PPB). The tasks of the department are divided between its two units: the Training and Educational Publications Unit and the PPB Unit. The International Co-operation, Studies and Analyses Department is responsible for the international contacts of the PPO and its co-operation with relevant authorities in other countries and in international organisations dealing with public procurement issues. The department gathers and disseminates information about foreign and international public procurement provisions and procedures. The department also analyses the functioning of the Polish public procurement system, the procurement market and its prospective development. It prepares annual reports on the functioning of the public procurement system, which are then submitted to the Council of Ministers (two staff). The department also prepares statistical reports that are submitted to the European Commission pursuant to the relevant provisions of the EU Directives. The department collects statistical and other data. The Bureau of Appeals carries out tasks related to appeal proceedings under the PPL and provides services for the appeal panels. Complaints against procurement decisions must be made to the relevant contracting entities (first instance) before the independent appeal panels of the PPO review the case in a second instance.

The Slovak Office for Public Procurement (OPP) is subdivided into the Office of the Chairman, Office of the Deputy Chairman, Division of Legislation and Methodology, Division of Journal and 
Lists, Division of Internal Provisions and Decisions on Protest, Division on Inspection, Department of European Integration and International Co-operation, Office of State Service, Division of Economy and IT, Commissions on Remedies, and Appeal Board of the Office of the Deputy Chairman.

\section{Administrative Capacity of Central Public Procurement Structures}

\subsection{Defining the Concept of Administrative Capacity}

One of the main objectives of this study is to discuss the issue of administrative capacity within central public procurement structures. New EU Member States and EU candidate countries have been or are confronted with this issue as one of the key criteria under the public procurement chapter for accession to the EU. It is not sufficient for a candidate country to simply comply with the acquis; it is expected to set up in a broader sense a fully safe and efficient system of public procurement. Acceding countries should demonstrate that they have a satisfactory degree of administrative capacity at central government level to implement national legislation transposing the EC Directives, to monitor public procurement operations effectively, and to meet all other obligations under the EC Directives and the EC Treaty. These obligations imply establishing appropriate institutions and mechanisms, including those dealing with remedies, and ensuring that these institutions are adequately staffed and have the capacity to exercise all of their functions efficiently, which may cover a wide range of both core and supplementary functions, as discussed above. However, administrative capacity should not only be defined in this narrow sense, but needs to be seen beyond the position of capacity exercised by the central procurement bodies so as to include the accumulated administrative capacity that is organised and available within the public administration to support public procurement operations in a Member State. According to this wider definition, administrative capacity is available and provided by numerous actors in a society, including actors in the private sector. In particular, the exercise of some of the supplementary functions, such as professionalisation and capacity-strengthening, are shared between many actors in a Member State, while the core functions are normally the responsibility of the main central procurement bodies. This study does not analyse administrative capacity in this broader meaning, but limits its attention to discussing capacity at central government level. However, it needs to be underlined that the study makes no attempt to assess the capacity of individual Member States, but only to provide an overview of how Member States have chosen to organise and staff their main procurement bodies. The need and availability of capacity within these main bodies is dependent on a number of factors, such as the size of the economy, the number of contracting entities and procurement contracts, the administrative structure of a Member State, as well as, of course, the extent to which public procurement is prioritised by a national government.

The notion of administrative capacity at central level addresses the question of whether the central public procurement bodies of a Member State have the human, financial and other resources required to carry out the key public procurement functions outlined in the introduction above. This question also touches on the issue of how central public procurement bodies carry out these functions. The administrative capacity of Member States differs considerably, ranging from small units situated in national ministries to public procurement offices with several hundred employees or civil servants. The educational background of the staff working in the central procurement institutions is particularly important in the context of a highly regulated policy field affected by EU policies.

As outlined in previous sections of this study, the central public procurement bodies of Member States have to carry out a wide range of functions. Many of these functions are directly connected to membership in the EU. Primary and secondary legislation needs to be prepared in 
a regulatory environment of almost permanent reform, as required by the legislator and the case law of the European Court of Justice. Moreover, the central procurement body has to co-ordinate the national contribution to this legislative process through advisory committees and specialised advice to the national government. Statistical material needs to be collected and communicated. The European Commission and the central public procurement organisations of other Member States need to have a permanent national contact point. Consequently, a national central public procurement structure with adequate administrative capacity is essential to carry out the core functions and to fulfil the requirements of EU membership in the area of public procurement. However, a Member State also needs the administrative capacity to carry out the numerous supplementary functions in view of their indirect, but very significant, effect on the implementation of public procurement legislation in practice and on the support they provide to the development of the national public procurement system.

\subsection{Administrative Capacity of Central Procurement Bodies}

The administrative capacity of public procurement organisations in Member States comprises human resources, including staff size, composition of staff and their educational backgrounds; financial resources; and management status.

\subsubsection{Staff size and educational backgrounds}

The human resources of the central public procurement organisation are the central issue in the context of administrative capacity. The staff size - the number of people working for the main central procurement body and other relevant institutions - is the starting point (quantity). If the institutions are constantly understaffed, their human resources capacity is not sufficient to carry out their numerous functions effectively. Moreover, the educational background of the staff is important. The number of lawyers, economists, political scientists, former practitioners, engineers or accountants is as important as the training of support staff. In addition, the role of continuous education, either internally or externally, will play a certain role. Similarly to the financial resources addressed below, the relation between the size of the national public procurement market and the complexity of tasks attributed to the central procurement organisation and its staff size are other relevant considerations. The staff sizes of central procurement bodies vary in Member States. Moreover, since many of the relevant bodies deal with many issues in addition to the public procurement functions outlined above, it is not always clear how many people are actually working on core and supplementary central public procurement functions.

The Austrian Section for Procurement Law of the Constitutional Service of the Federal Chancellery has a staff of four full-time civil servants with law degrees. The publicly owned Bundesbeschaffungs $\mathrm{GmbH}$ has 58 staff: one civil servant and 57 employees. The five persons working in its Legal Department have a university degree in law. In the Purchasing Department staff have either a technical or commercial background or a university degree. The total number of staff in the Public Procurement Agency of Bulgaria is 38, which comprises both civil servants and employees, of whom 34 have master's degrees (19 in economics, nine in law and six in IT). In the immediate future the staff will be increased to a number in the 50s. The Cypriot Public Procurement Department employs 14 people, excluding clerical staff. There are five professional accountants, six university graduates in economics and engineering, and three LCCI Higher holders.

The Legal Department of the Czech Office for the Protection of Competition has six employees, the Public Procurement Section 30 employees, the Appellate Commission six employees and about 20 external specialists, the Organisation and Finance Department ten employees, and the Department of European Integration and International Relations also ten employees. Most 
employees have a university degree in law or economics. Four civil servants in the Estonian Ministry of Finance deal specifically with public procurement issues, and 18 staff are working in the Public Procurement Office. In Finland about four civil servants in the Ministry of Finance and 50 staff in the private company Hansel Ltd. work on procurement issues.

In France about 40 people work for the Public Procurement Directorate and 18 for the State Commission. In the procurement sub-directorate of the Department for Judicial Affairs, Ministry of Economy, Finance and Industry, 30 civil servants have university degrees. In 2005 the Hungarian Public Procurement Council had 23 members and there were 33 staff in the Secretariat. Most staff members are civil servants but some are employed on a part-time basis under general or special assignment conditions. According to the Hungarian Act on Civil Servants, a secondary school diploma is required, and in the case of the post of administrator a medium-level vocational diploma is required. A civil servant must pass a public administration professional examination and a lawyer must pass a legal professional examination within three years after employment. Public procurement commissioners need a higher education diploma and three years of professional experience, and they must pass a legal or public administration professional examination. In 2005 the total number of staff working in the Hungarian Public Procurement Arbitration Board and its secretariat was 79 persons. The Irish National Unit for Public Procurement Policy currently has 10 to 12 staff members: a head of unit, a construction professional adviser, five staff at mid-management level, and four to five staff at clerical level.

In 2006 the Italian Public Works Authority has a staff of 237 civil servants, of whom the majority has a degree in engineering, law or economics. The percentage of staff familiar with EC law is about 70 per cent. CONSIP has about 500 employees, 355 of whom have university degrees. The 32 staff of the Latvian Procurement Monitoring Bureau comprise 18 civil servants and 14 employees, whereas the Electronic Procurement State Agency has a staff of 32, of whom 18 are civil servants and 14 are employees. Approximately half of them have a legal background and about a quarter of them have an educational background in economics. All are familiar with public procurement, except for the business and administrative personnel and the accountants. Two civil servants in the Luxembourg Ministry of Public Works focus specifically on public procurement.

The President of the Polish Public Procurement Office is supported by a staff of 115 . All civil servants and almost all employees of the PPO have university degrees, and many are lawyers. In particular the three staff members in the European Law Unit and four members of the staff of the International Co-operation, Studies and Analyses Department are familiar with EC law. The entire staff of the Legal Department, Control Department, International Co-operation, Studies and Analyses Department, and Training and Publication Department are familiar with the Public Procurement Law. Financial and technical aspects of procurement are known to some staff with experience in contracting authorities. Nine civil servants work for the Portuguese Direcção Geral do Património.

In Romania, the National Authority for Regulating and Monitoring Public Procurement (NARMPP) currently has a full-time staff of 70 , but the total number of positions to be filled according to the law is 125 . 90 per cent of the staff have a university degree in various subjects, and they include economists, lawyers and engineers. The public administration rules for promotion apply to the NARMPP. All staff of the NARMPP are familiar with the provisions of public procurement legislation. About 130 staff members in the Ministry of Finance are working on ex ante control in the area of public procurement. The Slovak Office of Public Procurement has a staff of about 110, of whom 90 are civil servants and 20 are employees; nearly all of them have a college or university education. Eight civil servants with an academic background are working for the Slovenian Department for Public Procurement, Public Utilities and Concessions. 
The secretariat of the Swedish NOU has nine to ten employees (lawyers and economists with university degrees), and two civil servants in the Ministry of Finance are specifically working on public procurement issues. The United Kingdom Office of Government Commerce currently employs around 500 people, mostly civil servants but also consultants, but of these only a small proportion is engaged in central procurement policy work - around 25 in all. Their educational background varies. Most staff received professional training in procurement and most are familiar with EC law and public procurement law. A high proportion of staff members is familiar with the financial and technical aspects of procurement.

\subsubsection{Means of financial revenue}

Financial resources concern the budget of the central public procurement institutions but also the sources of their income. Many institutions receive their income from the general budget, for example the budget allocations of the ministry to which they are attached. Other offices may have their own sources of income, for example through fees payable for the publication of contracts or even through some form of "tax" on every contract. The size of the budget is not the only crucial issue here. The size of the national public procurement market and the complexity of the tasks attributed to the central procurement organisation are other relevant considerations.

In 2005, the budget of the Bulgarian Public Procurement Agency was drafted internally and then submitted to the Ministry of Economy and Energy for approval. The budget of the Czech Office for the Protection of Competition is mainly part of the government budget, but the person who is filing a complaint used to have to provide a deposit and at the same time pay a now abolished administrative charge. The annual budget of the Estonian Public Procurement Office is part of the general state budget. The annual budget of the public procurement subdirectorate of the French DAJ is part of the state budget.

In 2005 the budget of the Hungarian Public Procurement Council was part of the annual budget law. The budget is prepared through consultations between the staff of the PPC secretariat and the Ministry of Finance and then adopted by parliament. However, the income does not originate from the ministerial budget alone, but also from fees for publication and fines $(50 \%$ of the income). The public administration service fees related to the administration of various lists (list of official public procurement consultants, official list of approved contractors, list of conciliators) and fees payable for starting review procedures are other sources of income for the PPC. In addition, income from the sales of the bulletin also goes to the Council (although this income is substantially less than the costs of publication).

The budget assigned to CONSIP in Italy is part of the general ministerial budget and results from a fixed quote covering the fixed costs of the programme (i.e. personnel) and a variable quote covering the innovative strategic project costs. The budget of the Latvian Procurement Monitoring Bureau is part of the state budget. The budget for running the Maltese Department of Contracts is financed from the general governmental budget. Budget estimates are prepared by September of each year and forwarded to the Ministry of Finance. The budget is adopted according to the country's priorities. The revised budget is approved by parliament at the end of the calendar year.

The original budget for the Polish Public Procurement Office is part of the state budget and prepared in accordance with the budget law. The costs of the appeal proceedings are covered by the compulsory registration fees. The budgets of the various Portuguese procurement institutions are part of the state budget. The budget of the Romanian National Authority for Regulating and Monitoring Public Procurement is part of the general state budget. The budget of the Slovak Office for Public Procurement is a separate section of the state budget. Fees, fines and bails are revenues of the state budget. 
The finances of the Slovenian Department for Public Procurement, Public Utilities and Concessions are part of the general budget of the ministry and government. Operations of the Swedish NOU are financed through the general governmental budget. The Public Procurement Directorate (PPD) of the United Kingdom Office of Government Commerce (OGC) has its operations financed by the state budget, which covers all running costs; only a proportion is devoted to outside sourcing of goods and services. The OGC annual corporate budget is agreed with HM Treasury following discussions on estimates of the levels of resource required to deliver its business plan, which is a composite of the business plans of the individual organisational units. Individual business plans and budgets are considered by the OGC Investment and Implementation Board, which ensures that resources allocated to the various elements of the organisation are in agreement with corporate priorities. The PPD budget is agreed in the same way as for other organisational units of the OGC.

As seen above, the central public procurement institutions in most Member States are financed through the general governmental or ministerial budget. In all Member States the greater part of their financing is provided through the general governmental or ministerial budget. In Hungary and Poland additional income is obtained through fees and deposits that have to be paid for review proceedings. However, this supplementary income means that the institution carrying out central public procurement functions, as defined in this study, must also carry out the connected function of review. Fees can also generate income when the central public procurement institution is responsible for keeping qualification lists or publishing contract notices.

\section{A Changing Public Procurement Environment}

This section provides a broad overview of factors that may influence public procurement systems in Member States and discusses possible implications of this change process.

As discussed earlier, the study reveals the existence of a fairly clear division line between the type of organisational structure in place in the group of new Member States compared with those in place in "old" Member States. Generally, the majority of countries that recently joined the EU has established comparably strong central organisational bodies within their governmental structures. These bodies have been granted an extensive degree of responsibility and co-ordinating roles covering core functions as well as a wide range of supplementary functions. In "old" Member States, supplementary functions, in particular support tasks, are frequently organised in a decentralised manner.

As a starting point for further discussion, one may wonder why the public procurement systems, institutionally, have developed so differently in the two groups of Member States. One plausible explanation could be the differences in circumstances and conditions under which the public procurement systems were formed and developed within new Member States compared with the more evolutive process that has characterised institutional development in "old" Member States. Initially, the implementation of new and market-based public procurement legislation, often within an extremely short time frame, required an effective and quick mobilisation of support and efforts by the government in order to be successful. Therefore, governments generally realised that a prerequisite for an effective legal reform process was the availability of a centralised institutional solution, which would be granted the authority and assigned the tasks of co-ordinating, managing and supporting the implementation of public procurement legislation. The need for a strong focal point within the government structure was further accentuated once this group of countries achieved EU candidate status, thereby adding a set of further qualified obligations. The acceding countries to the EU had the obligation of transposing Community law in the area of public procurement as well. Equally important, they needed to strengthen central administrative capacity to ensure that the acquis would not only be correctly transposed but that public procurement legislation would be implemented efficiently. In contrast to this very quick and 
radical shift of systems, which resulted mainly in typically centralised institutional models, public procurement in "old" Member States has developed gradually over more than a century, which of course has led to the establishment of a variety of organisational models. For the most part they have maintained a fairly decentralised structure and organisation of public procurement. At the central government level, the "old" Member States have tended to rely on small legal and procurement policy functions, while supplementary functions, such as procurement advice and capacity-strengthening, have frequently been a shared responsibility with regional and local authorities and with many other actors, including in the private sector.

With this differentiation between new and "old" Member States as a basis for the continuing discussion, a number of important events within the area of public procurement have already occurred or are currently taking place. This process of change needs to be considered and dealt with effectively by governments, since these changes will have implications on how best to organise the institutional structure of the public procurement system. In particular, the following main developments need to be taken into account by Member States.

\section{Recent Legislative and Regulatory Development in the European Union}

With the adoption of EC Directives EC 2004/17 and 18, Member States were under the obligation to adopt national procurement legislation transposing the new Directives by 1 February 2006. The new Directives introduced a number of new instruments and mechanisms that reflected the growing need for increased clarity, modernisation, and simplification of the European legislative framework on public procurement. Although it is left to the discretion of Member States in some cases to decide whether to introduce a certain provision in the Directives, such as the competitive dialogue, the overall impression is that for the majority of Member States the new Directives may imply a considerable change in terms of how public procurement will be organised and conducted. They will not necessarily affect the way in which the typical regulatory and monitoring functions are organised within the public procurement structure, but rather the range of various support and co-ordinating functions. One main objective of the new legislative framework was to offer a higher degree of simplification in the procurement process and the availability of more options in the choice of procurement methods and this has definitely been achieved, but the effects of these changes will at the same time generate an increased complexity in most sectors of the public procurement system. The most apparent changes are the introduction of framework agreements, central purchasing bodies, electronic procurement, competitive dialogue, performance-based technical specifications, and environmental considerations. Some Member States had already incorporated some of the new procedures in national provisions, such as framework agreements and central purchasing bodies, but this category of Member States will not remain unaffected when it comes to revising procurement legislation, including implementing regulations, and deciding on how to organise these mechanisms most effectively.

\section{Technological Development}

The use of electronic means and methods on a wider scale in the various stages of the public procurement process will gradually be introduced and practised in public procurement, thereby replacing the current paper-based methods. There are also several other changes related to the rapid developments in the IT sector having an impact on the public procurement market, consequently generating a need for all Member States to carefully consider how this challenge should best be met and what kind of preparations should be made to most effectively adapt their procurement systems to new market conditions. Technological developments will produce a fundamental shift of practices and patterns in the manner in which public procurement will be executed in the future, but of course it is not possible at this stage to foresee all practical and operational consequences. However, some likely effects are foreseen, such as an enhanced need to develop central support functions with Internet-based guidance systems, creation of 
standardised systems for tender and contract documentation, design of improved and easily accessible Internet-based publication and information systems, and development of systems for co-ordination and joint co-operation between contracting entities.

\section{Increased Emphasis on Efficiency}

Public procurement operations, and subsequently also the procurement support structure, are also strongly affected by the ongoing efforts in many countries to redefine the role of the public sector by introducing new economic reform initiatives and measures to obtain more cost-effective solutions for the delivery of public sector services, such as deregulation, privatisation of public operations, use of concession arrangements, and public/private partnerships.

Together with the new instruments laid down in the EC Directives and increased efforts to increase efficiency and obtain "best value for money" in the public sector at all levels, greater emphasis will be placed on the need to create systems for co-ordinated purchasing and on the wider use of framework agreements, where appropriate, in order to exploit aggregate purchasing power and to obtain better prices, lower costs, and technical and functional standardisation of products and services delivered to the public sector.

\section{Continuous Professionalisation of the Procurement Function}

The combined effects of regulatory, technological and commercial developments should create a demand for increased professionalisation of the procurement function at operational level (in contracting entities as well as in private sector). Contracting entities will certainly face a more complex procurement environment, with a wider set of functions and responsibilities or at least a significantly different situation compared with traditional procurement tasks, which will in turn affect required competences and the choice of organisational and co-operative solutions. There will be a continuing demand for higher education as well as specialised training in public procurement in various disciplines and professions.

To be efficient, public procurement structures will need to be sensible to a changing procurement environment and take adequate steps for building appropriate institutional solutions for public procurement. In particular, a stronger support structure will be required, providing professional advice and capacity-strengthening.

The core regulatory and monitoring functions will remain within the central government administration, as may the advisory tasks closely associated with legislative and regulatory functions. However, the professional advice and operations' support functions may be organised centrally as well, but they will in addition be a shared responsibility and provided by many actors, including in the private sector. The information technology and publication functions could easily be executed outside the central level by specialised bodies, including those in the private sector. Professionalisation and capacity-strengthening functions could be a responsibility at the central level in terms of policies and strategic direction, but they will also be carried out by many bodies and actors.

\section{Summary of Main Conclusions}

The study indicates that there are both similarities and differences in the manner in which Member States have organised their central public procurement functions.

Firstly, for the purpose of the study these functions have been subdivided into two types of functions, namely core and supplementary. All Member States have chosen to organise the core functions - mainly policy and regulatory tasks - centrally at a high governmental level, while the situation is more mixed with regard to the supplementary or support-oriented functions. It appears that the group of Member States that recently entered the EU has preferred to organise their procurement structures in a more centralised manner, with a high concentration of functions 
assigned to a few central institutions, while the group of "old" Member States show a more diversified picture, with a wider distribution of functions to various bodies at different levels of the administration.

Secondly, the study discusses the issue of administrative capacity within the public procurement structure to fulfil effectively and efficiently all of the responsibilities related to managing a public procurement system at the central level. The study concludes that administrative capacity is not only linked to the level of staff and financial resources available within central procurement institutions, but needs to be more broadly defined. The total capacity of Member States to support public procurement operations on an accumulated basis may be strong if all actors in the society are included, so that this capacity is not limited to the level of central institutions. While the study conveys some interesting information on the amount of resources allocated at central level, at the same time it should be kept in mind that the size of central procurement institutions is dependent on a number of factors, such as the size of the economy and the number of contracting entities and procurement contracts, and does not necessarily reflect government priorities.

Thirdly, the study addresses the issues of organisation, subordination, status and legal foundation of central procurement bodies. Whatever organisational models are chosen, it appears that public procurement is usually the responsibility of the Ministry of Finance, Ministry of Economy, or Ministry of Works. The legal foundation is frequently the public procurement law or administrative law. Some Member States have established public procurement offices or agencies, which are given a more independent status directly under parliament or the government, while others act as departments within ministerial structures. Some functions of an operational nature are organised in publicly-owned firms.

Fourthly, the evolution of key procurement functions is briefly discussed in the light of a changing public procurement environment, which is gradually growing in complexity as an effect of the introduction of new procurement instruments and mechanisms, technological developments and stronger emphasis on efficiency in the delivery of public services. Any procurement structure will need to consider how to best achieve an increased professionalisation of the procurement function and meet the subsequent need to develop, in particular, the procurement support structure. It is therefore vital to find the appropriate global organisational model that strikes an effective and natural balance between the specificities of the functions involved and the requirements of these functions in terms of independence and interaction, while at the same time avoiding conflicts of interest. 


\section{ANNEX COMPARATIVE OVERVIEW OF PUBLIC PROCUREMENT STRUCTURES IN EU MEMBER STATES}

\begin{tabular}{|c|c|c|c|c|}
\hline Member State & $\begin{array}{c}\text { Key } \\
\text { Institutions }\end{array}$ & $\begin{array}{l}\text { Number } \\
\text { of Staff }\end{array}$ & Subordination & Main Functions \\
\hline $\begin{array}{l}\text { 1. Austria } \\
\text { (Semi- centralised } \\
\text { structure) }\end{array}$ & $\begin{array}{l}\text { Section for } \\
\text { Procurement } \\
\text { Law }\end{array}$ & 4 & $\begin{array}{l}\text { Federal } \\
\text { Chancellor's Office }\end{array}$ & $\begin{array}{l}\text { Drafting primary and secondary } \\
\text { legislation } \\
\text { International co-ordination function } \\
\text { Advisory functions } \\
\text { Monitoring and control functions } \\
\text { Information functions }\end{array}$ \\
\hline & $\begin{array}{l}\text { Federal } \\
\text { Procurement } \\
\text { Ltd. }\end{array}$ & 58 & Ministry of Finance & $\begin{array}{l}\text { Business development and } \\
\text { co-ordination } \\
\text { Central purchasing function }\end{array}$ \\
\hline $\begin{array}{l}\text { 2. Bulgaria } \\
\text { (Centralised } \\
\text { structure) }\end{array}$ & $\begin{array}{l}\text { Public } \\
\text { Procurement } \\
\text { Agency }\end{array}$ & 38 & $\begin{array}{l}\text { Ministry of } \\
\text { Economy and } \\
\text { Energy }\end{array}$ & $\begin{array}{l}\text { Drafting primary and secondary } \\
\text { legislation } \\
\text { Advisory and operations' support } \\
\text { functions } \\
\text { International co-ordination function } \\
\text { Monitoring and control functions } \\
\text { Publication and information } \\
\text { functions } \\
\text { Professionalisation and } \\
\text { capacity-strengthening functions }\end{array}$ \\
\hline $\begin{array}{l}\text { 3. Cyprus } \\
\text { (Centralised } \\
\text { structure) }\end{array}$ & $\begin{array}{l}\text { Public } \\
\text { Procurement } \\
\text { Directorate }\end{array}$ & 14 & Treasury & $\begin{array}{l}\text { Drafting primary and secondary } \\
\text { legislation } \\
\text { Advisory and operations' support } \\
\text { functions } \\
\text { International co-ordination function } \\
\text { Monitoring and control functions } \\
\text { Professionalisation and } \\
\text { capacity-strengthening functions }\end{array}$ \\
\hline $\begin{array}{l}\text { 4. Czech Republic } \\
\text { (Centralised } \\
\text { structure) }\end{array}$ & $\begin{array}{l}\text { Public } \\
\text { Investment } \\
\text { Department }\end{array}$ & 17 & $\begin{array}{l}\text { Ministry for } \\
\text { Regional } \\
\text { Development }\end{array}$ & $\begin{array}{l}\text { Drafting primary and secondary } \\
\text { legislation } \\
\text { Advisory functions } \\
\text { International co-ordination function } \\
\text { Monitoring and control functions } \\
\text { Publication and information } \\
\text { functions (partially) }\end{array}$ \\
\hline
\end{tabular}




\begin{tabular}{|c|c|c|c|c|}
\hline \multirow{6}{*}{$\begin{array}{l}\text { 5. Estonia } \\
\text { (Centralised } \\
\text { structure) }\end{array}$} & \multirow{5}{*}{$\begin{array}{l}\text { Public } \\
\text { Procurement } \\
\text { Office }\end{array}$} & \multirow[t]{5}{*}{19} & \multirow[t]{5}{*}{ Ministry of Finance } & $\begin{array}{l}\text { Advisory and operations' support } \\
\text { functions }\end{array}$ \\
\hline & & & & International co-ordination function \\
\hline & & & & Monitoring and control functions \\
\hline & & & & $\begin{array}{l}\text { Publication and information } \\
\text { functions }\end{array}$ \\
\hline & & & & $\begin{array}{l}\text { Professionalisation and } \\
\text { capacity-strengthening functions }\end{array}$ \\
\hline & $\begin{array}{l}\text { State Aid and } \\
\text { Public } \\
\text { Procurement } \\
\text { Unit, Public } \\
\text { Governance } \\
\text { Department }\end{array}$ & 4 & Ministry of Finance & $\begin{array}{l}\text { Drafting primary and secondary } \\
\text { legislation }\end{array}$ \\
\hline \multirow{10}{*}{$\begin{array}{l}\text { 6. Finland } \\
\text { (Decentralised } \\
\text { structure) }\end{array}$} & \multirow[t]{6}{*}{$\begin{array}{l}\text { Trade } \\
\text { Department }\end{array}$} & \multirow[t]{6}{*}{4} & \multirow[t]{6}{*}{$\begin{array}{l}\text { Ministry of Trade } \\
\text { and Industry }\end{array}$} & $\begin{array}{l}\text { Drafting primary and secondary } \\
\text { legislation }\end{array}$ \\
\hline & & & & $\begin{array}{l}\text { International co-ordination function } \\
\text { (shared) }\end{array}$ \\
\hline & & & & Advisory functions (shared) \\
\hline & & & & Monitoring and control functions \\
\hline & & & & Information functions \\
\hline & & & & $\begin{array}{l}\text { Professionalisation and } \\
\text { capacity-strengthening functions } \\
\text { (shared) }\end{array}$ \\
\hline & $\begin{array}{l}\text { Budget } \\
\text { Department }\end{array}$ & 2 & Ministry of Finance & Overall policy functions \\
\hline & Haus Ltd & 2 & Ministry of Finance & $\begin{array}{l}\text { Professionalisation and } \\
\text { capacity-strengthening functions } \\
\text { (shared) }\end{array}$ \\
\hline & \multirow[t]{2}{*}{ Hansel Ltd } & \multirow[t]{2}{*}{50} & \multirow[t]{2}{*}{ Ministry of Finance } & $\begin{array}{l}\text { Business development and } \\
\text { co-ordination }\end{array}$ \\
\hline & & & & Central purchasing function \\
\hline \multirow{4}{*}{$\begin{array}{l}\text { 7. France } \\
\text { (Semi- centralised } \\
\text { structure) }\end{array}$} & \multirow{4}{*}{$\begin{array}{l}\text { Public } \\
\text { Procurement } \\
\text { Department, } \\
\text { Directorate } \\
\text { for Legal } \\
\text { Affairs }\end{array}$} & \multirow[t]{4}{*}{40} & \multirow{4}{*}{$\begin{array}{l}\text { Ministry of } \\
\text { Economy, Finance } \\
\text { and Industry }\end{array}$} & $\begin{array}{l}\text { Drafting primary and secondary } \\
\text { legislation }\end{array}$ \\
\hline & & & & $\begin{array}{l}\text { Advisory and operations' support } \\
\text { functions }\end{array}$ \\
\hline & & & & International co-ordination function \\
\hline & & & & Monitoring and control functions \\
\hline
\end{tabular}




\begin{tabular}{|c|c|c|c|c|}
\hline \multirow[t]{3}{*}{$\begin{array}{l}\text { 8. Germany } \\
\text { (Semi- centralised } \\
\text { structure) }\end{array}$} & BMWi & 10 & $\begin{array}{l}\text { Federal Ministry of } \\
\text { Economy and } \\
\text { Technology }\end{array}$ & $\begin{array}{l}\text { Drafting primary legislation } \\
\text { Drafting secondary legislation } \\
\text { (shared) } \\
\text { International co-ordination function } \\
\text { Advisory functions } \\
\text { Monitoring and control functions } \\
\text { Information functions }\end{array}$ \\
\hline & $\begin{array}{l}\text { Bundesverwalt } \\
\text { ungsamt } \\
\text { (Federal office } \\
\text { for } \\
\text { administration) }\end{array}$ & 9 & $\begin{array}{l}\text { Federal Ministry of } \\
\text { Interior }\end{array}$ & Publication function \\
\hline & $\begin{array}{l}\text { Ministry of } \\
\text { Transport, } \\
\text { Building and } \\
\text { Urban Affairs }\end{array}$ & & & $\begin{array}{l}\text { Professionalisation and } \\
\text { capacity-strengthening functions } \\
\text { (shared with many) }\end{array}$ \\
\hline \multirow{6}{*}{$\begin{array}{l}\text { 9. Hungary } \\
\text { (Centralised } \\
\text { structure) }\end{array}$} & \multirow{4}{*}{$\begin{array}{l}\text { Public } \\
\text { Procurement } \\
\text { Council }\end{array}$} & \multirow[t]{4}{*}{35} & \multirow[t]{4}{*}{ Parliament } & $\begin{array}{l}\text { Advisory and operations' support } \\
\text { functions }\end{array}$ \\
\hline & & & & $\begin{array}{l}\text { International co-ordination function } \\
\text { Monitoring and control functions }\end{array}$ \\
\hline & & & & $\begin{array}{l}\text { Publication and information } \\
\text { functions }\end{array}$ \\
\hline & & & & $\begin{array}{l}\text { Professionalisation and } \\
\text { capacity-strengthening functions }\end{array}$ \\
\hline & \multirow{2}{*}{$\begin{array}{l}\text { Department of } \\
\text { Civil Law, } \\
\text { Codification } \\
\text { and } \\
\text { International } \\
\text { Private Law }\end{array}$} & \multirow[t]{2}{*}{4} & \multirow{2}{*}{$\begin{array}{l}\text { Ministry of Justice } \\
\text { and Law } \\
\text { Enforcement }\end{array}$} & $\begin{array}{l}\text { Drafting primary and secondary } \\
\text { (shared) legislation }\end{array}$ \\
\hline & & & & International co-ordination function \\
\hline \multirow[t]{4}{*}{$\begin{array}{l}\text { 10. Ireland } \\
\text { (Semi- centralised } \\
\text { structure) }\end{array}$} & \multirow{4}{*}{$\begin{array}{l}\text { National } \\
\text { Public } \\
\text { Procurement } \\
\text { Policy Unit }\end{array}$} & \multirow[t]{4}{*}{12} & \multirow[t]{4}{*}{$\begin{array}{l}\text { Department of } \\
\text { Finance }\end{array}$} & $\begin{array}{l}\text { Drafting primary legislation } \\
\text { Advisory and operations' support } \\
\text { functions }\end{array}$ \\
\hline & & & & International co-ordination function \\
\hline & & & & Monitoring and control functions \\
\hline & & & & $\begin{array}{l}\text { Professionalisation and } \\
\text { capacity-strengthening functions }\end{array}$ \\
\hline \multirow{6}{*}{$\begin{array}{l}\text { 11. Italy } \\
\text { (Semi- centralised } \\
\text { structure) }\end{array}$} & $\begin{array}{l}\text { Public Works } \\
\text { Authority }\end{array}$ & 237 & Parliament & Monitoring and control functions \\
\hline & \multirow{4}{*}{$\begin{array}{l}\text { CONSIP } \\
\text { (limited public } \\
\text { company) }\end{array}$} & \multirow[t]{4}{*}{500} & \multirow{4}{*}{$\begin{array}{l}\text { Ministry of } \\
\text { Economy and } \\
\text { Finance (owner) }\end{array}$} & $\begin{array}{l}\text { Advisory and operations' support } \\
\text { functions }\end{array}$ \\
\hline & & & & $\begin{array}{l}\text { Professionalisation and } \\
\text { capacity-strengthening functions }\end{array}$ \\
\hline & & & & $\begin{array}{l}\text { Business development and } \\
\text { co-ordination }\end{array}$ \\
\hline & & & & Central purchasing function \\
\hline & $\begin{array}{l}\text { Council of } \\
\text { Ministers }\end{array}$ & & & Drafting primary legislation \\
\hline
\end{tabular}




\begin{tabular}{|c|c|c|c|c|}
\hline \multirow{8}{*}{$\begin{array}{l}\text { 12. Latvia } \\
\text { (Centralised } \\
\text { structure) }\end{array}$} & \multirow{6}{*}{$\begin{array}{l}\text { Procurement } \\
\text { Monitoring } \\
\text { Bureau }\end{array}$} & \multirow[t]{6}{*}{32} & \multirow[t]{6}{*}{ Ministry of Finance } & $\begin{array}{l}\text { Advisory and operations' support } \\
\text { functions }\end{array}$ \\
\hline & & & & International co-ordination function \\
\hline & & & & Monitoring and control functions \\
\hline & & & & $\begin{array}{l}\text { Publication and information } \\
\text { functions }\end{array}$ \\
\hline & & & & $\begin{array}{l}\text { Professionalisation and } \\
\text { capacity-strengthening functions }\end{array}$ \\
\hline & & & & Complaints review and remedies \\
\hline & \multirow[t]{2}{*}{$\begin{array}{l}\text { Ministry of } \\
\text { Finance }\end{array}$} & \multirow[t]{2}{*}{3} & & $\begin{array}{l}\text { Drafting primary and secondary } \\
\text { legislation }\end{array}$ \\
\hline & & & & International co-ordination function \\
\hline \multirow{8}{*}{$\begin{array}{l}\text { 13. Lithuania } \\
\text { (Centralised } \\
\text { structure) }\end{array}$} & \multirow{6}{*}{$\begin{array}{l}\text { Public } \\
\text { Procurement } \\
\text { Office }\end{array}$} & \multirow[t]{6}{*}{60} & \multirow{6}{*}{$\begin{array}{l}\text { Office of the Prime } \\
\text { Minister }\end{array}$} & Drafting secondary legislation \\
\hline & & & & $\begin{array}{l}\text { Advisory and operations' support } \\
\text { functions }\end{array}$ \\
\hline & & & & International co-ordination function \\
\hline & & & & Monitoring and control functions \\
\hline & & & & $\begin{array}{l}\text { Publication and information } \\
\text { functions }\end{array}$ \\
\hline & & & & $\begin{array}{l}\text { Professionalisation and } \\
\text { capacity-strengthening functions }\end{array}$ \\
\hline & \multirow{2}{*}{$\begin{array}{l}\text { Ministry of } \\
\text { Economy }\end{array}$} & \multirow[t]{2}{*}{3} & & Drafting primary legislation \\
\hline & & & & International co-ordination function \\
\hline \multirow{5}{*}{$\begin{array}{l}\text { 14. Luxembourg } \\
\text { (Semi- centralised } \\
\text { structure) }\end{array}$} & \multirow{5}{*}{$\begin{array}{l}\text { Ministry of } \\
\text { Public Works }\end{array}$} & \multirow[t]{5}{*}{1} & & Drafting primary legislation \\
\hline & & & & Advisory functions \\
\hline & & & & International co-ordination function \\
\hline & & & & Monitoring functions \\
\hline & & & & Information functions \\
\hline \multirow{9}{*}{$\begin{array}{l}\text { 15. Malta } \\
\text { (Centralised } \\
\text { structure) }\end{array}$} & \multirow[t]{9}{*}{$\begin{array}{l}\text { Department of } \\
\text { Contracts }\end{array}$} & \multirow[t]{9}{*}{40} & \multirow[t]{9}{*}{ Ministry of Finance } & $\begin{array}{l}\text { Drafting primary and secondary } \\
\text { legislation }\end{array}$ \\
\hline & & & & $\begin{array}{l}\text { Advisory and operations' support } \\
\text { functions }\end{array}$ \\
\hline & & & & International co-ordination function \\
\hline & & & & Monitoring and control functions \\
\hline & & & & $\begin{array}{l}\text { Publication and information } \\
\text { functions }\end{array}$ \\
\hline & & & & $\begin{array}{l}\text { Professionalisation and } \\
\text { capacity-strengthening functions }\end{array}$ \\
\hline & & & & $\begin{array}{l}\text { Business development and } \\
\text { co-ordination }\end{array}$ \\
\hline & & & & Central purchasing function \\
\hline & & & & $\begin{array}{l}\text { Complaints review and remedies } \\
\text { (Appeals Board) }\end{array}$ \\
\hline
\end{tabular}




\begin{tabular}{|c|c|c|c|c|}
\hline \multirow{7}{*}{$\begin{array}{l}\text { 16. Poland } \\
\text { (Centralised } \\
\text { structure) }\end{array}$} & \multirow{7}{*}{$\begin{array}{l}\text { Public } \\
\text { Procurement } \\
\text { Office }\end{array}$} & \multirow[t]{7}{*}{116} & \multirow[t]{7}{*}{$\begin{array}{l}\text { Office of the Prime } \\
\text { Minister }\end{array}$} & $\begin{array}{l}\text { Drafting primary and secondary } \\
\text { legislation }\end{array}$ \\
\hline & & & & $\begin{array}{l}\text { Advisory and operations' support } \\
\text { functions }\end{array}$ \\
\hline & & & & International co-ordination function \\
\hline & & & & Monitoring and control functions \\
\hline & & & & $\begin{array}{l}\text { Publication and information } \\
\text { functions }\end{array}$ \\
\hline & & & & $\begin{array}{l}\text { Professionalisation and } \\
\text { capacity-strengthening functions }\end{array}$ \\
\hline & & & & $\begin{array}{l}\text { Complaints review and remedies } \\
\text { (Bureau of Appeals) - PPO } \\
\text { administers the system. }\end{array}$ \\
\hline \multirow{7}{*}{$\begin{array}{l}\text { 17. Portugal } \\
\text { (Decentralised } \\
\text { structure) }\end{array}$} & \multirow{5}{*}{$\begin{array}{l}\text { Directorate } \\
\text { General for } \\
\text { State } \\
\text { Property; } \\
\text { Directorate for } \\
\text { European } \\
\text { Affairs; }\end{array}$} & \multirow[t]{7}{*}{9} & \multirow[t]{7}{*}{ Council of Ministers } & $\begin{array}{l}\text { Policy functions and drafting } \\
\text { primary legislation (government) }\end{array}$ \\
\hline & & & & International co-ordination function \\
\hline & & & & Business co-ordination \\
\hline & & & & Central purchasing function \\
\hline & & & & Monitoring and control functions \\
\hline & $\begin{array}{l}\text { Department } \\
\text { for Public } \\
\text { Procurement; }\end{array}$ & & & Capacity-strengthening function \\
\hline & $\begin{array}{l}\text { Institute for } \\
\text { Public Works }\end{array}$ & & & \\
\hline \multirow{6}{*}{$\begin{array}{l}\text { 18. Romania } \\
\text { (Centralised } \\
\text { structure) }\end{array}$} & \multirow{6}{*}{$\begin{array}{l}\text { National } \\
\text { Authority for } \\
\text { Regulating } \\
\text { and Monitoring } \\
\text { Public } \\
\text { Procurement }\end{array}$} & \multirow[t]{6}{*}{70} & \multirow[t]{6}{*}{$\begin{array}{l}\text { Office of the Prime } \\
\text { Minister }\end{array}$} & $\begin{array}{l}\text { Drafting primary and secondary } \\
\text { legislation }\end{array}$ \\
\hline & & & & $\begin{array}{l}\text { Advisory and operations' support } \\
\text { functions }\end{array}$ \\
\hline & & & & International co-ordination function \\
\hline & & & & Monitoring and control functions \\
\hline & & & & Information functions \\
\hline & & & & $\begin{array}{l}\text { Professionalisation and } \\
\text { capacity-strengthening functions }\end{array}$ \\
\hline \multirow{7}{*}{$\begin{array}{l}\text { 19. Slovak } \\
\text { Republic } \\
\text { (Centralised } \\
\text { structure) }\end{array}$} & \multirow{7}{*}{$\begin{array}{l}\text { Office for } \\
\text { Public } \\
\text { Procurement }\end{array}$} & \multirow[t]{7}{*}{110} & \multirow[t]{7}{*}{ Council of Ministers } & $\begin{array}{l}\text { Drafting primary and secondary } \\
\text { legislation }\end{array}$ \\
\hline & & & & $\begin{array}{l}\text { Advisory and operations' support } \\
\text { functions }\end{array}$ \\
\hline & & & & International co-ordination function \\
\hline & & & & Monitoring and control functions \\
\hline & & & & $\begin{array}{l}\text { Publication and information } \\
\text { functions }\end{array}$ \\
\hline & & & & $\begin{array}{l}\text { Professionalisation and capacity- } \\
\text { strengthening functions }\end{array}$ \\
\hline & & & & Complaints review and remedies \\
\hline
\end{tabular}




\begin{tabular}{|c|c|c|c|c|}
\hline $\begin{array}{l}\text { 20. Slovenia } \\
\text { (Semi- centralised } \\
\text { structure) }\end{array}$ & $\begin{array}{l}\text { Department } \\
\text { for Public } \\
\text { Procurement, } \\
\text { Public Utilities } \\
\text { and } \\
\text { Concessions }\end{array}$ & 8 & Ministry of Finance & $\begin{array}{l}\text { Drafting primary and secondary } \\
\text { legislation } \\
\text { Advisory functions } \\
\text { International co-ordination function } \\
\text { Monitoring and control functions } \\
\text { Information functions }\end{array}$ \\
\hline $\begin{array}{l}\text { 21. Sweden } \\
\text { (Semi- centralised } \\
\text { structure) }\end{array}$ & $\begin{array}{l}\text { Board for } \\
\text { Public } \\
\text { Procurement }\end{array}$ & 10 & Ministry of Finance & $\begin{array}{l}\text { Advisory functions } \\
\text { International co-ordination function } \\
\text { (shared) } \\
\text { Monitoring functions } \\
\text { Information functions } \\
\text { Professionalisation and } \\
\text { capacity-strengthening functions }\end{array}$ \\
\hline & $\begin{array}{l}\text { Ministry of } \\
\text { Finance }\end{array}$ & 3 & & $\begin{array}{l}\text { Drafting primary and secondary } \\
\text { legislation } \\
\text { International co-ordination function }\end{array}$ \\
\hline $\begin{array}{l}\text { 22. United } \\
\text { Kingdom } \\
\text { (Semi- centralised } \\
\text { structure) }\end{array}$ & $\begin{array}{l}\text { Office of } \\
\text { Government } \\
\text { Commerce }\end{array}$ & $\begin{array}{c}25 \\
(500)\end{array}$ & $\begin{array}{l}\text { HM Treasury } \\
\text { (Ministry of } \\
\text { Finance) }\end{array}$ & $\begin{array}{l}\text { Drafting secondary legislation } \\
\text { Advisory and operations' support } \\
\text { functions } \\
\text { International co-ordination function } \\
\text { Monitoring functions } \\
\text { Information functions } \\
\text { Professionalisation and } \\
\text { capacity-strengthening functions } \\
\text { (shared) } \\
\text { Business development and } \\
\text { co-ordination (shared) }\end{array}$ \\
\hline
\end{tabular}


GOV/SIGMA(2007)4

\title{
APPENDIX INDIVIDUAL COUNTRY REPORTS OF EU MEMBER STATES
}

\author{
Central Public Procurement Structures and Capacity in EU Member States
}

\section{Austria}

Austria is found to have a semi-centralised public procurement structure, but still with one dominant institution at the federal level. It is the Bundeskanzleramt-Verfassungsdienst (BKA-VD), Referat für Vergaberecht (Federal Chancellor's Office-Constitutional Service, Section for Procurement Law), which has been attributed many of the relevant public procurement functions. However, central purchasing and related functions, such as advertising, are carried out by another organisation. Judicial review and control are also carried out by other institutions. Finally, research and training are carried out by the universities and various private providers.

BKA-VD's functions include drafting of primary and secondary legislation, developing a federal procurement policy, and preparing guidelines and instructions. It advises the federal government on public procurement policy and gives legal and other advice to contracting entities, utilities, and tenderers. However, this "help-desk function" is limited due to its small staff of four full-time civil servants with law degrees. The BKA-VD is the contact point for the Commission, the national contributor to EU advisory committees, UNCITRAL and the GPA. It participates in the PPN and other international networks. During the drafting of legislation written information is distributed to all interested stakeholders and published on the Internet. The consultation process is open to comments for everybody via the Internet. Representatives from the federal level and the states (Länder) of Austria meet regularly through the Bund-Länder Arbeitsgruppe (Federation-States Working Group) to discuss legislative issues concerning public procurement.

The Bundesvergabeamt (BVA, or Federal Procurement Review Authority) prepares an annual report to the government on the public procurement organisation regarding the remedies system at the federal level. One person at the Department for Multilateral Trade Policy at the Federal Ministry for Economy and Labour collects statistical and other data. There is neither a qualification list nor a permission system for less competitive procedures. A blacklist on illegal employment is kept by the Central Administrative Penal Evidence section of the Federal Ministry of Finance. The most important function of the BVA, however, is that of a review body for public procurement decisions at the federal level. BVA review decisions are subject to appeal to the Verwaltungsgerichtshof (administrative court).

The public company Bundesbeschaffung GmbH (BBG, Federal Procurement Limited) is a central purchasing agency for 18 federal ministries and 450 other entities (public companies, regional governments, municipalities, universities, health institutions) with an overall purchasing budget of 661 million euros (EUR) in 2005. It was established at federal level in 2001 by a federal law (BGBI I 39/2001 as amended by BGBI I 99/2002). It answers to the Ministry of Finance (MoF). The BBG is in charge of the procurement of all types of goods and services, from stationery to information technology, meals and facility management. It facilitates framework agreements but no concessions or PPPs. In 2004 the BBG set up an e-procurement procedure and is considering expanding it. The income of the BBG is part of the MoF budget and fees are charged for certain services. In 2005 the BBG budget was EUR 5 million. The BBG has 58 staff: 1 civil servant and 57 employees. They work as CEO (2 staff) or in the Purchasing Department (28 staff), the Legal Department (5 staff), the Controlling Department (2 staff), the Marketing Department (2 staff), the HR Department (1 staff), the Operation Management (3 staff), the Customer Competence Department (4 staff), and the e-Procurement Department (5 staff). The five people working in the Legal Department attended law college and have a university degree 
in law. In the Purchasing Department staff have either a technical or commercial background or another university degree.

In 2005, 5,000 notices were published in the national public procurement bulletin Lieferanzeiger. Under the Federal Public Procurement Law 2002 (BVergG) publication was obligatory at federal level. This is no longer the case under BVergG 2006. There are plans to make publication obligatory in the Amtlicher Lieferanzeiger (www.lieferanzeiger.at) once the Lieferanzeiger is registered as the e-sender of the Official Journal.

There is no official training programme. Private institutions cover training in cooperation with universities. The Zentrum für Verwaltungsmanagement (Centre for Administration Management) is developing a special training programme for public employees.

Due to the federal system there are $\mathbf{1 0}$ different review bodies: one at federal level and nine for the states. There are no fines for contracting authorities that violate public procurement rules. There is no dissolution of disputes between contracting entities and contractors in some of the states of Austria. The courts of auditors at federal and state level are in charge of auditing the public procurement activities of contracting entities.

Regional procurement institutions include state public procurement offices, public procurement units in state ministries, district procurement offices and municipal public procurement offices. Public procurement is an "inherent competence" of all local authorities. Therefore procurement functions exist at all level of state activities and are carried out by civil servants. The authorities at the regional and municipal level are entitled to establish central purchasing bodies according to BVergG 2006. Procuring entities at federal level other than the BBG, and at state level, have staff without a specific background. In municipal procuring entities, employees have a technical background and normally no degree.

\section{Bulgaria}

Bulgaria is found to have a centralised public procurement structure with one key institution at the central level, the Public Procurement Agency (PPA), which is a dependent part of the Ministry of Economy and Energy. It is an executive agency that was established by the Public Procurement Law (PPL) in 2004.

The PPA's functions include advising the government on public procurement policy development; drafting and commenting on primary and secondary legislation, including drafts for international agreements; developing standard procedures and routines; drafting standard notices and contract forms for public procurement contracts; and preparing guidelines and instructions. It issues the Public Procurement Handbook which consists of 1,131 legal guidelines on public procurement. There is an established telephone hotline giving legal and technical advice. The Minister of Economy and Energy is assisted by the PPA to implement the national policy for public procurement. The PPA is the contact point for the Commission and the national contributor to the EU advisory committees; it participates in the PPN. It produces an annual report for the government on the functioning of the public procurement system, based on its public procurement database (statistical and other data). The annual report is submitted for adoption by the Council of Ministers and published on the PPA website. All contract notices are published on the PPA website and the Internet site of the State Gazette after the PPA has checked their compliance with the requirements of the PPL. No paper version is maintained. In $2005,24,700$ notices within 8,396 public procurement procedures were published. Electronic procurement and e-notification are now available and require the use of a digital signature. The PPA publishes and distributes information on legislation and policy. In 2005, it published one practically oriented paper handbook, plus 12 methodological guidelines, four practical guidelines and five judicial practices on the PPA website. It maintains a Public Procurement Register, which publishes such information as the decisions for opening a procedure for awarding a public 
contract, the notices intended for publication, information on awarded public contracts and other information defined by the Rules on the Implementation of the Law. The electronic version of the standard notices is published in the State Gazette as well. The PPA organises a national training programme for the public and utilities sectors and tenderers. In 2005 PPA experts took part in 23 seminars. They were organised by other institutions to explain the implementation of public procurement legislation. PPA experts participated in 48 specialised national and five international seminars. The PPA does not administer a qualification list, a blacklist or a list of certified procurement officers. Permissions leading to less competitive procedures are not envisaged in the PPL but there is an obligation to explain the motivation for the type of special procedure chosen. On the PPA website there is a list of individuals whom contracting authorities may recruit as outside experts. This list is compiled with the assistance of professional associations and organisations.

The PPA is managed by an Executive Director, whose contract is signed, amended and terminated by the Minister of Economy and Energy in co-ordination with the Prime Minister. The PPA Executive Director appoints the Secretary General who directs, co-ordinates and controls PPA functioning according to secondary legislation and the requirements set by the Executive Director. The total number of PPA staff is 38, both civil servants and employees (although the number increased to 53 in March 2006). Thirty-four staff members have a Masters degree (19 in economics, 9 in law and 6 in IT). The PPA is divided into three main sub-divisions: the Financial and Legal Directorate (10 staff); the Monitoring. Analyses and Methodology Section (12 staff); and the Electronic Data Base (13 staff). In 2005, the PPA budget was EUR 286,000. The budget is drafted internally and then submitted to the Ministry of Economy and Energy for approval.

The amended PPL, which entered into force in July 2006, created the Commission for the Protection of Competition and a Court of Arbitration, which hear and settle public procurement disputes. Until July 2006 the PPA Executive Director could launch a court appeal against a contracting authority decision which violated the provisions of the PPL, as well as to annul contracts violating the law. However, the present PPL is enforced by the National Audit Office and the Public Internal Financial Control Agency.

To draft legislation, the Ministry of Economy and Energy sets up an internal working group with legal experts. After they have elaborated a legal draft, a co-ordination process starts among all institutions or organisations. Their comments may then lead to amendments of the draft.

The fact that the PPA functions as a public procurement headquarters is considered the main strength of the Bulgarian central procurement organisation. The agency is working constantly to develop and improve its administrative capacity.

\section{Cyprus}

Cyprus is found to have a centralised public procurement structure with one key institution at the central level, in particular in terms of policy and legislation, EU and international contacts, and control and monitoring. Practically all of these functions are carried out by the Public Procurement Directorate (PPD).

The PPD is a directorate within the Treasury of the Republic. The Treasury is independent of any ministry, and is headed by the Accountant General, who is appointed by the President and cannot be removed from office until retirement. The Treasury is directly under the supervision of the Minister of Finance, but does not form part of the Ministry of Finance. The PPD as a whole advises the government on issues of public procurement. It also issues guidelines in the form of circulars (four were issued in 2005). The Policy and Development Unit (PDU) of the PPD is responsible for drafting primary and secondary legislation, standard tender documents, standard contract documents and for developing general guidelines for the procurement policies to be developed by each contracting authority. It serves as a contact point for the Commission, 
ensures the national contribution to the EU advisory committees, PPN participation, and other international representation. The PDU is currently structuring and facilitating the introduction of e-procurement as well as framework agreements in Cyprus. It is also in charge of organising a national training programme for the public and utilities sectors. In 2005 two general courses were organised, attended by 300 people. The PDU has also represented Cyprus at EU level conferences. The Monitoring and Control Unit (MCU) of the PPD is in charge of preparing guidelines and instructions, assisting and monitoring contracting authorities, and collecting statistical and other data. The MCU also monitors the correct application of the Cypriot public procurement law. It consults contracting authorities when requested, such as when they face difficulties deciding on the form of the competition to procure (for example, exceptions from the law, extensions of deadlines, the use of accelerated procedures, etc). The helpdesk function is carried out by the MCU, which provides first level support to contracting authorities in explaining the public procurement legislation. Ex ante control of public procurement contracts is exercised for all EU-funded contracts, but there is no such control for contracts financed by Cypriot funds. The PPD is headed by the Deputy Accountant General, who is a professional accountant. It employs 14 people, excluding clerical staff.

A blacklist is administered by the Secretary of the Central Committee for Variations and Claims. Two companies were on this list in 2005. Central purchasing is carried out for the 79 contracting authorities at the central government level, mainly by the Department of Information Technology Services, the Public Works Department, the Electromechanical Services Department, and the Department of Government Purchasing and Supplies. A rough approximation of this central purchasing market is EUR 200 million, or $25 \%$ of the Cypriot procurement market. Cyprus used to have a central purchasing board located in the Treasury of the Republic but this was abolished by the new law transposing the EU Directives. The current trend is to decentralise decision-making and the awarding of contracts to allow each contracting authority to use its experience in the specific fields of interest. This enhances the republic's purchasing capacity and accelerates the procedure, thereby increasing the flexibility of the public sector. Two years after decentralising public procurement the benefits of centralising some functions that require specific skills and specialisation will be examined. Contracting authorities communicate their notices for contracts above the thresholds to the OJ themselves, about 300 in 2005. Contracts below thresholds are not published in the OJ, but are published in the Official Gazette of the Republic for amounts exceeding EUR 80,000 and below that amount if the simplified procedures are not used by the contracting authorities. The Law Office of the Republic provides legal and other advice for contracting entities, utilities and tenderers.

The public procurement review body in the sense of Article 2 (8) Directive 89/665/EEC is the Tenders Review Authority.

\section{Czech Republic}

The Czech Republic is found to have a centralised public procurement structure dominated by two institutions: the Ministry for Regional Development and the Office for the Protection of Competition. There are no plans to change this basic structure.

The Ministry for Regional Development, which is wholly a government body, is responsible for drafting primary and secondary legislation and implementing regulations. Part of the legislative process involves consultation, whereby a draft of the new law is sent to stakeholders for written comments. The ministry advises the government on public procurement policy and is in charge of collecting statistical and other data. It keeps a list of qualified suppliers on which 807 companies were registered during 2005. There is also a national qualification and classification system of contractors in the field of work contracts. The ministry prepares one comprehensive guide and administers a list of qualified procurement trainers who have been examined by the ministry. It also administers the information system for awarding public contracts; 7,242 contracts were 
published in 2005. The 1,600 Czech notices published in the OJ in 2005 were communicated by the contracting entities themselves. In 2005 the ministry facilitated about four concessions.

The Office for the Protection of Competition is responsible for preparing an annual report to government on the functioning of the public procurement system (see www.compet.cz, for the 2005 English version). It is also the public procurement review body in the sense of Article 2 (8) Directive 89/665/EEC. About 170 contracts have been subject to ex ante control by this office, 64 contracting authorities have been fined, and the office has helped resolve disputes between contracting authorities and tenderers in 539 cases. Of the 105 challenges filed with the office, 10 were appealed against at the Supreme Administrative Court. The office's legal foundation is based on:

- $\quad$ The Constitution;

- $\quad$ Act of Parliament no 2/1969 of the Collection of Laws, which is a general act about the constitution of ministries and other central administrative organs;

- $\quad$ Act no 273/1996 Coll. (governing the competency of the Office for Protection of Competition, especially in the field of public procurement);

- $\quad$ Act no 40/2004 Coll. (from 1 July 2006 the Act no 137/2006 on Public Contracts and the Act no 139/2006 on Concessions), which governs the supervision of the Office for the Protection of Competition.

The office is an independent body controlled by parliament. It is headed by a chairman who is appointed by the president on the suggestion of the government for a six-year term. He cannot be a member of any political party. The office is divided into three sections: Anti-trust, Public Procurement and State Aid. The public procurement section is headed by a director, who takes decisions in the first instance. The directors of sections are appointed by the chairman. In the second instance an appellate commission (appeals board), consisting of office employees and external specialists, takes decisions which are signed by the chairman. The legal department has a staff of six, the public procurement section has about 30 employees, the appellate commission has about 6 employees and about 20 external specialists, the organisation and finance department for the whole office has about 10 employees, and the office's department of European integration and international relations has about 10 employees. Most employees are university educated (law or economics). They also participate in seminars run by the office or the ministry, or in special seminars offered by other institutions (e.g. private education agencies, etc.), in twinning projects, international meetings and conferences. The chairman of the office or an official of the European integration and international department represents the Czech Republic on EU advisory committees, the PPN, and other international conferences. The office is funded from the government budget. According to Act no 40/2004 Coll., anyone filing a proposal had to pay a deposit of $1 \%$ of the tender price, as well as an administrative charge of about EUR 1,000. However, this administrative charge was removed by Act 137/2006, which entered into force on 1 July 2006. If the supervisory body ascertains, following conclusion of an agreement, that a contracting entity, by an action taken in the course of the award of a public contract, has failed to fulfil an obligation or has breached a ban set out by the above Act, and if such an action substantially affects or could affect the establishment of the rank-order of tenders' rating, then the supervisory body is entitled, subject to a written ruling in joint proceedings, to impose a ban on the performance of the agreement and to inflict a penalty on the contracting entity. The amount of the fine depends on the violation but can be up to $5 \%$ of the contract value, to a maximum of CZK 10 million (about EUR 333,333).

A number of functions are carried out by both the ministry and the office. These include preparing guidelines and instructions, answering questions from contracting authorities and organising 
courses on public procurement. In 2005 two courses were run by the office (about 120 participants in each) and about five courses by the ministry (80-100 participants in each). Both bodies participate in national and international academic international conferences, international seminars, national seminars and twinning projects.

There is currently no central purchasing body, but one should be established from July 12006.

\section{Estonia}

Estonia is found to have a centralised public procurement structure largely dominated by two organisations: the Public Procurement Office (PPO) and the Ministry of Finance. The PPO is a subsidiary of the ministry.

The Ministry of Finance is responsible for drafting primary and secondary legislation; preparing guidelines and instructions; acting as the contact point for the Commission; taking charge of the national contribution to EU advisory committees, the PPN and other international representation; and preparing guidelines. In 2005 it prepared a single universal book of guidelines. Legislation drafting includes consultation via special working groups formed of representatives of different stakeholders. The responsibilities of the ministry are stipulated in the Government of the Republic Act. The State Aid and Public Procurement Unit of the Public Governance Department of the Ministry of Finance (four civil servants dealing specifically with procurement) is responsible for legislation and policy, the EU and international contact function, and capacity development.

The Public Procurement Office (PPO) is responsible for preparing an annual report to the government on the functioning of the public procurement system; collecting statistical and other data; granting permission for less competitive procedures; using exceptions, extensions and accelerated procedures, etc.; and administering the national public procurement bulletin, including publication and checking that adverts fulfil requirements. This bulletin published 7,539 contracts in 2005. The PPO also takes care of communicating notices of contracting entities and utilities to the OJ. Approximately 300 notices were communicated to the OJ in 2005 . The PPO provides legal and other advice for contracting entities and utilities, whereas legal and other advice for tenderers is provided by law and consultancy firms. The ex ante control of public procurement contracts is another function; 10 contracts were subject to ex ante control in 2005. The PPO may also fine contracting authorities that violate public procurement rules; 18 cases were considered and 12 entities fined in 2005. The PPO assisted in the dissolution of 281 disputes between contracting entities and contractors in 2005. The ex post control of contracting entities regarding their public procurement activities is also a PPO function; 78 contracting authorities were reviewed in 2005.

The PPO's responsibilities are regulated under the Public Procurement Act and the Statute of the PPO, which is a decree of the Ministry of Finance. The PPO is independent in its decisions but it is a subsidiary of the Ministry of Finance and therefore partly dependent on it in some administrative respects. The Director General of the Public Procurement Office signs the decisions on protests and organises the work of the office. He or she is appointed by the Minister of Finance. The Department of Supervision (11 staff) performs the enforcement and remedies function, as well as control and monitoring. The Registry Department ( 7 staff) is in charge of publications and information. PPO staff consist of civil servants with a university degree, with the exception of the secretarial staff. They are all familiar with public procurement law. The PPO's annual budget is approximately EEK 7.5 million (EUR 0.5 million). It is part of the general state budget. Having a central supervisory, review, monitoring, and information body concentrating information and experience is seen as the main strength of the Estonian central procurement organisation. 
Some tasks are joint responsibilities of the Ministry of Finance and the PPO. These include developing a national procurement policy, publishing and distributing information on legislation and policy, advising the government on public procurement policy, and organising a national training programme for the public and utilities sectors and tenderers.

Bringing proceedings for judicial review in courts of law against violations of public procurement law is a task of both the PPO and the Prosecutor's Office. However, the latter is exclusively responsible for prosecuting corruption cases and other criminal offences in public procurement cases. The national contribution to UNCITRAL and GPA is the joint responsibility of the Ministry of Finance and the Ministry of Foreign Affairs. The Ministry of Economy and Communication administers a qualification list. In 2005 there was one such list containing approximately 20 registered companies.

Public procurement review bodies, in the sense of Article 2 (8) Directive 89/665/EEC, are the PPO and the courts of law in the last instance. There is a plan to separate the review function from the PPO by appointing a special review body which would only share the technical support staff with the PPO.

There is no central purchasing body in Estonia.

\section{Finland}

Finland is found to have a decentralised public procurement structure involving many different players. The Ministry of Finance and the Ministry of Trade and Industry (Trade Department) are the main administrative operators for most national public procurement issues. The Finnish public procurement market size is about $15 \%$ of GDP (some EUR 22 billion).

The Budget Department of the Ministry of Finance has overall steering responsibility, which includes developing and issuing procurement policies. Drafting standard contract documents is also the responsibility of this ministry (previously this was done by the Ministry of Trade and Industry). Steering also involves developing procurement processes and routines, such as central procurement and purchasing with its related primary and secondary legislation. Developing public procurement procedures and routines is part of the State Government's Productivity Programme, which was started by the Council of the State in late 2003 (the Ministry of Finance co-ordinates and leads this programme). The objective of this programme is an overall increase in the productivity of the Finnish State Government. The Ministry of Finance has delegated some important development duties to the State Treasury, especially for financial and personal administration. Within the Ministry of Finance, steering and development are the responsibility of both the Budget Department (one or two people) and the Public Management Department (two or three people). The Ministry of Finance issues general procurement guidelines/model documents and general terms of contracts for the government.

Primary and secondary legislation, as well as standard tender documents, are drafted by the Trade Department of the Ministry of Trade and Industry, which is also responsible for the national contributions to EU advisory committees, to UNCITRAL and the GPA. Statistical and other data are collected by three or four civil servants working in the Trade Department/Internal Market Division of this ministry. Both ministries participate in the PPN. In 2005/2006 the Ministry of Trade and Industry developed, together with Edita PIc, a new Internet procurement notification service (www.hankintailmoitukset.fi) for procurements below and over the EU threshold. Its first applications were launched in the first part of 2006, but some features are still under development. Some large offices (for example the Finnish Defense Forces) are using e-procurement, which is tailored to their needs. (Note: central e-procurement in Finland tendering and ordering - is being considered, but decisions for using these systems widely have not been made). 
The Ministry of Foreign Affairs is the contact point for the Commission. The other ministries and large state offices/agencies (such as the Ministry of Defence and the Finnish Defence Forces, the Ministry of Interior, the Finnish Road Authority) develop and implement their own procurement policies, procedures and routines for procuring their own goods, services or works.

The Governmental Board of Procurement, appointed by the Ministry of Finance, is in charge of several public procurement development projects (procedures, standard documents and e-procurement). It also issued the Governmental Procurement Strategy 2004. This board is composed of members from several ministries and some state offices. The ministries are responsible for seeing that this strategy is taken into account in their own procurement strategies and implemented in their field of administration. A few general guidelines (such as a general procurement manual) are prepared by the Ministry of Finance and the Governmental Board of Procurement, but in most case preparing procurement guidelines and instructions is the responsibility of the ministry or office/agency in question.

The Public Procurement Advisory Unit is an independent joint project of the Ministry of Trade and Industry and the Association of Finnish Local and Regional Authorities. It started operations in 2004 and serves both municipal and state authorities, other public procurement units, enterprises and entrepreneurs. It gives them free advice on public procurement law, the application of the law, good practices in procurement and the significance of strategic leadership for the provision and acquisition of services.

Commercial training organisations, most notably the government-controlled HAUS Ltd. (60\% owned by the state), offer a selection of training courses to the public, to utilities sectors and to tenderers. HAUS Ltd. (www.haus.fi) is subordinated to the Ministry of Finance and widely used by the public sector. For example, in 2005 HAUS Ltd. organised some 20 training courses (mostly lasting one or two days) in public procurement. The Finnish municipalities have a similar training company called Efeko Ltd., www.efeko.fi.

Policy-related projects of wider general significance are prepared in committees involving representatives from the various parts of government, political parties and other interest groups. These interest groups are also invited to comment on draft legislation.

Because of the independent nature of its municipalities, Finland's public procurement structure is genuinely decentralised. The local public procurement market is worth some EUR 10 billion annually. The Association of Finnish Local and Regional Authorities works closely with its municipalities on many important public procurement issues. For example, it provides a help desk service for legal issues and has published several public procurement manuals/guidelines and policy papers for municipalities.

The public procurement review body, in the sense of Article 2 (8) Directive 89/665/EEC, is the Market Court. In 2005 there were approximately 250 cases related to public procurement handled by the Market Court. In $10 \%$ of the cases the court considered awarding a compensation payment and it was awarded in some 5\% (about 15) of cases. The Market Court heard 508 complaints against public procurement decisions

Public procurement activities are audited annually as part of the financial audits and value-for-money audits conducted by the State Audit Office. In 2005 the State Audit Office conducted 115 financial audits and 25 value-for-money audits. In the financial audit, public procurement activities of the contracting entity were audited in approximately $30 \%$ of the audits conducted. Some 10 value-for-money audit reports reviewed the public procurement activities of particular contracting entities. The Ministry of Trade and Industry and the State Audit Office prepare an annual report to the government on the functioning of the public procurement system. 
The State of Finland has a Central Procurement Unit (Hansel Ltd., see www.hansel.fi). Hansel is a state-owned non-profit company and acts as a central purchasing body, establishing framework arrangements for the procurement of products and services. These framework agreements can be used by the public procurement authorities, such as ministries and ministerial offices, as well as state agencies and publicly owned enterprises. Hansel also administers those framework agreements it has concluded and markets them to its public sector clients. Currently Hansel Ltd. employs some 50 people. It operates wholly as a state government central procurement unit - it does not procure for the municipalities. Hansel is part of the administrative branch under the Ministry of Finance. It provides services to 13 ministries, 117 state account offices (with some 1,000 contracting departments/units), 10-20 agencies and state-owned companies. In 2005 public procurement carried out through Hansel's central procurement (frameworks) was worth EUR 211 million (in 2004 it was EUR 154 million). Hansel Ltd. operated 53 frameworks in 2005. Some ministries operate separate frameworks.

One or two PPPs were facilitated by the Ministry of Transport and Communications. In Finland the PPPs have only been used (at least in the state government) for exceptionally large road construction projects.

\section{France}

France is found to have a semi-centralised public procurement structure, but with a key institution at the central level, the Public Procurement Department of the Directorate for Legal Affairs (DAJ: Direction des Affaires Juridiques). This directorate comes under the Ministry of Economy, Finance and Industry. Some functions are carried out by other institutions, most notably the judicial review and central purchasing functions.

The Public Procurement Department is responsible for drafting primary and secondary legislation, standard tender documents (limited), and standard contract documents (limited). It is also in charge of developing procurement policy, and preparing guidelines and instructions. Other ministries or institutions can draft documents for their own use or for contracts of any entities which come within the scope of their activities. For instance, the Ministry of Culture issued a model contract for architectural services. In terms of consultation, usually the DAJ prepares a first draft of a decree, which is sent to the other administrations involved in procurement (Ministries of Interior, Defence, Health, Public Works), and also puts it on the website for public consultation. Then it prepares an amended draft, taking into account (where possible) comments received. After being adopted by the government, this draft is sent to the Conseil d'Etat, which can propose amendments. The government is not bound by the opinion of the Conseil d'Etat, but it does usually take its opinion into account. The DAJ is the contact point for the Commission, organises the national contribution to EU advisory committees, UNCITRAL, and the GPA and participates in the PPN. Advising the government on public procurement policy is another task of the DAJ, and it also provides legal and other advice to contracting authorities and utilities. A specialised "information cell" connected to the Directorate for Public Accounting (within the Ministry of Economy, Finance and Industry) provides advice and information to any other entities. One strength of the French central procurement system is that any public officer in charge of drafting or awarding a public contract can easily obtain advice or information about the public procurement legislation from the DAJ or the information cell. The DAJ does not organise training and research activities on a permanent basis, but can organise seminars if the code for public procurement has been modified.

The DAJ was set up in 1998 by a decree of the Prime Minister. In accordance with the Constitution, the rules to be applied by the state administrations can be enacted by a decree. The government is empowered by a "décret-loi" to oblige (without having to ask the parliament to adopt an act) local authorities to apply the same rules and procedures as the state. The director of the DAJ is appointed by a decree and he reports to the minister. The DAJ includes four 
sub-directorates: public procurement, private law, public and international law, economic law and development. Only the first sub-directorate works on public procurement issues and includes three units: general legislation and international issues, advice to public purchasers, and prospective and technical issues. Its annual budget is about EUR 3.6 million and is part of the general governmental or ministerial budget. From 2006 the budget will be determined on the basis of a programme of objectives. The State Public Contract Commission is also connected to the DAJ. About 40 people work for the public procurement directorate and 18 for the State Commission. Thirty civil servants in the DAJ procurement sub-directorate have a university degree.

A public procurement watchdog (Observatoire économique des marchés publics) was set up in November 2005. It will work in close collaboration with the DAJ. The mission to support PPP contracts (Mission d'appui aux contrats de partenariat public-privé) was set up in 2004. By the end of 2005, 40 projects were under examination. Contract notices can be sent to the OJ by the contracting entities either directly, or through the Bulletin officiel des Annonces de marchés publics. In 2004, 38,921 calls for tender were published in the OJ. Several public or private entities organise courses on the public procurement legislation or more practical aspects. Municipalities and more generally any bodies governed by public law can group together in order to award contracts or framework agreements.

France has only one central purchasing body (UGAP: Union des Groupements d'achat publics), which can provide any public authorities with goods. In addition, there are several hundred local groupings which carry out similar activities. The 2004 turnover of UGAP was EUR 668 million, and it had 33,000 customers including 8,500 municipalities (of less than 5000 inhabitants) and 6,300 secondary schools.

Public procurement decisions are reviewed through the court system.

\section{Germany}

Germany is found to have a semi-centralised public procurement structure, but with one key procurement institution at the federal level, which is the Federal Ministry of Economy and Technology (Bundesministerium für Wirtschaft und Technologie or BMWi). It co-operates with other bodies for certain functions.

The BMWi drafts primary legislation and develops a federal procurement policy. It is also the contact point for the Commission and responsible for the national contribution to EU advisory committees and PPN participation, the national contribution to UNCITRAL, to the GPA, and for other international representation. It also publishes and distributes information on legislation and policy; advises the federal government on public procurement policy; and collects statistical and other data, especially for review procedures.

The drafting of secondary legislation is conducted by the BMWi in cooperation with the Public Procurement Committees (Verdingungsausschüsse), which are composed of representatives of federal - and federal state ministries as well as municipalities - and business organisations. The purpose of this uniquely German procedure, practised since the 1930s, is to take the opinion of the various stakeholders into account and to achieve a balance between the public interest and the interests of the private sector. However, some argue that it favours private sector interests to the detriment of the public interest. The consultation process in general is organised as a written procedure, complemented, if necessary, by hearings. The process opens with the transmission of the draft to the federal states, the municipal and the business organisations. This gives them the opportunity to return a written statement. For reasons of clarification a hearing may be arranged. 
Standard procedures and routines are developed by the BMWi in cooperation with the Federal Ministry of Transport, Building and Urban Affairs (Bundesministerium für Verkehr, Bau und Stadtentwicklung or BMVBS); the Federal Government Co-ordination and Advisory Agency (Koordinierungs und Beratungsstelle der Bundesregierung für Informationstechnik in der Bundesverwaltung); and the Procurement Office of the Federal Ministry of the Interior (Beschaffungsamt des Bundesministerium des Innern, or BeschA). The drafting of standard tender documents and standard contract documents is the task of the BMWi, BMVBS, KBSt and BeschA, while guidelines and instructions are prepared by BMWi, BMVBS and BeschA. Legal and other advice for contracting entities, utilities and tenderers is provided by the BMWi; the ministries of the federal states; and the joint tender-advice-agencies (Auftragsberatungsstellen) of the Chambers of Industry and Commerce and the Chambers of Crafts. Representatives of the BMWi and the Federal Ministry of the Interior (Bundesministerium des Innern, or BMI), including the subordinated offices, attend national and international academic and other events on public procurement law, economics and policy.

Each contracting entity decides on the use of less competitive procedures, the use of exceptions, extensions, or the use of the accelerated procedures, etc. However, there is state supervision, through the respective superior administrative level, of the legality or appropriateness of administrative acts.

Qualification lists are administered for works contracts by the Verein für die Präqualifikation von Bauunternehmen, an association of contracting entities, tenderers and business organisations for the prequalification of building companies. At the present time there are 33 companies on the list which was started in 2006.

Federal blacklist legislation is under consideration. It exists at the state level in the federal state of Northrine-Westphalia and there are blacklists on sub-legal basis (guidelines) in various federal ministries and at state level.

At the federal level central purchasing is conducted by the BeschA; the Federal Office for Military Technology and Procurement (Bundesamt für Wehrtechnik und Beschaffung); and the Procurement Office of the Federal Customs Administration (Beschaffungsamt der Bundeszollverwaltung). At sub-national level there are several forms of central purchasing.

The Bundesverwaltungsamt administers the national electronic public procurement bulletin (www.bund.de), which published 4,285 contracts in 2005. There is also a wide range of additional national or sub-national publication possibilities for contracting entities. An example is the Deutsches Ausschreibungsblatt, formerly called "Bundesausschreibungsblat", which has published about 35,000 contracts.

The Federal Academy of Public Administration (Bundesakademie für öffentliche Verwaltung im Bundesministerium des Innern) organises training programmes for contracting authorities; there is also a wide range of training programmes at the state level.

Independent teaching and research at universities, training colleges and through private companies is facilitated by organisations like the Auftragsberatungsstellen (Procurement Advisory Offices). These offices are joint ventures of the public sector and the chambers of commerce, addressing the need to advise tenderers in times of tight public budgets. This partly privatised opportunity to seek advice is considered necessary because otherwise too many tenders risk disqualification. There is a wide range of specific research programmes.

The public procurement review bodies, in the sense of Article 2 (8) Directive 89/665/EEC, are the Procurement Chambers (Vergabekammern). The review of public procurement decisions is conducted by Procurement Scrutiny Units (Vergabeprüfstellen) according to $\S 103$ GWB (Anti-Cartel Law). They offer an alternative and non-obligatory review path, which is, however, 
not used very often in practice. The public prosecution authorities (Staatsanwaltschaften) are in charge of prosecuting cases of corruption and other criminal offences in public procurement cases. Judicial review of public procurement decisions is carried out by about 20 high courts (Oberlandesgerichte). Of 1,348 decisions made by the Vergabekammern, 286 were subject to judicial review by the high courts.

There are no plans to change the decentralised structure of the German procurement system. The central procurement of standardised supplies and services may be enlarged within e-procurement projects relating to framework agreements.

\section{Hungary}

Hungary is found to have a centralised public procurement structure with the most dominant institution being the Public Procurement Council (PPC), established in 1995. The current structure is considered adequate to cope with the tasks at hand and no major changes are planned for the near future.

The Public Procurement Council was established by the 1995 Act on Public Procurement (APP). Its current legal foundation is the 2003 APP. The PPC is an autonomous administrative body subordinated only to parliament, according to Article 374 (1). Its members are appointed by representatives of the three stakeholders in equal proportions: tenderers, contracting entities and people representing public interests. The act defines the organisations/people entitled to appoint members. Members elect a president for a five-year term of office with a two-thirds majority, and a vice-president for two years with a simple majority. The council budget is allocated separately in the annual budget with prior approval of parliament. The members of the PPC, with the exception of the president, are not employed full-time. The council must be in session at least six times a year and its working body, the PPC, issues recommendations to clarify recurring problems in applying public procurement law.

The president of the council issues briefings on practical issues. These documents are not legally binding and are published in the Public Procurement Bulletin and on the council's website. In 2005 the PPC published 21 briefings from the president and one recommendation. In 2005 it provided written legal advice in about 500 cases, and responded to an average of 50 telephone requests a day. Both contracting entities and tenderers may ask the PPC for advice. A list of approved contractors, in accordance with Article 52 of Directive 2004/18/EC, is also administered by the PPC. This list had 140 companies registered on it in 2005. The PPC participates in international activities (e.g. EC Advisory Committees- ACPC, EU Public Procurement Working Lab, and PPN) with the exception of the national contribution to international regulation (GPA, UNCITRAL). The PPC collects statistical and other data. It also administers a list of official public procurement consultants, conciliators and contracting entities $(8,241$ entries in 2005), along with a list of tenderers excluded from participating in award procedures through a final judgement by the review bodies. Currently this list is empty. The PPC is in charge of publishing notices in the Bulletin, which appear along with contract notices published by Hungarian contracting entities in the OJ. The PPC checks notices about procurement legislation requirements. About 25,000 such notices were published in 2005 . The council also communicates the tender notices of Hungarian contracting entities to the $\mathbf{O J}$ (991 in 2005). The PCC publishes important procurement legislative amendments in the Bulletin and on the PPC website, while the official text of the amendments is published in the Hungarian Official Gazette. According to the APP the PPC must report on its activities to parliament.

Regarding electronic procurement, the only electronic dispatch of notices is via the notice management system operated by the PPC. Other electronic operations have not been commissioned yet. Framework rules have only been developed so far for e-auction and dynamic procurement systems; the detailed rules are not yet in place. In 2005 about 6 to $8 \%$ of notices 
were dispatched electronically for publication by contracting entities or their representatives. With regards to public procurement above the EC thresholds, it has been mandatory since January 1 2005 to involve official public procurement consultants in at least the preparation and drafting of the tender notice and documentation. The PPC administers a list of about 500 official public procurement consultants; 357 were entered in 2005. The conditions for qualifying as a consultant (e.g. certified professional experience, assurance qualifications) are stated in the APP and two ministerial decrees. The PPC examines the fulfilment of the conditions.

In all cases the creation of legislation is preceded by a consultation process, involving, besides the ministries, representation bodies. According to the APP all drafts legislation concerning public procurement must be sent to the PPC for an opinion. In accordance with Article 3 of Directive 89/665/EEC on co-ordination of law, regulations and administrative provisions for the application of review procedures, the PPC is the contact point for the Commission. A conciliation procedure is initiated through, but not by, the PPC.

The working body of the PPC, the Secretariat, is supervised by the Secretary General and divided into various units. The Secretary General was appointed by the council in 1995 with an indefinite term of office. Article XXIII of the 1992 Act on the Legal Standing of Civil Servants governs when civil service positions must be filled through open competition and this is the case for the Secretariat staff. The Secretariat prepares and implements PPC decisions and fulfils tasks directly related to the above Act without direct instructions from the council. The Legal Unit (6 staff) is in charge of giving legal advice, preparing the draft recommendations of the council and the president's briefings, administering the list of conciliators and preparing contracts. The Unit of International Relations ( 3 staff) and Training ( 2 staff) has the following roles:

- It represents the PPC at international events.

- It responds to questions received from abroad.

- It participates in the work of the EU Advisory Committee (ACPC) and working groups, in PPN and in other initiatives.

- It contributes to public procurement training, helps set out professional and examination criteria, monitors the quality of the training and publishes information related to the training activities.

- It administers the list of official public procurement consultants and assesses petitions from consultants.

- It prepares briefings concerning training and international issues.

The Editorial Board (13 staff) is responsible for: publishing notices in the Bulletin and communicating notices related to community procedures to the $\mathrm{OJ}$; revising all notices from the point of view of public procurement legislation; returning notices for the supplementation of missing data; and operating the electronic notice management system and the PPC's Internet homepage. The Economic Analysis Group (2 staff) takes care of the management and analysis of public procurement statistics. The Financial Unit and Manager of Human Resources (9 staff) plans the PPC's budget, organises consultation with the Ministry of Finance, implements and controls the approved budgetary allocation and does the invoicing, payroll calculations and money transfers. The latter is in charge of administering the civil servant name-list, managing the declarations of wealth, administering position qualification and transfers, managing contests, and helping to select staff. Finally, the Internal Controller conducts financial audits within the organisation.

Most members of staff are civil servants but some are employed on a part-time basis under general or special assignment conditions. According to Hungarian law, civil servants must have a 
secondary school graduation diploma, and a medium level vocational diploma is required for administrative posts. A civil servant also has to pass a public administration professional examination (and lawyers must pass a legal professional examination) within three years of employment. Public procurement commissioners need a higher education diploma, three years' professional experience, and a legal or public administration professional examination. In 2005 there were 23 commissioners, and 33 of the Secretariat staff possessed higher education diplomas. There are 23 members of staff without higher education diplomas occupying clerical posts in the Secretariat and in the Arbitration Board.

In 2005 the PPC's budget was HUF 1,035.4 million (the equivalent of EUR 4,090,065). The budget is part of the annual budgetary act. The budget is prepared through consultations between the staff of the Secretariat and the Ministry of Finance and adopted by parliament. However, income is also derived from fees and fines (50\%). Fees which provide income to the PPC include publication fees, public administration service fees related to the administration of various lists (official public procurement consultants, approved contractors, conciliators), and fees for starting a review procedure. In addition, Bulletin sales also go to the PPC (although this income is substantially lower than publication costs). Government Decree 34/2004 sets down the rules for publication fees: HUF 8,000 (approx. EUR 28) for a national notice; HUF 4,000 + VAT per page (one page equals about 1,500 characters) for a community notice. The reason for the difference between the two fees is that in a Community procedure the contracting entity pays only for the control of the notice, as publication in the OJ is free. The APP defines the list administration fees, which is HUF 80,000 (approx. EUR 280), for figuring in the official name list of official public procurement consultants, and for figuring in the name list of conciliators. The official public procurement consultant can annually renew and certify activities performed in the past period for a fee of HUF 30,000 (approx. EUR 105). The fee for figuring in the list of approved contractors is HUF 150,000 (approx. EUR 525). The administration fee for requesting a legal remedy is HUF 150,000 (approx. EUR 525) or HUF 900,000 (approx. EUR 3,160), depending on the value of the contract and the object of the case. Besides these, $50 \%$ of the fines imposed by the Arbitration Board provide income for the PPC; the remainder goes into the central budget.

The Civil Law, Codification and International Private Law Department of the Ministry of Justice and Law Enforcement (MJLE) drafts primary legislation. This is done by a deputy head of department, directed by a secretary of state and supported by three legal advisors (civil servants). Plans and drafts of legislation are published by the body responsible for the respective field on their Internet homepage. When the draft legislation amends at least one-fifth of the provisions in an existing law, the drafter must publish the law to be amended on their homepage, including a time-limit for communicating comments. Anyone can express a view and make a proposal related to the published plans and drafts within at least 15 days. The drafter of the legislation must publish on their homepage an assessment and summary of the views and an explanation of why any views were rejected (except for apparently unfounded views). The drafter is not bound to provide individual responses. They then send the draft directly to the concerned organisations, who are given a time limit for comments. The drafter can also initiate oral consultations with the concerned organisations. The drafting and the preparation of secondary legislation is the task of the specific ministry, but in close co-operation with MJLE staff. The MJLE is also in charge of the national contribution to UNCITRAL.

Procurement policy is the responsibility of the MJLE, the PPC and other ministries. The national contribution to the EU advisory committees is organised by the MJLE, the PPC, and in the electronic working group of ACPC - besides the above mentioned - the Central Services Directorate, and the Electronic Governance Centre of the Prime Minister's Office. Both MJLE and PPC participate in the PPN. Concerning infringement procedures, according to Article 226 of the EC Treaty, the Ministry of Foreign Affairs (previously the Office for European Affairs) is the 
contact point for the Commission. The national contribution to GPA is the task of the Permanent Representation at the WTO.

The Committee of Parliament may allow the non-application of the APP when procurement is related to state secrets, service secrets and national security interests. The APP gives the chairman of the Public Procurement Arbitration Board (see below) the right to operate alongside the PPC to supervise negotiated and simplified procedures (for category II/B services) without prior publication. The chairman of the PPAB received information on 1,220 occasions about intentions to apply a negotiated or simplified procedure without the prior publication of a notice.

Central purchasing for other contracting entities is conducted through the Central Services Directorate (CSD). It is mandatory for about 1,000 institutions to procure certain goods and services through this directorate. In addition, other contracting entities may join the system voluntarily; 900 did so in 2005. About $12 \%$ of the Hungarian contracting entities used central purchasing in 2005 and the value of goods and services procured through the CSD was HUF 65 billion (EUR 257 million), about $5 \%$ of the total value of procurement in Hungary. Between May 1 2004 and January 152006 only the CSD could conclude a framework agreement within the scope of classical contracting authorities above the EC thresholds; below these thresholds any contracting entity could do so. Since May 12004 utilities could also use framework agreements for contracts above the thresholds. Since January 152006 all contacting entities can use this procedure.

Various training programmes are organised, mainly by the private sector, and supervised by specific organisations. PPC officers lecture on these courses, and chair the examination boards of the public procurement experts courses. The training of officials is implemented under the supervision of the PPC. In 2005 various training institutions organised about 80 public procurement expert courses (a state-recognised vocational training which lasts for a maximum of 220 hours.) In 2005, 1,339 people attended the public procurement expert courses. Public procurement is on the core curricula of universities and colleges (either as a part of a relevant field or as an independent subject). In addition to the public procurement expert courses, private institutions also organise other types of training courses. The PPC publishes information about training activities reported to them on their homepage. The PPC, MJLE and other ministries and public bodies participate in national and international academic and other events on public procurement law, economics, and policy. The PPC attended about 20 such events in 2005 . Apart from private training courses, there also are publications issued by private ventures, and it is possible to register on the Internet for the Public Procurement Newsletters (which are released by several private companies): weekly e-mail public procurement news for registered users.

The public procurement review body, in the sense of Article 2 (8) Directive 89/665/EEC, is the Public Procurement Arbitration Board (PPAB) which has the same structure as the PPC. This board (and the courts, when reviewing PPAB decisions) may impose fines according to the APP. The fine may not exceed $30 \%$ of the value of the contract in question. In practice, however, it never exceeds $5 \%$ of the procurement value, normally between EUR 3,500 and EUR 7,000. If the public procurement procedure was unjustifiably and maliciously ignored, the fine must not be less than EUR 7,000 and no more than $30 \%$ of the contract value, and in the case of a natural person approx. EUR 700. In 2005 the PPAB imposed fines in 321 cases (violations of law were stated in 452 cases). It may also impose an administration fee in the context of the review procedure. On the basis of Article 338 of the APP the board may impose a procedural fine of between HUF 50,000 and 500,000 (approximately EUR 198 and EUR 1,975)on the actor of the public procurement procedure, when a) they provide false data, or hide data that would be substantial in judging the case; b) do not provide information, or not in the time limit set down; c) they place obstacles in the way of access to documents related to economic, professional, or public 
procurement activity; d) they make an obviously unfounded statement regarding exclusion, or in the same procedure repeatedly make an unjustified statement against the same arbitration commissioner. The fine may be repeatedly imposed. In 2005 there were nine conciliation procedures.

The PPAB operates alongside the PPC. Arbitration commissioners are in their posts as full-time civil servants. The three-member panel adjudicating in the review procedures is appointed by the chairman of the arbitration board. In 2005 there were 79 people working in the PPAB and the Secretariat. PPAB staff is selected through a public contest; their employment is for an undetermined term. The arbitration commissioners are appointed and removed by the PPC. The chairman and deputy chairman of PPAB are elected from the arbitration commissioners by the PPC, on the basis of a contest, for a five-year term.

According to the law on criminal procedure, anyone who learns of an infringement can submit a complaint. According to the APP, when the PPAB suspects a crime has been committed, they must inform the relevant investigation agency. Responsible organisations for auditing contracting entities for their public procurement activities are the State Audit Office, Government Control Office, institutions providing EU funds and/or budgetary support and county central administration offices.

The Municipal Court is responsible for judicial review of public procurement decisions in the first instance; in the second instance it is the Municipal Court of Appeals. In 2005, 244 decisions were subject to judicial review.

10. Ireland

Ireland is found to have a semi-centralised public procurement structure, but with one key institution at the central level, the National Public Procurement Policy Unit (NPPPU), which forms part of the Department of Finance.

The NPPPU is in charge of drafting primary and secondary legislation, developing standard procedures and routines, drafting standard tender documents (when this is done centrally), drafting standard contract documents, developing procurement policy, and preparing guidelines and instructions. The stakeholders are involved in the legislative process through committees of public procurement personnel/procurement officers, the Government Contracts Committee, e-procurement networks, and a representative body, the Forum on Public Procurement in Ireland. The NPPPU is the contact point for the Commission, prepares the national contribution to EU Advisory Committees and participates in the PPN. The NPPPU is also in charge of collecting statistical and other data and preparing guidelines, two of which were compiled in 2005. In addition it administers a list of certified procurement officers, advises the government on public procurement policy, and provides legal and other advice to contracting entities and utilities (Office of the Attorney General for formal legal advice). The NPPPU is also sponsoring a third level postgraduate course in public procurement to commence in September 2006. The unit is financed through the general government budget passed by parliament. It currently has a staff of 11-12 members, comprising a head of unit, a construction professional adviser, five staff at mid-management level, and four or five clerical staff.

The national Health Service Executive has a Procurement Agency which carries out many of the NPPPU functions outlined above for the health sector. The Department of Enterprise, Trade and Employment is in charge of the national contribution to the GPA. This exists to a very limited extent, and the country's input is mainly reflected in its EU Commission contribution. The Institute of Public Administration (IPA) organises a national training programme for the public and utilities sectors. In 2005 this involved a 20-day course for 20 people, all of whom were examined. In the same year the Civil Service Training Unit organised four two-day courses for 60 people each. Private sector consultancies and law firms provide numerous short-term 
courses. The Department of Finance ICT Agency and the Local Government Computer Services Board facilitate some framework agreements: three in 2005. Moreover, there were some 20 projects (privately financed and over EUR $20 \mathrm{~m}$ ) being procured or under construction. Three e-procurement projects were supervised in 2005.

The Office of Public Works/Government Supplies Agency procures centrally for about 30 Departments and Offices, very roughly $3 \%$ of the overall market. A small amount of central purchasing is carried out in the eastern region by the Health Service Executive.

The High Court is a public procurement review body in the sense of Article 2 (8) Directive 89/665/EEC, reviewing about three or four cases every year.

Irish procurement structure has historically been mainly decentralised. However, since its establishment in 2002 the NPPPPU has been promoting a more strategic national approach to public procurement. This involves putting the function on a more professional footing, aggregating requirements where appropriate, and discussing the possible creation of a national operations unit. This might involve more aggregation and collaboration at national level. The strategy involves putting in place a structure that would facilitate appropriate use of electronic tendering and purchasing.

11. Italy

Italy is found to have a semi-centralised public procurement structure, but still dominated by two institutions: the Public Works Authority (PWA) and Consip (originally the abbreviation of Concessionaria Servizi Informatici Pubblici - see below). Important functions are also assigned to Parliament, the Council of Ministers, the Ministry of Infrastructure, the regions and self-governing provinces, the Antitrust Authority, the Department for Community Policies, the Italian Statistic Centre (ISTAT), and the Institute of Studies and Economic Research (ISAE). Moreover, the country has a vertically organised procurement structure in which regions, provinces and municipalities carry out local procurement.

The Public Works Authority (PWA) is an independent authority answering to Parliament. It was instituted by Law no. 109 of 11 February 1994 and established in January 1999. The PWA is a collegiate body, composed of five members who take decisions by majority vote. The law gives the PWA general oversight and control over public procurement procedures. Its aim is to assure timeliness, correctness and transparency in public administrations proceedings, as well as value for money of public procurement management. Another aim is to point out areas where efficiency and effectiveness can be improved. The new Law no. 62/2005 has added the surveillance of services, supplies and utilities contracts in compliance with Directive 18/2004/EC and Directive $17 / 2004 / E C$ to its functions. The PWA can require contracting authorities and private companies to provide data and information about procurement in progress and about public procurement contract awards. It also supervises tender qualification systems and is in charge of the arbitration of disputes (through the independent Arbitration Court).

According to Article 4 of Law 109/94, the PWA's main activities are:

a) supervising economic and financial proficiency in the execution of public procurement;

b) supervising compliance with primary and secondary rules through auditing and sample checks to ensure the correctness and soundness of award procedures;

c) auditing the occurrence of loss for the Treasury;

d) informing both parliament and government on particularly serious cases concerning compliance or misapplication of the relevant rules; 
e) sending to the public equipment administration suggestions for amending the regulations;

f) reporting annually to parliament and government on key irregularities, particularly concerning:

- resort to the non-competitive award of contracts

- insufficient advertisement

- frequency of procurement stoppages and variants

- breach of contracts towards operators and concessionaires

- abnormal increases in litigation

g) supervising the Observatory;

h) applying sanctions;

i) supervising qualitative selection.

The PWA Observatory administers a blacklist on which 2,993 tenderers were entered in 2005. The PWA can fine contracting authorities that violate public procurement rules: the highest possible fine is about EUR 50,000. To date 151 cases have been considered for such fines, and 36 contracting authorities were actually fined. The PWA also took disciplinary measures against 27 individual contracting officers during the same year.

The PWA has a chairman and four members appointed jointly by the Speakers of the Senate and the Chamber of Deputies. The chairman of the board is elected by the members themselves. Each member remains in office for a five-year non-renewable term. The PWA is divided into three main units: A) The Technical Secretariat supports the PWA in all its activities by preparing interpretative documents or regulations. B) The Inspection Service is the operational branch of the PWA; it conducts controls and makes inquiries in the area of public works. C) The Observatory electronically acquires data and information about public procurement. It also formulates standardised costs and provides statistics as well as cost-benefit analysis to support the PWA activity. It is organised in a central unit with regional branches, hence there is also a certain degree of vertical decentralisation. In 2006 the PWA had a staff of 237 civil servants, most of whom had a degree in engineering, law or economics. About $70 \%$ of staff is familiar with EC law. The PWA was financed by the general government budget, but only until the budgetary year 2005. Starting from 2006, the PWA will have to raise its funds from the contracting authorities, bids/tendering, and the qualitative selection certifying companies. Its 2005 budget was about EUR 20 million.

\section{CONSIP: TASK AND STRUCTURE}

Consip is a limited company, totally and directly owned by the Ministry of Economy and Finance (MEF). It operates only to serve two main branches of the public administration: ICT (Information Technology Division) and the PA Online Purchasing Division (DARPA).

Consip's main tasks are to:

- $\quad$ support the design of organisational processes of the Ministry of the Economy and Finances, using IT technologies (as a consequence of the 1997 Legislative Decree);

- $\quad$ support the public administration in the rationalisation programme of public spending on goods and services (as a consequence of two ministerial decrees of February 2000 and May 2001). 
Around $\mathbf{5 0 0}$ employees work in Consip, 355 of whom have a university degree. The board of directors is nominated by the Ministry of Economy and Finance and composed of nine members, including the Chairman and the CEO. Consip is divided into 10 units: Control and Finance, Legal and Corporate Affairs, HR \& Organisation, Corporate Identity, General Directorate, Operations, Research \& Special Project, Public Finance Directorate, Information Systems Directorate and the PA Online Purchasing Directorate.

Of particular interest was the founding of a Research Unit composed of economists in 2003. The main activities of this unit are to:

- $\quad$ analyse Consip's procurement strategies (ICT + DARPA);

- $\quad$ study innovative auction formats and contracts aimed at increasing the quality of products and services provided throughout the framework contracts;

- $\quad$ publish working papers (in particular, the most recent publication: the Handbook of Procurement edited by Cambridge University Press);

- $\quad$ organise seminars by internationally renowned professors specialised in public procurement and auction design (subjects have included: risk management in procurement, competition among electronic platforms, privacy economics and procurement, public procurement in Sweden, economic aspects and policy implications, scoring rules).

\section{Consip: The Rationalisation Programme}

This programme aims to rationalise public spending, and has two main objectives and targets:

1. The public administration: to establish a central purchasing agency to improve the efficiency of public procurement, reduce public expenditure, and provide consulting support for specific PA projects. The expected result is to guarantee a range of goods and services to the PA that maximises the trade-off between quality and cost;

2. The supply market: to make innovative e-procurement instruments available so as to reduce commercial costs by increasing access to a high potential market.

The programme's goals and strategies have three main levels:

1. Service efficiency and quality, with a focus on quality, ensuring a wide range of options within contracts and systematic service-level assessment;

2. Process simplification, through a shortened tendering process, close to zero time to market and online ordering;

3. Cost savings, via economies of scale through demand aggregation and purchasing standardisation, and competitiveness.

The intended outcomes are "transparency and timely tracking in PA expenditure" and "market dynamics enhancement".

The development of the programme is based, therefore, on three main action lines: (1) frame contracts, (2) support for PA specific needs, (3) marketplace, supported by an advanced IT platform using Oracle Technology.

The contracting authorities have to consider framework contracts as a benchmark; if they do not achieve better prices on the market than prices of framework contracts, they are required to use the framework contracts awarded by Consip.

The main results achieved in 2005 were as follows: 
- $\quad$ Around 45,000 "purchasing points" within the entire public administration had the opportunity to procure through Consip.

- $\quad$ Framework contracts covered EUR 13.688 billion of public expenditure and the purchase value of active framework contracts was EUR 945 million.

- $\quad$ The e-marketplace had an overall purchase value of EUR 29.8 million involving 9,667 transactions.

Other activities/results included offering a prize for Italian universities willing to set up a Masters course in e-procurement. This is directed at graduate students, civil servants and private sector tenderers. In 2005 two universities started such a programme and 30 students registered.

The Info Gate initiative is a broad co-operation with national and local enterprise associations. It aims to provide constant and permanent support to enterprises, especially the SMEs, across the whole country on the different aspects of the Rationalisation Programme on Public Spending for Goods and Services. The actors involved (Consip, national and local enterprise associations) develop structures that support enterprises' participation in the programme. In 2005 around 100 info gates were set up and 12 kick-off events organised. Consip provides continuous assistance to the info gates through an e-mail address, a call centre, a newsletter, a CD, and a call and web conference.

Consip sends monthly, quarterly and annual data reports to the Ministry of Economy and Finance on the rationalisation programme for goods and services. In 2005 the budget assigned to Consip for the rationalisation programme was equal to EUR 49.2 million (exclusive of VAT). The budget is part of the general ministerial budget and results from a fixed quote covering the fixed costs of the programme (i.e. personnel), and a variable quote covering the costs of innovative strategic projects.

Drafting primary legislation is the responsibility of the Parliament and the Council of Ministers, whereas the drafting of secondary legislation is done by the Ministry of Infrastructure, the regions, and the self-governing provinces. The Ministry of Infrastructure, the PWA and the Antitrust Authority develop standard procedures and routines. The Ministry of Infrastructure, the PWA, and the regions are in charge of drafting standard tender documents. Developing a procurement policy is the prerogative of the national and regional governments. The Ministry of Infrastructure and the PWA prepare guidelines and instructions. The contact point for the Commission is the Department for Community Policies, which also takes care of the national contribution to EU advisory committees. The Antitrust Authority, Department for Community Policies, Consip and the PWA (each respecting their own duties) all participate in the PPN (Public Procurement Network) adoption and fair enforcement of EU directives, instructions and suggestions on public procurement. The Italian Statistic Centre (ISTAT), and the Institute of Studies and Economic Research (ISAE) are among the many organisations collecting statistical and other data. The PWA and the Antitrust Authority advise the government on public procurement policy. Legal and other advice for contracting entities, utilities, and tenderers is provided by the Ministry of Infrastructure and the PWA. Apart from works contracts, where the PWA is the fining authority, the Antitrust Authority may impose fines.

There are public procurement units in regional ministries, provinces and districts, and there are municipal public procurement offices or offices of groups of municipalities. Each local entity has a procurement office, the size of which depends on the volume of procurement carried out.

\section{Latvia}

Latvia is found to have a centralised public procurement structure with the Procurement Monitoring Bureau being the main institution together with the Ministry of Finance, which is responsible of drafting legislation. However, important tasks are carried out by other institutions, 
such as the Bureau for the Prevention and Combating of Corruption, the State Audit Office, the Ministry of Economics and the Central Finance and Contracting Agency. In 2006 the government also established the Agency for Electronic Procurement.

The Procurement Monitoring Bureau (PMB) is a state administrative institution subordinate to the Ministry of Finance. It operates in accordance with the PPL, the regulations of the Procurement Monitoring Bureau, and other legislation. The PMB is responsible for monitoring procurement compliance with legal requirements. It also develops standard procedures and routines, and drafts standard tender and contract documents. It develops the national procurement policy and prepares guidelines and instructions. It reviews complaints on procurement procedures. It is also the contact point for the Commission, organises the national contribution to EU advisory committees, PPN participation, the national contribution to UNCITRAL and the GPA (with the Ministries of Economics and Finance), and other international representation. Other duties include preparing an annual report to the government on the functioning of the public procurement system (with the Ministry of Finance); collecting statistical and other data; giving permission for less competitive procedures, the use of exceptions, extensions, the use of the accelerated procedures, etc. (with Cabinet of Ministers and the contracting authorities); and preparing guidelines (nine prepared in 2005). The PMB is also responsible for administering the national public procurement bulletin, including publication and checking adverts which do not fulfil the requirements $(9,884$ in 2005); communicating notices of contracting entities and utilities to the OJ (1,592 in 2005); and publishing and distributing information on legislation and policy (also published in the official journal of the Ministry of Finance, Latvijas Vēstnesis). The PMB advises the government on public procurement policy. It also provides advice on framework agreements. Moreover, it provides legal and other advice for contracting entities, utilities, and tenderers and organises a national training programme for them. In 2005, 59 seminars with a total of 2,025 participants were held. The PMB also participates in national and international academic and other events on public procurement law, economics, and policy (24 events were attended in 2005).

The head of the PMB represents the bureau, decides on spending, issues internal guidelines, and appoints and dismisses officers and employees. The deputy head represents the PMB in the absence of the head. The directors of the departments are responsible for the work of their departments. The head of the PMB is appointed by the Minister of Finance after confirmation by the Cabinet of Ministers; the deputy head and the directors are appointed by the head. The Complaints Review Commission (CRC) is constituted by the order of the head for each individual complaint. There are three departments along with the CRC:

1. The Legal Department (8 staff) examines tenderers' complaints and represents the $\mathrm{PMB}$ in court in cases where CRC decisions are subject to appeal.

2. The Methodology Department consists of a director and three divisions:

- Methodology Division (2 staff), which prepares explanations of the application of the PPL and advises contracting entities and tenderers about the application of the PPL and other relevant rules.

- Legislation and European Issues Division (3 staff), which prepares drafts of laws and regulations.

- Control Division (2 staff), which monitors the application of the PPL and examines the compliance of procurement procedures with the PPL for tenderers' applications which cannot be handled in the CRC. It also gives its opinion about compliance of procurement procedures with the PPL on request from different state institutions. 
3. The Information Department (10 staff) consists of a director and two divisions: Procurement Announcement and Statistics (7 staff), and Procurement System Development (2 staff). The former division publishes contract notices and decisions and collects and examines statistical reports of contracting authorities. The latter deals with procurement system development issues.

The CRC deals with tenderers' complaints and decides on the permission or prohibition of entering into a procurement contract (at least three staff members). The $\mathbf{3 2}$ staff of the bureau comprises 18 civil servants and 14 other employees. Approximately $50 \%$ have a legal background and about $25 \%$ have a background in economics. All are familiar with public procurement, except for the business and administrative personnel and the accountants. The 2006 budget of LVL 1,362,006 (EUR 1,963,386) is part of the state budget, with additional foreign financial assistance of LVL 2 million (EUR 2,883,080).

Certain functions are carried out by other institutions. The Electronic Procurement State Agency (10 staff) was established on 2 January 2006 by a statute of the Cabinet and is responsible for organising and managing electronic procurement systems. It is partly dependent on and subordinated to the Minister for Special Assignments for Electronic Government Affairs. The director directs the work of the agency, managing its day to day running, preparing a strategy, representing the agency, recruiting and dismissing employees, and taking responsibility for spending the financial resources. The director is appointed by the minister through an open competition announced in the official gazette. There is a Procurement Division with a Procurement Section dealing with legal issues of new e-procurement systems, and a Public Relations Section. The Technical Supply Division covers IT issues and maintains the e-procurement system. The agency is partly financed through the state budget and partly through income from the agency's paid services and from foreign financial assistance. For contracting authorities the use of electronic procurement systems is free of charge.

The Bureau for the Prevention and Combating of Corruption is responsible for evaluating conflicts of interest and corruption in public procurement procedures and for prosecuting cases of corruption and other criminal offences in public procurement cases. The PMB and this bureau cooperate in the public procurement field. They may audit procurement entities.

The State Audit Office of the Republic of Latvia is an independent collegial supreme audit institution. It is a fundamental element of the state financial system, serving the interests of society by providing independent assurance on the effective and useful use of central and local government resources. The State Audit Office is one of six constitutional state institutions in Latvia. One of its tasks is to audit the public procurement activities of contracting entities.

The Ministry of Economics is responsible for concessions and PPP.

Ex ante control of public procurement contracts is a function of the Central Finance and Contracting Agency, with 263 contracts subject to this form of control in 2005.

Drafting primary and secondary legislation is the responsibility of the Ministry of Finance. Some interest groups (e.g. the Latvian Building Association, Latvian Association of Local and Regional Governments, Latvian Authorised Automobile Dealers Association, Latvian Insurers Association and the organisation Green Liberty) contribute to the development of the public procurement system by preparing procurement documents or participating in the legislative process.

There is no single central purchasing organisation. In 2004 there were 20 contracting authorities that conducted 128 centralised purchasing procedures for 134 other contracting entities. In 2004, LVL 21.7 million (EUR 31.3 million), or $4 \%$ of the public procurement market, were subject to central purchasing. 
The judicial review of public procurement decisions is conducted though the administrative courts.

\section{Lithuania}

Lithuania is found to have a centralised public procurement structure with the Public Procurement Office (PPO) carrying out most relevant functions. However, some functions are carried out by other institutions, most notably the Ministry of Economy, often in co-operation with the PPO.

The Public Procurement Office is responsible for preparing guidelines and instructions, preparing an annual report to the government on the functioning of the public procurement system, and collecting statistical and other data. From 2007 it will administer PPO qualification lists. Other tasks include providing legal and other advice for contracting entities, utilities and tenderers, and organising a national training programme for the public and utilities sectors and tenderers. However, private consultants are also active in the field. In 2005 the PPO organised 11 seminars for 225 participants from contracting authorities and suppliers, spending about EUR 78,000 on this activity. Representatives of the PPO participated in five national and international academic and other events on public procurement law, economics and policy.

The Ministry of Economy is responsible for drafting primary legislation, developing a procurement policy and advising the government on public procurement policy. It is the contact point for the Commission and in charge of the national contribution to the GPA. The Ministry and the PPO together are responsible for the national contribution to EU advisory committees, PPN participation, and the national contribution to UNCITRAL. Drafts of the legislation are made available on the Internet. Drafts of the legislation are also submitted to respective ministries, municipal institutions and associations of entrepreneurs who have the opportunity to comment. This process is stipulated in the Regulation on Government Activity.

Drafting secondary legislation is the responsibility of the PPO and the respective ministries. Developing standard procedures and routines and drafting standard tender documents and contract documents is done by the PPO in co-operation with other institutions, e.g. the Central Project Management Agency.

At the moment there is no central purchasing body but the government is planning to adopt appropriate decisions.

A limited level of control of public procurement procedures is carried out by the PPO. Following a complaint to the contracting entity, the PPO acts as an appeals board. This is in the context of an administrative review of public procurement decisions starting in February 2006, but only regarding particular aspects of proceedings. However, review bodies for the dissolution of disputes between tenderers and contracting entities are the civil courts. Two contracts were subject to judicial review in 2005. Fines can be imposed on the officials directly involved in procurement procedures and not on contracting authorities. Moreover, they can be excluded from membership of a tender committee for a year. In 2005, 22 contracting officers were subject to such disciplinary action. An audit of contracting entities' public procurement activities is carried out by the PPO and through state control.

\section{Luxembourg}

Luxembourg is found to have a semi-centralised public procurement structure with a dominant ministry conducting many of the relevant activities, as well as sharing some functions with other institutions.

The Ministry of Public Works is responsible for drafting primary legislation, developing a procurement policy, and generally advising the government on public procurement policy. The 
Chamber of Commerce and the Chamber of Handicrafts are given the opportunity to comment on draft public procurement legislation. The ministry is also the contact point for the Commission, responsible for the national contribution to EU advisory committees, PPN participation, the national contribution to the GPA, and other international representation. It prepares an annual report to the government and facilitates electronic procurement through a central Internet portal. The collection of statistical and other data is not centralised, except for statistics concerning the EU directives by the Ministry of Publics Works. Only civil servants work on public procurement matters in the ministry.

A number of activities are shared between the Ministry of Public Works and other institutions. The preparation of guidelines and instructions is conducted within the Ministry of Public Works, the Ministry of Interior Affairs and the Tender Commission. Both the Ministry of Public Works and the Ministry of Interior Affairs give legal and other advice to contracting entities and utilities. Legal and other advice for tenderers is provided by the Ministry of Public Works, the trade corporations and the Chamber of Commerce.

The drafting of standard tender documents for works is done by the Centre de Recherches. Permission for less competitive procedures, the use of exceptions, extensions, the use of the accelerated procedures, etc. can be obtained from the Ministry of Finance, Direction du Contrôle Financier (ex ante), for the most important contracts from the Tender Commission (ex ante) and from the Cour des Comptes (ex post).

There is no national public procurement bulletin and contracts are only published in national newspapers. The contracting entities themselves communicate their notices to the OJ. However, the notices from all contracting authorities existing in Luxembourg will be published on the central Internet portal hosted by the Ministry of Public Works.

A national training programme for the public and utilities sectors and tenderers is organised by the Institut National de l'Administration Publique (Ministry of Public Function and Administrative Reform). Courses are mandatory for trainees and part of continuing education.

The public procurement review body in the sense of Article 2 (8) Directive 89/665/EEC is the administrative court (with possibility for appeal), with urgent matters addressed to the president of the administrative court. There is also an Ombudsman-Mediator to resolve disputes between tenderers and the contracting entity, as well as with the Tender Commission.

There is no central purchasing body in Luxembourg, except for the supply of IT and office equipment for government bodies.

\section{Malta}

Malta is found to have a centralised public procurement structure with most functions exercised by the Department of Contracts (DC) in La Valetta. A few tasks are carried out by other institutions and contracting authorities at the local level. DC's central role as advisor to other contracting authorities and entities on public procurement is considered the main strength of the Maltese system.

The Department of Contracts is a dependent but integral part of the Ministry of Finance and was established on the basis of the Financial and Audit Act (1962) and Cap 174 Legal Notices 177 and 178 (2005). It has a staff of 40 full-time civil servants and a separate appeals board, an independent body composed of 4 part-time employees appointed by the Prime Minister. The DC is responsible for developing standard procedures and routines, for developing a procurement policy, drafting primary and secondary legislation, for the preparation of guidelines and instructions, contributing to EU advisory committees and the Maltese PPN, preparing an annual report to the government on the functioning of the public procurement system, collecting statistical and other data, and granting permission for the use of less competitive procedures and 
for the use of exceptions, extensions, accelerated procedures, etc. (although no applications were made in 2005), and advising the government on public procurement policy. Moreover, 47 published items on public procurement legislation and policy were distributed in 2005.

The DC is also the central purchasing unit for all contracts above MTL 20,000 (EUR 46,708) for 133 entities. This service is provided free of charge. Moreover, it is responsible for the administration of the national public procurement bulletin, including its publication and checking of contract notices. However, only $2.5 \%$ of all contracts are subject to central purchasing, the rest are conducted by local authorities. In 2005, 485 contracts were processed by the DC and 112 notices of contracting entities and utilities were communicated to the OJ through the DC. A major reform is the introduction of e-procurement across the Maltese government.

The DC is also in charge of the control of public procurement: 452 contracts were subject to ex ante control in 2005, and the DC assisted in the dissolution of 36 disputes between contracting entities and contractors; 34 cases were subject to review through the Appeals Board.

The provision of legal and other advice for contracting entities and utilities is shared between the DC and the Attorney General (Minister of Justice), whereas legal and other advice for tenderers is mainly provided by the Chamber of Commerce. The DC, together with the contracting authorities themselves, is responsible for drafting tender and contract documents. Together with the Department of Economic Policy, it is in charge of the national contribution to the GPA. The Ministry of Finance is responsible for drafting primary and secondary legislation. The contact point for the Commission is the Maltese Permanent Representation to the EU.

Malta has no blacklists, qualification lists, lists of certified tenderers, lists of certified public procurement trainers, training bodies or companies. Neither does it have any research programme on public procurement law, economics or policy; nor does it participate in national and international academic and other events on public procurement law, economics or policy or examine procurement officers.

The training function of the $\mathrm{DC}$ is rather limited. One two-day national training programme for 40 officials was conducted in 2005. Two officials of the EU Unit were given specific training by in an Introductory and Practitioners Seminar on European Public Procurement Rules, Policy and Practice organised by the European Institute of Public Administrations (EIPA) in Maastricht, and another two officials attended a training seminar on FIDIC General Conditions of Contract in Brussels.

The DC is subdivided into the following sections: Pre-Contracts (7 staff), Post-Contracts (2 staff), the Secretariat to the General Contracts Committee (2 staff), the EU Unit (7 staff), and the General Administration (10 staff). The Pre-Contracts section caters for all administrative procedures, from the publication of the tender notice to the issuing of the letter of acceptance or the conclusion of the contract. The Post-Contracts section caters for any issues arising during the implementation of the contract, including litigation. The Secretariat to the General Contracts Committee is responsible for vetting the evaluation reports prior to their submission to the Committee, as well as debriefing unsuccessful bidders. The EU Unit is responsible for all procurement financed through EU funds. The General Administration deals with all of the DC's accounting and human resources.

The educational background of the 40 staff varies from secondary education to university graduates. Sixteen employees are familiar with local and EU public procurement, as well as with more technical aspects of procurement. The fact that procurement officials and contracting officers are not required to have a specific formal educational background in public procurement is considered a weakness of the Maltese system. The DC is financed from the general government budget; this amounted to MTL 493,000 (approximately EUR 1.15 million) for the 2006 financial year. Budget estimates are prepared by September each year and forwarded to 
the Ministry of Finance. The budget is adopted according to the country's priorities. The revised budget is approved by parliament near the end of the calendar year.

\section{Poland}

Poland is found to have a centralised public procurement structure with one main institution for all or most functions at the national level (the Public Procurement Office).

The Polish Public Procurement Office (PPO) was created on 1 January 1995, following the adoption of the Act on Public Procurement (PPL) on 10 June 1994. The PPO plays a policy making and co-ordinating role for the entire public procurement system. The key duties of the PPO are to publish the official Public Procurement Bulletin (PPB, Biuletyn Zamówień Publicznych) in which contract notices (of value above the thresholds defined in the PPL) are published, to prepare drafts of legislative acts in the field of public procurement, to arrange appeal proceedings under the PPL, to control tender procedures conducted by contracting authorities, to prepare training programmes, organise and inspire training events in the field of public procurement, and to advise the government on public procurement policy.

According to the PPL the president of the PPO shall be appointed by the Prime Minister from among candidates selected in an open competition. Only a person with a degree and knowledge of the functioning of the public procurement system may be president. The president's term of office is five years, renewable once. He or she remains in office until the appointment of a successor. The president has the following roles:

- $\quad$ to prepare drafts of normative acts on public contracts;

- $\quad$ to take decisions on individual issues stipulated in the PPL;

- $\quad$ to publish notices stipulated in the PPL in the PPB;

- to keep and publish a list of arbitrators examining appeals against dismissal or rejection of protest lodged in contract award procedures in the PPB;

- $\quad$ to keep and publish a list of organisations authorised to submit law enforcement measures in the PPB;

- $\quad$ to ensure the functioning of the system of legal protection measures;

- $\quad$ to prepare training programmes, and organise and encourage training in the field of public procurement and to prepare and disseminate standard criteria for assessing the substance of the training;

- $\quad$ to disseminate standard forms of public procurement contracts, regulations and other documents used in awarding public contracts;

- $\quad$ to watch over observance of the public procurement system rules and in particular to check the contract award process within the scope stipulated in the PPL;

- $\quad$ to disseminate the principles of professional ethics of people performing tasks within the public procurement system;

- to ensure uniform application of legislation on public contracts by, in particular, dissemination of the courts and the Constitutional Tribunal judgements;

- $\quad$ to maintain international co-operation on issues relating to public procurement;

- $\quad$ to analyse the functioning of the system of public procurement;

- $\quad$ to prepare and submit to the (Polish) Council of Ministers and to the European Commission annual reports on the functioning of the system of public contracts. 
The current two vice presidents of the PPO are appointed and recalled by the Prime Minister on request of the president of the PPO. The president is supported by a staff of 115 , organised into 7 departments.

The Legal Department (19 staff) provides both internal and external legal services for the PPO through 4 units: Legislation, Legal Opinions, Administrative Decisions, and European Law. The activities of the Legislation Unit (3 staff) include preparing draft legislation and participating in the legislative process for legal acts prepared by other governmental institutions related to public procurement. There is an obligation to consult about draft legislation with social partners, such as NGOs, trade unions and employers' organisations. Special consultative meetings are held. Draft legislation is also made available on the PPO website. The Legal Opinions Unit (5 staff) focuses on explaining and interpreting provisions of the PPL, disseminating legal interpretations and preparing general contract terms, standard contract patterns and instructions concerning contract award procedures. The Administrative Decisions Unit (5 staff) prepares administrative decisions to be issued by the president pursuant to the PPL and analyses related data. The activities of the European Law Unit (3 staff) include monitoring the compliance of the PPL with the EU directives, preparing Poland's positions with regard to ECJ cases concerning public procurement, and analysing changes and developments in international law and agreements in the field of public procurement. Standard tender and contract documents are drafted by external consultants and then verified and updated by the Legal Department.

The Control Department (23 staff) carries out the tasks related to the president's control powers provided for in the PPL and organises PPO co-operation with other control institutions, such as the Supreme Chamber of Control or the regional audit chambers. This department is responsible for carrying out ex ante and ex post control of particular contract award procedures on the basis of information and documents obtained from awarding entities and other sources. In 2005, 371 contracts were subject to ex ante control. The department is divided into four units: ex ante Control of Contracts for Supplies and Services; ex ante Control of Contracts for Works; ex ante Control of Contracts in the Utilities; and ex post Control.

The Training and Publications Department (17 staff) is responsible for training events, disseminating training materials, and editing the PPB. It has two units: the Training and Educational Publications Unit and the PPB Unit. The Training and Educational Publications Unit (8 staff) disseminates information on public procurement principles and provisions among procuring entities and tenderers, organises seminars and training events for arbiters, elaborates publications and guides on the application of public procurement provisions, and provides the PPO website service. It also participates in implementing support programmes which aid the development of the public procurement system in Poland. It checks and disseminates publications prepared by PPO staff or external consultants. In 2005 it organised some 80 training courses for 2,500 people financed through the PPO budget, and 187 courses for 5,400 people financed by the PHARE budget. The PHARE budget for training and publications was EUR 1.5 million (total budget of an assistance project). The main tasks of the Public Procurement Bulletin Unit (9 staff) are related to publication of the PPB (pursuant to Article 14a PPL), which is the official source of information on public contracts in Poland. The PPB Unit receives and checks the formal correctness of procurement notices to be published in the Bulletin, monitors the dissemination of paper issues of the Bulletin and prepares its electronic version to be placed on the PPO website (7 staff). In 2005, 36,029 notices were published. Polish contracting authorities and entities published 12,380 contract and design contest notices in the OJ EU in 2005.

The International Cooperation, Studies and Analyses Department (6 staff) is responsible for the PPO's international contacts and its co-operation with relevant authorities in other countries and international organisations dealing with public procurement issues. The department gathers 
and disseminates information about foreign and international public procurement provisions and procedures. It also analyses the functioning of the Polish public procurement system, the procurement market and its prospective development. It prepares annual reports on the functioning of the public procurement system, which are then submitted to the Council of Ministers (3 staff). The department is also responsible for preparing statistical reports to be submitted to the European Commission pursuant to the relevant provisions of the EU directives. Finally, the department collects statistical and other data (3 staff).

The Bureau of Appeals (11 staff) carries out tasks related to appeal proceedings under the PPL and provides services for the appeal panels. Complaints against procurement decisions have to be made to the contracting entities in question (first instance) before the independent appeal panels of the PPO review the case in the second instance. The regional courts (entirely separate from the PPO) review public procurement cases in the last instance. Appeals are examined by panels consisting of three arbiters appointed by the PPO President by means of a public drawing. In 2005 there were 4,094 appeals, 563 of which went to the third instance. The bureau's activities cover: maintaining the register of arbiters and the archives of appeal cases, preparing drafts of decisions (to be issued by the president) about the entrance into and removal from the arbiters' register. This unit also collaborates with the Training and Publications Department for providing training for arbiters.

The Organisational and Financial Bureau (23 staff) supports the PPO's accounting, administrative and organisational aspects. Tasks include developing draft PPO budgets, investment plans and schedules of expenses, and preparing reports and information on budget execution. The bureau receives and dispatches external correspondence, gathers and stores official documents, and manages the PPO archives. This unit also administers the internal computer network as well as the PPO website.

The Legal Department (European Law Unit) (3 staff) is the contact point for the Commission and is responsible for the national contribution to EU advisory committees. PPN participation (3 staff) and the national contribution to UNCITRAL (1 staff) are also organised by the PPO through its International Cooperation, Studies and Analysis Department. The national contribution to the GPA (3 staff) is conducted through the Legal Department (European Law Unit). Other international representation is the responsibility of the International Cooperation, Studies and Analysis Department. Legal and other advice for contracting entities, utilities and tenderers is provided by the PPO help desk and Legal Department (Legal Opinions Unit), which provides opinions and interpretations of the public procurement legislation. Legal and other advice is also provided by private consulting firms.

All civil servants and almost all employees of PPO have a university degree and many are lawyers. In particular the staff of the European Law Unit (3 people) and part of the staff of the International Cooperation, Studies and Analyses Department (3 people) are familiar with EC law. The entire staff of the Legal, Control, International Cooperation, Studies and Analyses, and Training and Publications Departments are familiar with the PPL. Financial and technical aspects of procurement are known to some staff with experience in contracting authorities. The original budget for the PPO (i.e. the funds provided in the state budget) in 2005 was nearly PLN 9.5 million (approx. EUR 2.37 million). This budget is part of the state budget and prepared in accordance with budget law. The costs of the appeal proceedings are covered by the compulsory registration fees.

The Public Procurement Council (PPC) is an advisory body to the PPO President. The PPC is composed of 10 to 15 members appointed by the Prime Minister. There are currently 14 members. Parliamentary groups, national self-government organisations and national entrepreneurs' organisations propose candidates to the PPC. The Prime Minister appoints members of the PPC. The chairman of the council is appointed by the Prime Minister from 
amongst its members. The vice chairman is appointed from amongst council members. The PPC's role is to express its opinions on particularly important matters of the public procurement system presented to it by the PPO President; give its opinion on normative acts concerning public contracts; give its opinion on the PPO President's annual reports concerning the functioning of the public contracts system; and to establish the principles of professional ethics for people performing tasks specified in PPL within the public contracts system.

A limited number of tasks are carried out outside the PPO. Prosecuting cases of corruption and other criminal offences in public procurement cases is the responsibility of the Public Prosecutors. In 2005 the PPO President informed the Agent for Public Finance Discipline of about 18 violations. The agent is empowered to take disciplinary action against contracting officers who violate the PPL. On the basis of an amended PPL which entered into force on 25 May 2006, the Prime Minister may designate an institution to play the role of central purchasing body for other contracting entities. As this is a new regulation, there is no body designated to be a central purchasing body. The regional courts are in charge of judicial review.

\section{Portugal}

Portugal is found to have a decentralised public procurement structure involving many institutions. However, the system is expected to evolve into a more centralised procurement structure. Most notably, there is a plan to establish an Unidade Nacional de Compras (UNC, Central Body for Public Procurement). This would co-ordinate public procurement at a national level and ensure the co-ordination, monitoring and implementation of national policies amongst the public procurement departments of the various ministries, as well as lead the e-procurement process. Portugal has also partly organised its public procurement structure vertically with the Câmara Municipal e Junta de Freguesia and Regiões Autonomas de Açores e Madeira, which have autonomy for public procurement in their area.

Currently the Direcção Geral dos Assuntos Comunitários (DGAC) is the contact point for the Commission and is responsible for the national contribution to UNCITRAL. The national contribution to EU advisory committees is organised by the Direcção Geral do Património (DGP) for goods and services and the Instituto de Mercados de Obras Públicas e Particulares Imobiliárias (IMOPPI) for works. DGAC, DGP and IMOPPI participate in the PPN, whereas the national contribution to the GPA is co-ordinated though the DGAC and the DGP. DGP and IMOPPI collect statistical and other data.

Drafting primary legislation, developing standard procedures and routines, and developing a procurement policy are all tasks of the government. Departments designated to draft legislation send drafts to the cabinet minister, who then submits the proposal to the interested parties who can make suggestions to improve the document. The government has also issued a legal act for standard tender documents. Some information is provided by the portal www.compras.gov.pt, but there is no help desk for public procurement as such. There is no national training programme, although the Instituto Nacional de Administraçao (INA) provides some related courses.

There are a number of central purchasing bodies. A small unit which is part of the Ministry of Finance and Public Administration (Direcç̧ão de Serviços do Aprovisionamento Público DSAP, integrated into the Direcção Geral do Património - DGP) launches international procedures to establish economics and technical conditions for a number of products that are significant for the general budget. This unit also has functions other than procurement. Other procurement entities purchase products under the conditions of framework agreements established by DSAP for computers, printers, software, networks, clothes, copiers, paper and other office articles, oil, mobile telephone services, vehicles and hotel accommodation/transport services. The Ministry of Education also has units which purchase products for certain schools. There is a similar unit for the health sector (IGIF - Instituto de Gestão Financeira da Saúde), 
reporting directly to the Ministry of Health. In 2005 contracts worth some EUR 224 million were awarded on the basis of these framework agreements, in a procurement market worth some EUR 1,556 billion. The DGP facilitated 440 framework agreements.

The DGP (which has nine full time civil servants dealing with public procurement) has a director general appointed by the minister. The heads of the other institutions are also appointed by ministers. The budgets of the various institutions are part of the state budget.

\section{Romania}

Romania is found to have a centralised public procurement structure clearly dominated by the National Authority for Regulating and Monitoring Public Procurement. Other key institutions are the General Inspectorate for Communication and Information Technology, the Unit for Verification and Co-ordination of Public Procurement of the Ministry of Finance, and the Council for Resolving Disputes.

The National Authority for Regulating and Monitoring Public Procurement (NARMPP) reports directly to the Prime Minister. NARMPP functions include: advising the government on public procurement policy; drafting primary and secondary legislation, standard procedures, contract forms and general conditions for contracts; facilitating framework agreements, PPP, and concessions; and giving legal and other advice to contracting entities and utilities. It fines contracting authorities that violate public procurement rules. The NARMPP prepares an annual report to the government on the functioning of the public procurement system, based on statistical and other data. It publishes information on legislation and policy. It also has training and research functions, organises a national training programme for the public and utilities sector, and facilitates independent teaching and research at universities, training colleges and through private companies. Moreover, it organises a research programme on public procurement law, economics and policy and participates in national and international academic and other events on public procurement law, economics and policy.

E-procurement is operated by the NARMPP (policy-wise) and the General Inspectorate for Communication and Information Technology (GICIT), which is responsible for electronic facilities. The NARMPP administers the National Public Procurement Bulletin, including rejecting adverts which do not meet requirements. The GICIT administers the technical publication of notices and communicates the notices of contracting entities to the OJ (this involves about 30 staff).

NARMPP was established in July 2005 and became fully operational in November 2005. The legal foundation of the NARMPP is Law 111/2006 which approved Emergency Ordinance $74 / 2005$. It is headed by a president and a vice-president subordinated to the office of the Prime Minister. Its budget is part of the general state budget and amounts to EUR 2.5 million annually (2005 figure). The NARMPP is composed of four departments: Policy and Regulation, Operations Development, Monitoring and Supervision and finally Economy and Administration. The latter is headed by the general secretary of the NARMPP. There is also an advisory board. The NARMPP currently has a full-time staff of 70 but the total number of positions to be filled according to the law is 125 . Ninety per cent of employees have a university degree in various subjects, including economics, law and engineering. The public administration rules for promotion apply to the NARMPP. Top and middle management benefited in 2005 from continuous training organised with the support of SIGMA. Moreover, there was a twinning project worth EUR 400,000 in 2002, and technical assistance projects worth EUR 1.5 million in 2003 and EUR 2 million in 2006 (see: www.anrmap.ro).

The Unit for Coordination and Verification of Public Procurement (UCVPP) of the Ministry of Public Finance performs ex ante control of public procurement contracts. This was started only 
recently in view of Romania's accession to the Union. About 130 staff members are working on this form of control in the ministry.

The National Institute for Administration organises training sessions for NARMPP staff.

The public procurement review body, in the sense of Art.2 (8) Directive 89/665/EEC, is the National Council for Resolving Legal Disputes (50 staff). Their decisions can be appealed to the Court of Appeal. The prosecution offices deal with cases of corruption and other criminal offences in public procurement cases. The Court of Audit controls the public procurement activities of contracting entities, and executes the judicial review of public procurement decisions.

\section{Slovak Republic}

Slovak Republic is found to have a centralised public procurement structure where the Office for Public Procurement (OPP) is in charge of most functions. Moreover, certain functions are vertically organised: the OPP has two regional branch offices but they lack legal personality.

The Office for Public Procurement was created in 2000 by the Act on Public Procurement (APP) No. 263/1999 Coll. However, the present legal foundation of the OPP is Act No 25/2006 of 14 December 2005, which represents the Slovak implementation of the new EU Directives. The OPP develops procurement policy, prepares guidelines and instructions, and drafts primary and secondary legislation. This process involves the governmental approval of an annual Plan of Legislative Tasks, after which the OPP prepares drafts according to this plan. Ministries and central state bodies can make comments. After taking all these comments into account, the draft is submitted to the government, which approves it before sending it to parliament. The law is then signed by the President and finally published. The tasks of the OPP also include preparing concepts for public procurement, administering and surveillance of public procurement, the annual submission of a report on its activities to the government and, upon request, to a committee of the parliament. The OPP notifies the conversions of financial thresholds for contracts above the thresholds of the directives in Slovak Crowns, maintains a mandatory list of tenderers, draws up programmes of professional and continuous education in public procurement, issues certificates of professional qualification, runs a list of professionally qualified persons, provides methodology guidance and develops standard procedures and tender documents, imposes fines and performs other activities under the APP. The OPP is also the contact point for the Commission, and contributes to EU advisory committees and to working groups on e-procurement and statistics. The OPP is a member of the PPN and prepares the national contribution to the GPA. It contributes to the CIRCA working groups and to the monitoring of the EU Public Procurement Learning Lab, OJ EU, SIMAP and TED activities. It has operating contacts with partnership institutions in EU Member States, third countries and other partners (Turkey, Romania, CARDS countries, USA, World Bank). The OPP monitors framework agreements according to tender notices for statistical purposes only. The Annual Information on Statistical Evaluation of the Public Procurement Process is usually submitted to the government in late May. The OPP issues the National Public Procurement Bulletin (both paper and electronic versions) and also checks whether notices fulfil the requirements. In 2005 , 13,052 contracts were published. Other publications include the Journal of Public Procurement (250 issues), an annual international conference, media interviews and conferences, as well as collaboration with journalists in the daily press and for 119 publications. Each contracting authority or entity is responsible for the correct publication of its tender notices at the national and EU levels. In 2005 the PR Officer responded to 786 requests for information.

The OPP has developed a National Training Programme delivered by certified independent training centres. In 2005, 723 participants attended 45 three-day courses. The OPP facilitates independent teaching and research at universities, training colleges, and through private companies. It prepared and published presentations on the new APP in 2005 for ministries and in 
2006 for trainers. Since February 2006, according to the new 2005 APP, "the contracting authority shall be obliged to notify the OPP in writing about commencement of a negotiated procedure without a publication immediately after the dispatch of the invitation to negotiate, however, not later than 14 days before the conclusion of a contract." The OPP is responsible only for monitoring and review of the correct use of this less competitive method and not for giving any permission.

The OPP is a Public Procurement review body in the sense of Article 2 (8) Directive 89/665/EEC and Article 2 (9) Directive 92/13/EC. It fines contracting authorities that violate public procurement rules: in 2005 there were 856 cases and 22 contracting authorities were fined. The dissolution of disputes between contracting entities and contractors is managed by the OPP's Division of Internal Provisions and Decisions on Protest, which has received 1,089 demands, of which 108 cases are above EU thresholds. Sixteen appeals have been submitted to the Appeals Board, which has requested the collaboration of independent experts. The OPP brings proceedings for judicial review in courts of law against violations of public procurement law. The police and Prosecutor manage cases of corruption and other criminal offences in public procurement cases. The public procurement activities of contracting entities are audited by OPP internal control and by an external auditor. Disciplinary measures enforced by the OPP may affect individual contracting officers: in 2005 they were 140 such measures. The OPP does not perform ex ante control on contracts.

The OPP is not in charge of judicial review of public procurement. Such decisions are made by the court, which had to deal with 22 cases in 2005.

The OPP is situated in Bratislava and headed by a chairman who is appointed and removed by the government. The deputy chairman is appointed and removed by the government following a proposal by the chairman. Their office period is five years and renewable once. According to Article 111 Act No. 25/2006, the term of office of the chairman and deputy chairman will terminate upon the expiry of his or her term, by resignation from the office, by removal from the office by the Slovak government, or by death or in declaration of death. The government can remove the chairman and the deputy chairman if he or she has been lawfully convicted of a malicious offence, has been deprived of his or her legal capacity by a lawful decision of a court or his or her legal capacity has been restricted, holds an office or performs an activity incompatible with the office of chairman or deputy chairman, has not exercised his or her office for a time exceeding six successive calendar months. The government may suspend the execution of office of the chairman and deputy chairman where criminal prosecution has been commenced against him or her relating to the execution of the office. The OPP is subdivided into the Office of the Chairman, the Office of the Deputy Chairman, the Division of Legislation and Methodology, the Division of Journal and Lists, the Division of Internal Provisions and Decisions on Protest, the Division of Inspection, the Department of European Integration and International Cooperation, the Office of State Service, the Division of Economy and IT, the Commissions on Remedies, and the Appeal Board of the Office of Deputy Chairman. Some organisational changes occurred at the beginning of 2006 and this is the actual organisational chart of the OPP. The office has a staff of about 110, of which 90 are civil servants and 20 employees. Almost all staff has a college or university education. Its budget is a separate section of the state budget (http://www.finance.gov.sk/EN). In 2005 it was SKK 58.42 million (EUR 1,475 million). Fees, fines and bails are revenues for the state budget.

The OPP has three local branches in Nitra (3 staff), Žilina (4 staff), and Košice ( 5 staff). These branch offices have no separate legal personality.

The OPP is not in charge of central purchasing functions. Purchasing is done by the 7,000 contracting authorities and entities which are fully responsible for their public procurement activities. The government has plans to centralise purchases of goods and services and to 
promote the use of electronic facilities in public procurement. The OPP neither facilitates concessions or PPP, nor administers a blacklist. It keeps a qualification list, which included 4,149 entrepreneurs in 2005 (679 natural and 3,470 legal persons), and a list of certified procurement officers. In 2005, 56 examinations were held and out of 745 applicants, 697 persons were added to the OPP's list, totalling 6,170 qualified persons in the Slovak Republic.

\section{Slovenia}

Slovenia is found to have a semi-centralised public procurement structure. The main public procurement institution, designated as such by an Act of Parliament, is the Department for Public Procurement, Public Utilities and Concessions (DPPUC), which is a dependent part of the Public Property Directorate of the Ministry of Finance (MoF). The DPPUC is not the only public procurement institution, since the Ministries for Public Administration and for Health also cover certain tasks.

The DPPUC performs legislative and policy functions such as drafting primary and secondary legislation and developing a procurement policy, as well as standard procedures and routines, drafting standard contract documents and preparing instructions. It gives legal and other advice to contracting entities, utilities and tenderers. In its role of drafting the national procurement legislation, the DPPUC consults stakeholders from both sides, i.e. purchasers (mainly bodies governed by public law on the central level) and sellers (Chamber of Commerce, the largest providers) through working groups at various levels. The DPPUC is the Slovene contact point for the European Commission and the national contributor to EU advisory committees, UNCITRAL and GPA. It participates in the Public Procurement Network. The DPPUC issues an annual report to the government on the functioning of the public procurement system and collects statistical and other data. It does not administer a qualification list or a blacklist. There is no authority approving single-source procurement or less competitive and transparent procedures. This responsibility lies with the contracting entity, which answers for its actions to the review and/or auditing authority. There are 155 contracting entities with a total procurement volume of EUR 108 million for 2005.

The DPPUC has a staff composed of eight full time civil servants with an academic background. There is a head of department but otherwise no sub-sections. The different tasks are divided between all members of staff. The finances of the department come from the general budget of the ministry and government.

The Official Gazette of the Republic of Slovenia is responsible for publishing procurement notices and checking whether adverts fulfil requirements. The national count of notices communicated in 2005 is not yet finalised.

There is central purchasing: purchases are aggregated for some goods and services for various government bodies at the central government level in the Ministry for Public Administration (for administrative units at the local level and some items such as IT, office furniture, and vehicles). The Ministry for Heath procures medical equipment and some goods for hospitals and other health care institutions.

The National Review Commission (NRC) is the public procurement review body in the sense of Article 2 (8) Directive 89/665/EEC. In 2005 the NRC audited 83 contracting authorities. No disciplinary measures were taken against contracting officers but 497 decisions were subject to judicial review. There is no ex ante control in the form of prior approval by the central procurement institution.

Civil servants responsible for public procurement participate in seminars run by private organisations. 


\section{Sweden}

Sweden is found to have a semi-centralised public procurement structure with a number of responsible central institutions as well as decentralised solutions at the local and regional levels. At the central level, the key procurement bodies are the NOU (Nämnden for Offentlig Upphandling) and the Ministry of Finance. The procurement institutions at the regional and municipal levels mainly provide legal and professional advice to contracting entities and initiate a number of development actions. It should be noted that many functions are carried out by the private sector.

The Ministry of Finance is responsible for drafting primary and secondary legislation and acts as the contact point for the Commission. The ministry has appointed a lawyer to contribute to UNCITRAL. There are now three civil servants in the ministry working full-time on procurement issues.

The NOU is a supervising body supporting the government. It is involved in policy-making, issues legal opinions, assists the government with international contacts, and responds on an advisory basis to complaints from tenderers or requests from the European Commission. It develops procurement policy and prepares guidelines, instructions and an annual report to the government on the functioning of the public procurement system. It advises the government on public procurement policy and provides information about the legislation and legal practice for contracting entities, utilities and tenderers. In 2005 NOU also organised a procurement conference for 500 participants. In the context of dispute settlement between contracting entities and tenderers, the NOU may give a non-binding opinion. However, it does not have the power to suspend proceedings or to award damages. The NOU is subordinated to the Ministry of Finance but is independent in its daily operations.

The NOU is a national board and the members are appointed by the government upon proposal by the various stakeholders. The entire board, with its eight members, is the collective head of the NOU. The members are representatives of both contracting authorities and tenderers. The chairman is a judge, being head of department from the Administrative Court of Appeal. The board meets once a month. The day-to-day operations are managed by the secretariat, which has nine or ten employees (mainly lawyers and economists with university degrees) and which is headed by a director. The secretariat has no subdivisions. In 2005 the NOU had a budget of about SEK 9 million (EUR 994,750), provided from the general governmental budget.

Together the Ministry of Finance and the NOU organise the national contribution to EU advisory committees, participate in the PPN and provide information about new public procurement legislation. The national contribution to the GPA is organised by the Foreign Ministry with the support of NOU and the National Board for Trade (Kommerskollegium). The NOU, with the help of the state agency Statistics Sweden, collects statistical data about public procurement.

Legislation is proposed by a committee of the government and is sent for consultation to authorities, local governments and any interested stakeholders, before a proposal is passed to the parliament. In December 2005 the minister responsible held a hearing with stakeholders, such as representatives of public purchasers, local governments, law-firms, the Chambers of Commerce, and the NOU.

Developing standard procedures and routines, drafting standard tender documents, and drafting standard contract documents are the tasks of various units.

The Competition Authority monitors competition and may in theory intervene in cases involving competition law or the misuse of procurement procedures. 
Administration of the public procurement bulletins (paper or electronic), including publication and checking adverts for fulfilment of requirements, is handled by private companies, such as Allego, Opic and others.

Some advice is provided by Co-ordination of Government Procurement and the Swedish Association of Local and Regional Government.

Training courses on public procurement are offered by the Swedish Association of Public Purchasers and Allego. There is one course for purchasers and a special course for lawyers in Stockholm and Linköping as a part of legal university education.

The NOU and the Competition Authority are at times involved in research, but there is no research programme.

Framework agreements are used in government and local government joint procurement. Any authority buying large quantities or having special knowledge in some fields can make a framework agreement to meet its own needs - and those of other authorities - for supplies or services. The Swedish Armed Forces, for example, has a framework agreement for travel and hotel accommodation; others buy most of their IT-equipment and services in this way. About $12 \%$ of all contracts are part of government framework agreements but there is no central purchasing institution. Electronic procurement is used in some cases, but there is no complete e-procurement procedure. There is mostly electronic ordering and invoicing.

Public procurement review bodies, in the sense of Article 2 (8) Directive 89/665/EEC, are the 24 administrative courts of law for review of award procedure before the conclusion of the contract, and the civil courts for damages. There is an arbitrator but his services have never been used.

There are plans for strengthening the monitoring system and developing a best practices unit. The details are not known yet. There will be new legislation sometime in the second half of 2007.

\section{United Kingdom}

The United Kingdom is found to have a semi-centralised public procurement structure, but with the Office of Government Commerce (OGC) as the key institution. However, a number of functions at the national level are shared between several bodies and the devolved regional governments of Scotland, Northern Ireland and Wales have their own institutions.

The OGC was established by ministerial decree in 2000 following a review of civil government procurement by Sir Peter Gershon, who became the organisation's first chief executive. The OGC was established as a dependent office of HM Treasury (Ministry of Finance), merging a number of previously distinct central procurement organisations, including the Buying Agency, the Property Advisors for the Civil Estate, the Central Computer and Telecommunications Agency and the Treasury Public Procurement Unit. The formation of OGC reflected specific recognition of the need for a strong central repository of expertise on procurement matters to assist the public sector to deliver better results from its commercial activities in support of the government's ambitious public service delivery targets. The OGC field of operation now extends beyond its original remit of central civil government and is playing a key role in driving forward the government's attempts to introduce ever-greater efficiencies into public administration. These include: cash savings, which are used to invest in front-line services; increasing the success rate of major public sector projects and programmes in part through the operation of a formal system of project status reviews; facilitating the effective functioning of the public procurement market, organisational administration and management. Most UK procurement-related legislation is secondary legislation. The lawyers from the Treasury Solicitor's Department who are based at the OGC are responsible for drafting legislation on direction from the OGC. Consultation typically involves the publication of a consultation document setting out the issue under consideration and the associated proposed initiatives. Responses are invited from interested 
stakeholders, with a deadline set for submission of responses. The responses are then assimilated and the proposed policy position revised as appropriate. The entire process is to be conducted in accordance with the Code of Practice on Consultation issued by the Better Regulation Executive of the Cabinet Office. Developing standard procedures and routines, standard tender documents, standard contract documents, and guidelines and instructions are part of the tasks of the OGC. However, other organisations are also engaged in this activity within their field of interest. The OGC develops the procurement policy and is the contact point for the Commission. It is responsible for the national contribution to EU advisory committees, PPN participation the national contributions to UNCITRAL and GPA and other international representation. There is no annual report to the government on the functioning of the public procurement system but the OGC fulfils a similar function. The collection of statistical and other data and the preparation of guidelines are other tasks of the OGC. About 10 formal documents were compiled in 2005. The OGC administers a list of certified procurement officers. The OGC publishes and distributes of information on legislation and policy. Around 10 individual items of guidance were published in 2005. Advising the government on public procurement policy is another important OGC function. Legal and other advice for contracting entities, utilities and tenderers is provided by the OGC (general advice, not case specific - contracting authorities are required to seek legal advice from their own lawyers). The OGC participates in national and international academic and other events on public procurement law, economics and policy: about 10 such events were held in 2005.

The OGC has a legal department, policy or central department, and organisation and finance department. The role of the OGC Procurement Policy Division (PPD) is to represent the UK on procurement matters to the European Commission, other EU partners and to the WTO and its members, and to assist UK public sector bodies to apply the rules in the UK. It also takes the lead on the government's policy of achieving value for money in public procurement. This role includes considering, advising and producing guidance on the scope to take issues, such as sustainability, into account within the legal and policy framework. The two main functional units of PPD are teams concerned with: 1) development of procurement policy, in particular in relation to EU and WTO matters, and 2) application of that policy, providing assistance to stakeholder organisations in the application of the policies which the other team has helped to shape. The PPD is overseen by a senior civil servant, supported by a Divisional Management Office, who reports to one of the executive directors on the OGC management board. The OGC Legal Services Team supports the activities of PPD along with the rest of OGC, providing advice on policy development and application from a legal perspective. There are about eight people in the OGC legal team. It is anticipated that in the financial year 2005-2006 OGC expenditure across the whole organisation will be around GBP 58 million (EUR 86.117 million). The PPD has been allocated a budget of over GBP 1 million (EUR 1.485 million) for the current financial year. These figures cover all running costs and only a proportion will be devoted to outside sourcing of goods and services. The OGC annual corporate budget is agreed with HM Treasury following discussions on estimates of the levels of resources required to deliver its business plan, which is a composite of the business plans of the individual organisational units. Individual business plans and budgets are considered by the OGC Investment and Implementation Board, which ensures that resources allocated to the differing elements of the organisation agree with corporate priorities. The PPD budget is also agreed in this way with other organisational units. The OGC currently employs around 500 people, mostly civil servants but also consultants; of these, only a small proportion is engaged in central procurement policy work - around 25 in all. The educational background varies. Most PPD staff have received professional training in procurement and most are familiar with EC and public procurement law. A high proportion of staff members are familiar with the financial and technical aspects of procurement. 
The National School of Government and the Chartered Institute of Purchasing and Supply collaborate to maintain and provide procurement training for public procurers. OGC provides input on the content of the training.

Various organisations are involved in the facilitation of framework agreements; most important are Buying Solutions (an OGC unit) and the National Health Service Purchasing and Supply Agency (PASA), but there are other bodies active in this area such as regional purchasing consortia in local government and the National Health Service. Buying Solutions had several hundred agreements in place. PASA had 4500. Partnerships UK and the 4Ps also facilitate PPP and concessions. Electronic procurement is managed by various organisations, including OGC Buying Solutions and the Department of Communities and Local Government. Buying Solutions oversees three main e-procurement schemes.

OGC does not act as a central purchasing body for the public sector. This function is fulfilled by OGC's Executive Agency, OGC Buying Solutions, which is self-funded though its own activities and has its own chief executive, although they are a member of the overall OGC management board. Public sector bodies are not obliged to use the services of Buying Solutions, however, if they believe they can achieve better value for money through not doing so.

Various organisations are involved in central purchasing - most significant are OGC Buying Solutions and the National Health Service Purchasing and Supply Agency (PASA). OGC Buying Solutions' functions extend to the whole of the UK public sector (over 1,000 distinct contracting authorities). PASA's field of operations is purely the National Health Service (around 500 contracting authorities). Total public sector procurement spend in 2005 was over GBP 100 billion (EUR 148.5 billion). Total spend through Buying Solutions in 2005 was more than GBP 2 billion (EUR 2.97 billion). Total spend through PASA during financial year 2004/05 was GBP 3.6 billion (EUR 5.35 billion). As noted above, there are other central purchasing bodies, such as local authority purchasing consortia.

The United Kingdom's review of procurement decisions is the responsibility of the national courts system, which is overseen by the Department of Constitutional Affairs but is otherwise separate from the executive functions of the state apparatus. Specifically, cases will be heard by the High Court with regard to England and Wales, the element of the court system specifically charged with hearing civil cases of this type. Generally criminal offences, such as corruption, are prosecuted by a number of prosecuting authorities, depending on the nature and seriousness of the offence. Disciplinary measures against individual contracting officers are the responsibility of individual contracting authorities.

Some important public procurement is carried out in the devolved regional administrations of Scotland, Northern Ireland and Wales, as well as in procurement offices in counties, municipal public procurement offices, and offices of groups of municipalities. The legal basis for these units varies, as the pattern of distribution of functions is complex and there is overlapping between various bodies controlled by central and local governments. Bodies that play some part in the interpretation of procurement policy at the regional level include the devolved administrations in the three home countries other than England, which have a statutory basis; the Improvement and Development Agency for Local Government; and the Regional Centres of Excellence for Procurement to which regional groups of local authorities contribute. The relationships involved are complex and not precisely defined in hierarchical terms. In general however, the sub-national bodies are concerned with providing guidance for the application of the overall UK procurement policies and of the law within their specific field of operation. Ultimately, their interpretations of policy and legislation are highly dependant upon the lead given by the national body, which is OGC PPD. 
The United Kingdom's central procurement structure is complex, embodying a compromise between a centrally-driven, hierarchical approach and a federal/devolved approach, and reflects the complexity of relationships between the central, regional and local arms of public administration. However, this means that it has the flexibility and responsiveness inherent in a part-federated approach. At the same time, the central lead is given by the most significant central procurement body, the OGC, which provides a firm central focus for procurement policy close to the centre of government and represents the United Kingdom in the relevant discussions with international partners. Sub-national bodies are able to concentrate on interpreting policy within the specific context of their field of operation, and on tailoring it to their respective needs. 